\title{
Cell mediated immunity toward kidney cells : an experimental study in dogs
}

Citation for published version (APA):

Vegt, P. A. (1983). Cell mediated immunity toward kidney cells : an experimental study in dogs. [Doctoral Thesis, Maastricht University]. Rijksuniversiteit Limburg. https://doi.org/10.26481/dis.19831006pv

Document status and date:

Published: 01/01/1983

DOI:

10.26481/dis.19831006pv

Document Version:

Publisher's PDF, also known as Version of record

\section{Please check the document version of this publication:}

- A submitted manuscript is the version of the article upon submission and before peer-review. There can be important differences between the submitted version and the official published version of record.

People interested in the research are advised to contact the author for the final version of the publication, or visit the DOI to the publisher's website.

- The final author version and the galley proof are versions of the publication after peer review.

- The final published version features the final layout of the paper including the volume, issue and page numbers.

Link to publication

\footnotetext{
General rights rights.

- You may freely distribute the URL identifying the publication in the public portal. please follow below link for the End User Agreement:

www.umlib.nl/taverne-license

Take down policy

If you believe that this document breaches copyright please contact us at:

repository@maastrichtuniversity.nl

providing details and we will investigate your claim.
}

Copyright and moral rights for the publications made accessible in the public portal are retained by the authors and/or other copyright owners and it is a condition of accessing publications that users recognise and abide by the legal requirements associated with these

- Users may download and print one copy of any publication from the public portal for the purpose of private study or research.

- You may not further distribute the material or use it for any profit-making activity or commercial gain

If the publication is distributed under the terms of Article $25 \mathrm{fa}$ of the Dutch Copyright Act, indicated by the "Taverne" license above, 
CELL MEDIATED IMMUNITY TOWARD KIDNEY CELLS

An experimental study in dogs 



\section{CELL MEDIATED IMMUNITY TOWARD KIDNEY CELLS An experimental study in dogs}

\section{PROEFSCHRIFT}

Ter verkrijging van de graad van doctor in de geneeskunde aan de Rijksuniversiteit te Maastricht, op gezag van de Rector Magnificus Prof.Dr. H.C. Hemker, volgens besluit van het College van Dekanen, in het openbaar te verdedigen

op donderdag 6 oktober 1983 te klokke 16.00 uur.

door

Paul Alexander Vegt, geboren te Zoetermeer. 
Promotores: Prof. Dr. J. Jeekel

Prof. Dr. J.M. Greep

Co-promotor: Dr. W.A. Buurman

Referenten: Prof. Dr. R.A.P. Koene

Dr. J.P. van Hooff

Zet-en drukwerk: Krips Repro Meppel

This work has been executed as part of the research program organ and tissue transplantation of the research theme 'Immunology and Oncology', in the surgical immunological laboratory, head Dr. W. A. Buturman, department of surgery, University of Limburg, Maastricht, The Netherlands.

Part of this work was supported by the Nier Stichting Nederland (Dutch Kidney Foundation), Grant No. C 81.297.

Financial support for the publication of this thesis was received from: Sandoz B.V., Uden;

N.V. Verenigde Bedrijven Nutricia, Zoetermeer. 
To my parents

To Bearriz 



\section{Contents}

Preface

Chapter 1 Immunological aspects of allograft rejection

1.1 General introduction 13

$\begin{array}{ll}\text { 1.2 Immune processes involved in allograft rejection } & 14\end{array}$

$\begin{array}{ll}\text { Cellular immunity and allograft rejection } & 14\end{array}$

Humoral immunity and allograft rejection $\quad 15$

1.3 The influence of MHC and non-MHC antigens on allograft rejection 16

$\begin{array}{ll}\text { Major histocompatibility antigens } & 16\end{array}$

Minor histocompatibility antigens $\quad 16$

$\begin{array}{ll}\text { Major histocompatibility antigens of the dog } & 17\end{array}$

$\begin{array}{ll}\text { Minor histocompatibility systems of the dog } & 18\end{array}$

$\begin{array}{ll}1.4 \text { Immunosuppression } & 18\end{array}$

$\begin{array}{ll}\text { Non-specific immunosuppression } & 19\end{array}$

Donor specific immunosuppression $\quad 21$

$\begin{array}{lll}1.5 & \text { References } & 22\end{array}$

Chapter 2 Immunological monitoring $\quad 27$

$\begin{array}{lll}2.1 & \text { Introduction } & 27\end{array}$

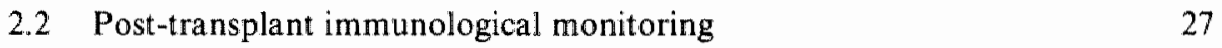

$\begin{array}{ll}\text { Post-transplant monitoring of non-specific immune reactions } & 27\end{array}$

Post-transplant monitoring of donor specific immune reactions 28

2.3 In vitro studies on the involvement of non-lymphoild antigens in graft $\begin{array}{ll}\text { rejection } & 29\end{array}$

Non-lymphoïd cells as stimulators for T lymphocytes $\quad 29$

Non-lymphoïd cells as targets for cytotoxic T lymphocytes 30

2.4 References 31

Chapter 3 Introduction to the experiments 33

3.1 Rationale of the experiments 33

3.2 Kidney epithelial cell culture $\quad 35$

Harvesting of the kidney $\quad 35$

Trypsinization of the kidney $\quad 35$ 
Chapter 4 Cell mediated cytotoxicity toward canine kidney epithelial cells

4.1 Introduction

4.2 Materials and Methods

Kidney cells

Cytotoxicity assays

Monolayers

4.3 Results

4.4 Discussion

4.5 Summary 46

Acknowledgements

4.6 References

Chapter 5 Lymphocyte stimulation by canine kidney cells

5.1 Introduction

5.2 Materials and Methods

Animals

Leucocyte cell suspensions

Kidney cells

Anti-F VIII immunolluorescence

MLC and MKLCs

5.3 Results

Identification of cultured kidney epithelial cells

Lymphocyte stimulation by cultured kidney epithelial cells

Genetic control of the MKLC

5.4 Discussion

5.5 Summary

Acknowledgements

5.6 References

Chapter 6 Cellular cytotoxicity generated in a canine mixed kidney lymphocyte cell culture

6.1 Introduction

6.2 Materials and Methods

Leucocytes

Kidney epithelial cells

Mixed cell cultures and cytotoxic assays 
6.3 Results and Discussion

6.4 Summary

Acknowledgements

6.5 References

Chapter 7 Cellular reactivity after transplantation

7.1 Introduction

7.2 Materials and Methods

Animals

68

Preparation of leucocytes

68

In vitro generation of cytotoxic $T$ cells

Assay for lymphocyte mediated cytotoxicity

Preparation of leucocyte monolayers

69

Immuno adsorption on leucocyte monolayers

69

Kidney epithelial cell culture

Operation

Thoracic duct drainage

7.3 Results

Adsorption of CTL and their precursors

Detection of cytotoxicity during a first set renal allograft rejection episode

7.4 Discussion

7.5 Summary

Acknowledgements

7.6 References

Chapter 8 Discussion of the experiments and concluding remarks

8.1 Cell mediated cytotoxicity toward canine kidney epithelial cells

8.2 Lymphocyte stimulation by canine kidney cells

8.3 Cellular cytotoxicity generated in a canine mixed kidney lymphocyte cell culture

8.4 Cellular reactivity after transplantation

Summary

Samenvatting

Slotwoord 



\section{Preface}

Although haemodialysis is a life saving treatment for patients witla end stage renal failure, kidney transplantation is accepted as the treatment of choice in such patients. A successful kid ney transplantation is not only a life saving procedure, it can give fulll rehabilitation to normal life and is less expensive than dialysis. Rehabilitation to normal life was demonstrated at the latest Transplant Olympic Games, where about 200 bearers of a functional kidney graft showed good sport performance. Technical failures of kidney transplantation are rare complications and graft rejection is still the main cause of failure of a kidney transplant. To achieve a successful transplantation. there are many problems to be solved in respect to the rejection of foreign tissue.

The major approaches to reduce the detrimental effects of allograft rejection are:

- The appropriate selection of donor and recipient. Matching for transplantation antigens will reduce the number of foreign antigens presented to the recipient of a graft to which rejection can be initiated.

- Adequate detection of rejection by immunological monitoring. Crossmatches between the donor and the recipient will detect antibodies toward donor antigens. The presence of these antibodies indicates a state of presensitization of the recipient, which in a number of cases has been reported to be responsible for acute rejection of the graft.

Monitoring of the recipient has to be continued after transplantation by evaluating kidney function and immune function of the recipient. Changes in these parameters will permit the detection of a possible rejection episode. This has to be followed by adequate anti-rejection treatment, to prevent loss of the graft.

- Anti-rejection treatment. A great number of agents have been tested for suppression of the immune reactivity of the recipient. The drugs mostly applied is the combination of azathioprine and corticosteroids, which are already 20 years in use in kidney transplantation. A few years ago cyclosporin-A has been introduced as a powerful immunosuppressive agent, since this drug is not used in combination with corticosteroilds this new treatment lacks the serious side effects of long term corticosteroild administration. Anti-lymphocyte serum is used for the treatment of rejection episodes, however, the use of anti-lymphocyte serum has not yet been generally used in clinical transplantation.

Total histocompatibility of both major and minor antigen systems between donor and recipient can only be achieved in the rare cases of a transplantation between identical twins. In all other cases a transplantation will be performed between related or non-related donor recipient combinations which are not fully identical in respect of 
their histocompatibility antigens. In elinical transplantation the selection of donor and recipient is most commonly based on matching for antigens encoded for by the Major Histocompatibility Complex ( $\mathrm{MHC}$ ). The importance of this complex, which is located on the short arm of chromosome 6 has been shown by the excellent survival rates of kidneys transplanted between siblings which are identical for the $\mathrm{MHC}$ antigens (van Rood 1967). There is clear evidence that also non-MHC antigens are involved in the rejection of kidney grafts, since kidney graft rejection has been reported in a number of transplantations between HLA identical siblings, despite immunosuppressive therapy (Salamon 1976, Cheigh 1977). This implies that other antigens, not encoded for by the MHC complex are also involved in kidney graft rejection. These non-MHC antigens, or so called Minor Histocompatibility Antigens are already known for a long time in the animal model, especially in the mouse. Their role in kidney graft rejection is not yet defined. The best studied non-M HC antigens in the human are the various granulocyte antigens (Lalezari 1980. Thompson 1980).

The first report on the involvement of antibodies to non-M HC antigens in relation to kidney transplantation in man, has been published by Paul. (Paul 1979 $)$. He found a specific humoral response toward endothelial antigens after kidney transplantation. The presence of these anti-endothelial antibodies after transplantation during rejection of the graft and the absence of these antibodies in kidney grafts removed for non-immunological reasons, does suggest that these antigens do play an important role in kidney graft rejection (Paul $1979^{\mathrm{b}}$ ). The reports on the involvement of endothelial antigens in human transplantation as well as in vitro studies on non-M $\mathrm{MC}$ antigens were a motive for the study of these antigens present on kidney cells.

In this thesis cell mediated immunity toward canine kidney epithelial cells in kidney transplantation was investigated to detect the possible role of antigens on kidney epithelial cells. An in vitro model has been developed, in which reactivity toward these kidney epithelial cells could be studied.

The experiments presented in this thesis had the following objectives:

- The development of an in vitro model with canine kidney epithelial cells in which cellular reactions toward these cells can be studied.

- To investigate whether in vitro stimulation of lymphocytes by kidney epithelial cells is possible.

-..- To study the nature of antigens on kidney epithelial cells which are recognized by cytotoxic T lymphocytes.

- To evaluate cell mediated cytotoxicity toward kidney epithelial cells as targets in monitoring cellular rejection after transplantation. 


\section{Chapter 1}

\section{Immunological aspects of allograft rejection}

\subsection{General introduction}

The dog has been one of the first animals in which kidney transplantations have been performed. Already in 1905 Carrel reported experimental kidney transplantations in the dog. He developed the surgical technique for anastomosing the renal vessels, which is essentially still in use today. The transplantation model was used in a study of vascular surgery, Carrel stated: "We shall study here only the technique employed to obtain a good union of the often very small vessels' (Carrel 1905). Ullman was the first who reported auto-and allograft kidney transplantations in dogs, not as an attempt to study the vascular problems but to investigate the phenomenon of organ transplantation (Ullman 1902). Ullman, neither Carrel mentioned the problem of rejection and they attributed their failures of longterm functioning of the grafts to technical problems.

Rejection of transplanted kidneys was not defined until 1923 when Williamson published the first pictures of a rejected kid ney and mentioned the difference between a utografted and allografted kidneys (Williamson 1923). He was the first to consider the possibility of tissue matching and he suggested that there might be a method of testing the recipients serum toward donor tissue.

It was Gorer in 1936, whose classical work on the immunology of tumor allograft rejection described the serological methods to detect tissue antigens (Gorer 1936). He identified histocompatibility antigens, which were defined as red cell bloodgroups. Matching for these antigens had a favourable effect on the survival of the transplanted tumor. He stated that isoantigenic factors are genetically determined and those present in the grafted tissue and absent in the host are capable of elicting a response which results in the destruction of the graft (Gorer 1937).

The recognition that the destruction of a graft was an immunological phenomenon, was established by Sir Peter Medawar, who studied the fate of skin grafts of burned patients during World War II. Medawar discovered that second set allografts were rejected more rapidly than first set allografts and that the accelerated rejection of at second set allograft was specific, since it pertained only to the grafts obtained from the same donor as the first set (Medawar 1944).

Medawar observed in mice that this sensitization of allografts could also be ind uced by intradermal injections of leucocytes from the skin donor. This observation led to the conclusion that leucocytes are involved in the process of graft rejection. An experimental proof that allograft rejection was mediated by a cellular reaction has been provided by Mitchinson. He performed his classical adoptive transfer experi- 
ments, in which he showed that the sensitized state of the recipient rejecting a tumor graft can be transferred to a new recipient with lymphoid cells but not with serum (Mitchinson 1953).

\subsection{Immune processes involved in allograft rejection}

Burnet proposed the concept of the clonal selection theory and a general theory of the nature of immunity; "I shall always regard the differentiation between self and non-self as crucial to all immunological theory" was stated by Burnet (Burnet 1959). It became obvious that a proportion of lymphocytes was committed to react toward specific alloantigens, without prior sensitization toward these antigens.

\section{Cellular immunity and allograft rejection}

Miller and Good described the central role of the thymus in cellular immunity. They demonstrated that either neonatal thymectomy or thymectomy of adult mice followed by X-ray irradiation and bone marrow reconstitution leads to the abrogation of the capacity to reject foreign tissues (Miller 1961, Good 1962). The effect of these procedures was dependent on the depletion of so called thymus related area's of the peripheral lymph nodes and spleen. It was not until the late sixties, that the different functions of $\mathrm{T}$ and $\mathrm{B}$ lymphocytes were recognized. The primitive lymphoid cells were shown to originate from the bone marrow and differentiate into two small lymphocyte populations: Tlymphocytes, maturated under influence of the thymus, responsible for cell mediated immunity and B lymphocytes, the bursa dependent lymphocytes, which are responsible for producing antibodies. The Bursa of Fabricius is a lymphoid organ in chickens, which controls the maturation of $B$ lymphocytes. The equivalent of the bursa in man is not clearly defined but there are indications that the haemopoietic tissues itself are the places where B lymphocytes are maturating.

Gowans established the central role of lymphocytes for both types of immune responses with labeling studies of circulating lymphocytes. He labeled lymphocytes and demonstrated a pool of recirculating lymphocytes, which pass from the blood into the lymph nodes and spleen and back to the blood by the main lymphatic chamnel, the thoracic duct (Gowans 1964).

The differentiation between self and non-self is based on recognition of cell surface antigens by $\mathbb{T}$ and $B$ cells of the host. The receptor for antigens on the surface of $B$ lymphocytes is an immunoglobulin molecule. $B$ cells respond to foreign antigens with the production of antibodies, with an idiotype identical to the receptor present on the surface of the $B$ cell before stimulation. $T$ cell recognition leads to the induction of helper T cells, which can either collaborate with $B$ cells resulting in the proliferation of $B$ cells into antibody producing plasma cells or to the activation of $T$ killer cells, which results in a direct killing of the allogeneic, or virus infected target cells. The mechanism of T cell recognition is still under extensive study. T cells can recognize products of 
self and foreign MHC products, the latter being a major barrier in organ transplantation. T cells recognize antigens together with receptor molecules which are controlled by the $\mathrm{MHC}$ complex. For example virus infected target cells are only killed by T cells which were sensitized by virus infected cells carrying the same MHC products as the target cells. This is known as $\mathrm{MHC}$ restriction of T cell recognition (Zinkernagel 1974).

The two different mechanisms of $T$ cell recognition: Allogeneic and altered self recognition raised the question whether $T$ cell activation is caused by different receptors present on the $T$ cells or that one receptor may be responsible for both reactions. Matzinger proposed that $\mathrm{T}$ cells recognize neither antigen, nor $\mathrm{MHC}$ molecules alone but rather the molecular complexes composed of the two (Matzinger 1981). This is in contrast with the two receptor theory as described by Lafferty, who postulated that lymphocyte activation requires the presentation of both antigen and an inductive MHC molecule to the responder T cell (Lafferty 1980). This second signal, by way of the inductive $\mathrm{MHC}$ molecule, is also able to bind antigen to its surface and is also called co-stimulator. Lafferty proposed that specificity of this reaction is expressed at the level of the co-stimulator. This mechanism is known as dual recognition and suggests the presence of two separate receptors, one for antigens as well as one for MHC products (Janeway 1976).

\section{Humoral immunity and allograft rejection.}

Allograft rejection is mediated by both humoral and cellular mechanisms. "The precise action of the cells involved in antibody mediated rejection is still largely unknown. The occurrence of circulating antibodies after renal transplantation is now well established. In a number of patients, antibodies directed toward $T$ or B cells can be detected before transplantation. This can be a result of previous immunisations by blood transfusions, pregnancies or unknown origin. A high incidence of hyperacute rejection has been reported in cases where these circulating antibodies do crossreact with the donor lymphocytes (Kissmeyer 1966, Patel 1969). This type of rejection occurs within a few minutes to hours after transplantation, resulting in interstitial haemorrhage of the kidney, which becomes swollen, blue and motted. There is no treatment for this hyperacute rejection and it has to be followed by nefrectomy.

Clear evidence is a vailable that not all positive crossmatches do result in a hyperacute rejection, crossmatches against donor $B$ lymphocytes are mostly not associated with hyperacute rejection (Ettenger 1979, Jeannet 1981). Moreover there are reports on the enchancing effect of positive B cell crossmatches (d'Apice 1979, Jeannet 1980).

A graft induced antibody mediated reaction can lead to chronic or late acute rejection. $I g \mathrm{M}$ and $\mathrm{C}_{3}$ deposits on the basement membrane of the glomerulus of the transplanted kidney have been reported in the cases of chronic rejection (Porter 1968). It has been suggested that this is caused by a reaction of circulating antibody with the antigens present on the capillary basement membrane of the graft. 


\subsection{The influence of $\mathrm{MHC}$ and non- $\mathrm{MHC}$ antigens on allograft rejection}

\section{Major histocompatibility antigens}

The use of inbred strains of mice made it possible to investigate the murine major histocompatibility system ( $\mathrm{H}-2$ system). Snell introduced the term histocompatibility antigens for those antigens, which are involved in rejection (Snell 1948).

The investigation of the H-2 system in the mouse has been an important step for elucidating the Human Leucocyte Antigen (HLA) system in man. Amos and Ceppellini established the role of HLA as the strongest antigen system in man by skin graft experiments (Amos 1969, Ceppellini 1969).

HLA mismatched siblings had a significant shorter survival time of their skin allografts than HLA matched sibling donor recipient combinations. Kidney transplantation between HLA-A and HLA-B matched, related donor recipient combinations has been proven to have a good graft prognosis (van Rood 1967). Application of the HLA-A and B typing (serological defined SD or Class 1 antigens) to unrelated cadaver donor situations has been less promising in respect to graft survival. It is now well established that matching for class 1 antigens results in an overall improvement of $10-15 \%$ of 1 year cadaver graft survival. This overall result can be separated over two groups of cadaver kid ney recipients in respect to the graft survival time. If anti-leucocyte antibodies are detected in the recipients, due to previous immunisations like pregnancies or blood transfusions, there is more improvement in graft survival when donor and recipient are matched for the HLA-A and HLA-B locus (van Hooff 1976, Opelz 1977). This implicates that in the group without circulating antibodies (the so called non-responders) there is no important improvement in graft survival after matching for the HLA-A and HLA-B antigens. Despite the small effect on graft survival, there is a great effect on patient survival in the class I identical donor recipient combinations, compared to class I mismatched combinations (van Rood 1977).

Bach suggested in 1970 that Mixed Leucocyte Culture (MLC) non-responsiveness (matching for class II antigens) might be more important than matching for class I antigens (Bach 1970). This was confirmed by Cochrum, who found in retrospective studies more significant influence on graft survival for class II antigens than for class I antigens (Cochrum 1973). The first prospective study on this subject was performed in the Rhesus monkey model by van Es, who clearly demonstrated that prospective matching for class Il antigens outweighted matching for class I antigens (van Es 1977).

\section{Minor histocompatibility antigens}

Since skin and kidney graft rejection and graft versus host disease occurs in HLA identical sibling allografts, there is no doubt that also non-HLA antigens are involved in rejection. The difference between $\mathrm{MHC}$ antigens and non-MHC antigens was first 
described in mice by Counce. Using inbred strains of mice he described differences in the intensity of allograft rejection of tumors between mice carrying the first three identified histocompatibility loci $\mathrm{H}-1, \mathrm{H}-2$ and $\mathrm{H}-3$ (Counce 1956). He transplanted tumor cells between $\mathrm{C} 57 \mathrm{Bl} / 10\left(\mathrm{H}-2^{b}\right.$ to $\mathrm{B} 10 . \mathrm{D} 2\left(\mathrm{H}-2^{d}\right)$ which is across the $\mathrm{H}-2$ barrier and to the B 10-LP which only differed at the H-3 locus from C57B1/10. A transplant of 1000 tumor cells/mouse across the $\mathrm{H}-2$ histocompatibility barrier was rejecied by all mice. Grafting 1000 tumor cells across the $\mathrm{H}-3$ barrier from $\mathrm{C} 57 \mathrm{BI} /$ to $\mathrm{B} 10 \mathrm{LP}$ mice killed $90 \%$ of the recipients.

This indicates that the $\mathrm{H}-3$ barrier was much weaker and not able to induce rejection of the C57B $/ 10$ tumor cells. This distinction between a "strong" H-2 locus and a 'weak' non $\mathrm{H}-2$ locus was confirmed by skin graft experiments. Skin grafts across an $\mathrm{H}-2$ barrier were rejected in an average of 8.5 days, whereas skin grafts across an H-3 (or H-1) barrier survived for about 24 days.

Based on these results Counce defined a strong Histocompatibility locus as: 'A locus such that a difference between donor and host at this locus will prevent the progressive growth of nearly all tumor homotransplants and cause the rapid rejection of skin homografts'. A weak Histocompatibility locus was defined as 'a locus such that a difference between donor and host at this locus will permit the progressive growth of various tumor homotransplants and fail to cause a rapid rejection of skin homografts' (Counce 1956).

Since all other loci discovered so far, were weak by this definition, they were called non $\mathrm{H}-2$ loci. Except differences in rejection of allografts, also other fundamental differences between $\mathrm{H}-2$ and non $\mathrm{H}-2$ loci have been described. This led to the designation of $\mathrm{H}-2$ as the Major Histocompatibility Complex ( $\mathrm{MHC}$ ) and the non $\mathrm{H}-2$ loci as Minor Histocompatibility loci (MIH) in mice.

The major histocompatibility complex can be subdivided in three classes of genes, which all have specific functions in control of the different molecules involved in immunological responsiveness. Class I genes control the former serological or SD antigens and are encoded for by the K, D and L loci of the $\mathrm{H}-2$ complex in the mouse, which code for 40-45,000 mol. weight molecules associated with $\mathrm{B} 2 \mathrm{~m}$ at the cell surface. The Class $1 \mathrm{I}$ genes, $\mathrm{I}^{\mathrm{a}}$ genes include antigens which are responsible for the control of MLC stimulation, ly mphocyte activating determinants (lad); Class II genes code for a $32.000 \mathrm{~mol}$. weight and $\mathbb{B}$ molecules $(28.000 \mathrm{~mol}$. weight) associated as dimer at the cell surface. Finally the Class 111 genes are controlling the complement component $\mathrm{C} 4$. The $\mathrm{MHC}$ of the mouse can be extrapolated with great simmilarity to other species. It has been described for many mammalian species such as the dog. Rhesus monkey, Guinea pig, rabbit and man.

\section{Major histocompatibility antigens of the dog}

The canine $\mathrm{MHC}$ complex is analogous to that of man. There are three series of serological detectable (class I) antigens, called DLA-A, DLA-B and DLA-C. Vriesendorp showed a great linkage disequilibrum between the alleles of the three serological 
detectable series of antigens (Vriesendorp 1973). Mixed leucocyte reactions have been performed in the dog since 1968 (Serre 1968). After the initiall report on mixed leucocyte stimulation in the dog many different techniques have been used for mixed leucocyte cultures (Gluckmann 1973, Grosse-Wilde 1973, v. Tweel 1974, Bach 1975). The locus responsible for this mixed leucocyte reaction is called DLA-D and is situated closely near the SD loci (v. Tweel 1974). There is a great linkage disequilibrum between the class 1 loci and the DLA-D locus in the dog (Grosse-Wilde 1975).

\section{Minor histocompatibility systems of the dog}

The red bloodgroup system in the dog can be considered as a minor histocompatibility system. Transfusions across bloodgroup antigen barriers do result in a shorter red cell survival time in some cases. Swisher studied the bloodgroup systems in dogs and differentiated at least seven major bloodgroups coded for A to G (Swisher 1961). Only the bloodgroup $\mathrm{A}$ antigens ind uce powerf $u$ l haemolysin reactions when transfused into recipients carrying anti-bloodgroup $\mathrm{A}$ antibodies. These reactions were not observed when transfusions were performed across the other bloodgroup antigen barriers. Transfusion reactions are only seen when the recipient is pre-sensitized, since natural antibodies to red cell antigens are not present in the $d o g$, first transfusions never lead to the well known transfusion reaction with tremor, fever and emesis. In contrast with man transfusion reactions in dogs are never fatal. Since the first transfusion never provokes a reaction, the bloodgroup system in dogs does not have much practical implication in veterinarian practice.

The detection of minor histocompatibility antigens which are not present on red blood cells is more complex, due to the problems of producing antisera against such antigens. To study these minor antigens, grafting experiments between DLA matched littermates and DLA mismatched dogs have to be performed. Westbroek showed with small bowel transplantation experiments that indeed non-MHC antigens are involved in the rejection of small bowel tissue in the dog (Westbroek 1970).

Bijnen found that the mean survival time (MST) of kidney transplantations between SD and LD identical mongrel dog combinations is significant shorter than the survival of kidney transplantations between DLA identical, non-sibling beagle combinations. The MST of kidney transplantations between DLA identical and one haplotype mismatched littermate beagles did not differ significant. He concluded that the cumulative effect of non-DLA histocompatibility systems is comparable with the DLA histocompatibility system and might even be underestimated (Bijnen 1978).

\subsection{Immunosuppression}

A great number of agents and treatments have been tested for suppression of the immune system of the recipient in order to obtain long time graft survival. The immune response of the recipient can be modified by either non-specific immunosuppression or donor specific immunosuppression. 
Anti-lymphocyte serum: Woodruff showed an inhibitory effect of anti-lymphocyte serum (ALS) on cell mediated immunity of the recipient. The injection of lymphocytes, thymocytes or other lymphoild cells into a non-compatible animalleads to the production of a serum, which gives a profound depression of the number of circulating T cells when injected into the donor of the lymphoild cells (Woodruff 1963). It has been reported that ALS is a very potent immunosuppressive agent in most animal species (Starzl 1967). Its clinical use is still a controversial subject (Najarian 1976 , Sheil 1973, Thomas 1977). Recently Toledo-Pereyra showed that ALS is a good adjuvant therapeutic agent for the treatment of recurrent rejection episodes in clinical cadaver kidney transplantation (Toledo-Pereyra 1982). A prospective randomized trial to compare the effectiveness of rabbit anti-thymocyte globulin (RATG) in the treatment of acute renal graft rejection with high dose prednisone treatment has been performed by Hoitsma (Hoitsma 1982). In this study the treatment of acute rejections in the cadaver donor situation using the high potency RATG as the single agent, was an effective and safe method which is steroid sparing and as effective as high dose prednison treatment. One of the main problems of ALS in clinical transplantation is the lack of standarisation of production of ALS. The newest development in this field is the use of monoclonal antibodies prowided by hybridomas using the technique of Kohler (Kohler 1975) which can be directed toward T cells or subsets of T cells. The OKT 3, a monoclonal antibody has been used clinically in Boston, so far without very spectacular results (Cosimi 1981).

Total lymphoïd irradiation: Total lymphoïd irradiation (TLI) has potentiats for use in clinical transplantation. Slavin reported prolongation of skin and heart allograft survival in rodents treated with TLI (Slavin 1978). The combination of TLI and the administration of donor bonemarrow resulted in permanent chimeras. In these chimeras indefinite graft survival was obtained without graft versus host disease. Such chimeras have also been produced in mongrel dogs (Slavin 1979). Total lymphoïd irradiation is effective for its general immunosuppressive effect as well as its ability to specific tolerance with bonemarrow transplantation. Najarian showed in a clinical trial that the immunosuppressive effects of pre-transplant TLI are diminished when transplantation is delayed (Najarian 1982). A synergistic effect op post-transplant TLI and immunosuppression with low dose anti-lymphocyte globulin or cyclosporinA has been reported by Bentley (Bentley 1983).

Blood transfusions: The benificial effect of pre-transplant blood transfusions is now generally accepted. The mechanism by which blood transfusions lead to prolonged graft survival is still not understood. Third party blood transfusions are correlated with prolonged graft survival in clinical as well as experimental transplantation. The blood transfusion effect can be considered as a non-specific immunosuppression of the recipient. Keown has suggested that damaged red cells present in transfused blood may impair mononuclear phagocytic cell function, resulting in a non-specific sup- 
pression of the immune response (Keown 1979). Van der Linden showed a benificial effect of whole blood transfusions given in combination with immunosuppression (van der Linden 1982). A graft survival prolonging effect of per-operative blood transfusions was obtained in non-related donor recipient combinations in the dog (van der Linden 1982). This observation might have great implications for clinical transplantation because per-operative blood transfusions exclude the danger of pre-transplant sensitization of the recipient by circulating antibodies induced after transfusions, which may cross-react with the donor kidney antigens. Williams confirmed the benificial effect of blood transfusions given per-operatively in the cadlaver renal allograft siltuation. She observed a change in one year graft survival from $34 \%$ with no transfusions to $85 \%$ one year graft survival after two units of whole blood given during operation (Williams 1980). A multicentre analysis performed by Opelz with data of 65 North American centers however could not show any beneficial effect of per-operatively given blood transfusions (Opelz 1981).

Interesting data for the discussion on the mechanism of the blood transfusion effect on allograft rejection have been presented by Jeekel. He found that blood transfusions given pre-operatively to the donor modified the immune response toward the grafted kidneys in rats, dogs and in man. In the rat a third party blood transfusion to the donor reduced graft survival, whereas recipient leucocytes injected into the donor had a prolonging effect on the allografted kidney. In dogs the enhancing effect of a per-operative given blood transfusion could be abrogated with a third party blood transfusion given to the donor. In a retrospective study in man a significant impaired graft survival has been observed if the donor was not transfused (Jeekel 1980). This result has been confirmed by Frisk, who found that the positive effect of donor transfusion seems to be of the same magnitude as that registered from pre-operative blood transfusions given to the recipient in his centre (Frisk 1983).

Pharmocological immunosuppression: The most widely used immunosuppressive agents are azathioprine and corticosteroïds. Azathioprine (a derivative of 6 mercaptopurine developed for the treatment of malignancies) showed to be a strong immunosuppressive agent and it has been the basic immunosuppressive drug since the early sixties (Calne 1961). The combination of azathioprine and corticosteroilds for pharmacological immunosuppression dates from 1963, when Murray showed reasonable prolongation of cadaver donor kidney grafts (Murray 1963).

Many other drugs have been investigated since then, one showed the combination of immunosuppression and relative safety: Cyclosporin-A, a fungus metabolite has shown to have marked immunosuppressive properties (Borel 1976). It has firstly been demonstrated to prolong skin grafts in mice and heterotopic cardiac allografts in rats (Kostakis 1977). This agent has now been used in several clinical situations and it has the great advantage that it gives profound immunosuppressive action, probably acting on the early phase of $T$ cell differentiation, without the serious side effects of steroids like Cushing's syndrom, induction of diabetes and bone necrosis. The main drawback of Cyclosporin-A however is its nefrotoxicity (Calne 1978).

The clinical results with Cyclosporin- $\mathrm{A}$ are very promising. Calne reported an 
actual surviwal time of $86 \%$ one year graft survival in the cadaver donor situation compared with the normal $55 \%$ one year survival in his centre with conventional immunosuppression (Calne 1981).

\section{Donor specific immunosuppression}

Immunological tolerance was produced by Billingham in the 1950 s. He injected mouse fetuses in utero with tissue homogenates of foreign strains and induced a complete tolerance toward antigens of the injected strain (Billingham 1953).

Immunological enhancement: Snell defined enhancement as: the enhanced or prolonged growth of allografts, due to the presence in the graft recipient of alloantibody directed against the alloantigens of the donor (Snell 1970). The possible mechanisms of kidney graft enhancement are still unknown.

Jeekel showed that the administration of donor cells prior to skin grafting in mice resulted in prolonged acceptance of the skin graft, provided that more than 2 injections were given (active enhancement). A similar effect was observed when serum of mice, which were treated with i.v. injections of donor tissues, was transferred to recipients of skins from the same donor as the one used for sensitisation of the serum donor (passive enhancement) (Jeekel 1971).

Fabre clearly demonstrated in rats that the injections of kidney donor antigens to the recipient before transplantation can provoke an accelerated rejection as well as a prolonged acceptance of the kidney graft. The effect of such treatment varies, depending on dose, time and route of administration of the antigens (Fabre 1974).

Injection of anti-donor antibodies into the recipient before transplantation can result into passive enhancement as well as, hyperacute rejection (Koene 1973). Hyperacute rejection is probably mediated by complement components activated by antibodies that have attached to the graft. It has been demonstrated that in the case of passive enhancement the specific $\mathrm{IgG}$ and cytotoxic $\mathrm{T}$ cell responses are deficient while reactivity in MLR is preserved (Kostakis 1977).

The interactions of cellular and humoral responses leading to enhancement are still largely unknown. A blockage of the interaction of helper T cells which are necessary for the interaction of $\operatorname{lgG}$ and cytotoxic $T$ cells is supposed to be responsible for the enhancing effect. Immunological enhancement has no place in clinicall transplantation due to practical problems of inducing enhancement in the cadaver donor situation as well as difficulties in extrapolating studies from inbred animals to man.

Donor specific blood transfusions: In 1978 the San Francisco group initiated a deliberate donor specific blood transfusion (DST) protocol for living related kidney transplantation (Salvatierra 1980). The positiwe effect of this protocol has been confirmed by other groups (Takahashi 1982, Leivestad 1982). Whether the prolongation of graft survival in living non-related donor recipient combinations depends on selection or may be attributed to the induction of specific unresponsiveness is still not 
clear. Leivestad found in some patients a donor specific reduced MLC after DST and often an association of increased CML reactivety toward donor cells was observed (Leivestad 1982). The mechanism of this change in MLC and CML reactivety and their influence on graft survival has to be further examined.

\subsection{References}

Amos DB, Seigler HF, Southworth JG, Ward FE. Skin graft rejection between subjects genotyped for HL-A. Trarnspiant Proc 1969: 1: 342.

d'Apice AJF. Tait BD. Improved surviwal and function of renal transplants with positive B cell crossmatches. Transplantation 1979: 27: 324.

Bach JF", Debray-Sachs M, Crosmier J, Kreis H, Dormont. Correlation between mixed lymphocyte culture performed before renal transplantation and kidney function. Clin exp Immunol 1970; 6:821.

Bach $\mathrm{ML}_{\mathrm{s}}$ Bach FH, Rasmus W. Burkholder PM, Dufek J, Kahn D. DL-A LD matching: Its prognostic walue for kidney allograft survival. Transplant Proc 1975,7:423.

Bentley FR, Sulherland DER, Rynasiewicz $\mathbb{N}$, Najarian $J S$. Synergistic effect of post-transplant total Iymphoid irradiation and pharmacologic inmunosuppression with low-dose antilymphocyte globulin or cyclosporine on prolongation of rat heart allograft survival. Transplant Proc 1983; 15: 671.

Bijnen AB. Donor selection for renal transplantation. Thesis, Erasmus University, Rottendam 1978 .

Billingham RE. Brent L, Medawar PB. Actively acquired tolerance of foreign cells. Nature 1953; 4379: 603.

Borel JF. Comparative study of in witro and in viwo drug effects on cell-mediated cytotoxicity. Immunology $1976 ; 31: 631$.

Burnet FM. The clonal selection theory of acquired immunity. Cambridge Uniwersity Press 1959.

Calne RY. Inhibition of the rejection of renal homografts in dogs by purine analogues. Transplant Bull $1961 ; 28: 445$

Calne RY, White DJG, Evans DB et al. Cyclosporin A in patients receiving renal allografts from cadaver donors. Lancet 1978;2:1323.

Calne RY, White DJG, Evans DBet al. Cyclosporin A in cadaveric organ transplantation. Br Med J 198:; 282: 934 .

Ceppellini R, Mattinz PL, Scuddeller G et all. Experimental allotransplantation in man 11 . The role of A A2 and B antigens. Transplant Proc 1969; 1: 390.

Carrel A, Guthrie CC. Functions of a transplanted kidney. Science 1905; 22: 473.

Cheigh JS, Chami J, Stenzel KH, Riggio RR, Saal S, Mouradian JA, Forino M, Stubensord WT, Rubin AL. Renal transplantation between HLA identical siblings; comparison with transplants from HLA semi-identicall related donors. New Eng J Med 1977; 296:1030.

Cochrum KC, Perkins AA, Payne RO, Kountz SL, Belzer FO. The correlation of MLC wilh graft survival. Transplant Proe 1973; 5: 391 .

Cosimi AB, Burton RC, Colvin RB et al. Treatment of acute renal allograft rejection with OKT3 monoclonal antibody. Transplantation 1981; $32: 535$

Counce S. Smith P., Barth R. Snell GD. Strong and weak histocompatibility gene differences in mice and their role in the rejection of homografts of tumors and skin. Amn Surg 1956 144: 198.

Es AA van, Marquet $\mathbb{R} L$, Vreeswijk $W$ van, Tank $B$, Balner $H$. Influence of matching for RhLA (SD) antigens. and of mixed lymphocyte reactivity on allograft survival in unrelated rhesus monkeys. Tramsplant Pros 1977; 9: 257.

Ettenger $\mathrm{RB}$, Uitenbogat $\mathrm{CH}$, Pennisi AJ. Longterm cadaver allograft surviwal in the recipient with a positive B lymphocyte cross match. Transplantation $1979 ; 27: 315$.

Fabre IW, Morrisi. PJ. Passive enhancement of homozygous renal allografts in the rat. Transplantation 1974: 18: 429 .

Frisk B, Berglin E, Brygner H. Transfused cadaver küdney donors and graft survival. Transplantation 1983; 35: 352 . 


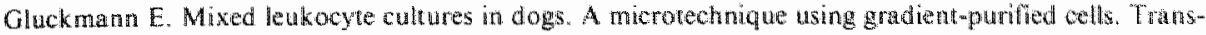
plantation 1973; $5: 642$.

Good RA, Dalmasso AP. Martinez $C$ et al. The role of the thymus in development of inmunologic capacity in rabbits and mice. J Exp Med $1962 ; 116: 773$.

Gorer $\mathrm{PA}$. The detection of antigenic differences in mouse ery hurocytes by the enploynent of immune sera. Brit J Exp Pathol 1936; 17: 42 .

Gorer $P$ A. The genetic and antigenetic basis of tumour transplantation. J Pathol Bacteriol 1937; 44: 691 . Gowans JL, Knight EJ. The route of re-circulation of lymphocytes in the rat. Proc Roy Soc London 1964 : 159: 257.

Grosse-Wilde H. Baumann P, Netzel B, Kolb HJ, Wank R. Mempel W, Albert ED. One way non-stinulation in MLC related to DL-A homozygosity. Transplant Proc 1973; $5: 1567$.

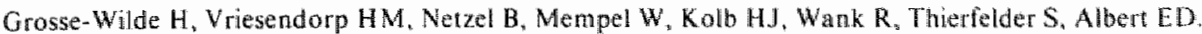
Immunogenetics of sewen LD alleles of the DL-A complex in unongrels, beagles and labradors. Transplant Proc 1975; $7: 159$.

Hoitsma AJ, Reekers P, Kreeftemberg. IG et al. Treatment of acute rejection of cadaveric renal allografts ransplantation with rabbit antithymocyte globullin. T1982; 33:12.

Hooff JP van. The relative importance of HLA matching in kidney iransplantation. Thesis Leiden University 1976.

Janeway $C A$, Wigzell $H$, Binz $H$. Two different $V_{\mathrm{h}}$ Gene products make up the $T$ cell receptors. Scand J Immunol 1976; 5: 993.

Jeamet M, Benzonana $\mathrm{G}$, Atni 1. Donor-specific B and Tlymphocyte antibodies and kidney graft survival. Transplantation 1981; 31: 160

Jeannet M, Vassali P. Hufschmid MF. Enhancement of human kidney allografts by cold $B$ lymphocyte cytotoxins. Transplantation 1980; 29: 174.

Jeekel J. Immunological enhancement of skin allo- and heterografts. Thesis. Erasmus University, Routerdam. 1971.

Jeekel $J$. van der Linden $C J_{4}$ Vegt PA et al. Modification of kidney graft survival in dog and man by pre-operative transfusion to the donor. Proc EDTA 1980; 17:457.

Keown PA, Descamps B. Improved renal allograft surviwal after bloodtransfusion: A non-specific, erythrocyte-mediated immunoregulatory process?. Lancet 1979; 1: 20.

Kissmeyer-Nielsen F, Olsen S, Peterson VP, Fjeldborg O. Hyperacute rejection of kidney allografts, associated with pre-existing humoral antibodies against donor cells. Lancet 1966;2: 662.

Koene RAP, Gerlag PGG, Hage man JFHM, van Haelst UJH, Wijdeveld PGAB. Hyperacute rejection of skin allografts in the mouse by the ad ministration of allo antibody and rabbit complement. $J$ Inmunol 1973: $1111: 520$.

Kohler G. Milstein C. Continuous cultures of fused cells secreting antibody of predefined specificity. Nature 1975; 256: 495.

Kostakü, AJ, White DJG, Calne RY. Prolongation of the rat heart allograft survival by cyclosporin A IRCS Med Sci 1977; 5: 280 .

Lafferty KJ. Immunogenecity of foreign tissues. Transplantation 1980; 29: 179.

Lalezari P. Organ-specific and systemic alloantigens: Interrelationships and biologic implications. Transplant Froc $1980 ; 12: 12$

Leivestad $T$. Flatmark $A_{n}$ Hirschberg $H$ et al. Effect of pre transplant donor-specific transfusions in renal tramsplantation. Transplant Proc 1982; 14: 370.

Linden CJ van der, Buurman WA, Vegt PA, Greep JM, Jeekel J. Effect of bloodtransfusions on canine renal allograft survival. Transplantation $1982 ; 33: 400$.

Matzinger P. A one-receptor view of T-cell behaviour. Nature 1981; 292: 497.

Medawar PB. The behaviour and fate of skin autografts and skin homografts in rabbits. J Anat 1944; 78 : 176.

Miller JFAP. Immunological function of the thymus. Lancet 1961;2:748.

Mitchinson NA. Passive transfer of transplantation immunity. Nattre 1953; 4345: 267

Murray JE, Merrill JP, Harrison JH, Wilson RE, Dammin GJ. Prolonged survival of human kidney homografts by immunosuppressive drug therapy. New Eng J Med 1963: 268: 1315. 
Najarian JE, Simmons RL, Condie R A al. Seven years experience with antilymphoblast globulin for renal transplantation from cadate donors. Ann Surg $1976 ; 184: 352$.

Najarian IS, Ferguson RM. Sutherland DER, et al Fractionated cotal lymphoid irradiation as preoperative immunosuppression in hight risk renal transplantation. Ann Surg 1982; 196: 442.

Opelz $G_{1}$ "Terasek $P$. Enhancement of kidney graft survival by blood transfusions. Transplant Proc 1977; 9: 121.

Opelz G, Terasaki PI. Importance of preoperative (not per-operative) transfusions for cadaver kidney transplants. Tramsplatitation $1981 ; 31$ : 106.

Patel R, Terasaki PI. Significance of the positive crossmatch test in kidney transplantation. New Eng J Med 1969:280:735.

Paul LC. Clans HJF, Leendert MSc. Aceelerated rejection of a renal allograft associated with pre-transplantation antibodies directed against donor antigens on endothelium and monocytes. New Eng.J Med 1979, 300: 1258 .

Paul LC, Es LA wan, Rood JJ van et al. Antibodies directed against antigens on the endothelium of peritubular capillaries in patients with rejecting renal allografts. Tramsplantation 1979;27; 175 .

Porter KA, Andres GA, Galder Wet al. Humat renal transplants; immunofluorescent and immunolerritin studies. Laboratory Investigation 1968: 18: 159 .

Rood JJ van, Leeuwen $\mathrm{A}$ wan, Brining JW. The relewance of leucocyte antigens for allogeneic renal transplantation. J Clin Path 1967; 20: 504.

Rood JJ vam, Leeuwen A van, Persijn GG et al. HLA compatibility in clinical transplantation. Transplant Proc 1977: 1:459.

Rynasiewice JJ, Sutherland DER, Kawahara $K$, Najarian JS. Total lymphoid irradiation: Critical timing and combination with cyclosporin $A$ for immunosuppression in at heart allograft model. J Surg Res 1981; 30: 365.

Sala mon لR, Godfrey AM, Russel RB, Brown P. Festenstein H. Rejection of HLA identical related kidney transpiants. Tissue Antigens 1976; 8: 233.

Salvatierra $O$, Vincenti $F_{3}$ Amend $W$ et al. Deliberate donor specific blood transfusions prior to living related transplantation. A new approach. Ann Surg 1980; 192:543.

Serre A, Clot J. Les tests d'histocompatibilite chez le chien en vue de l'experimentation des greffes d'organes. Rev Fr Etud Clin Bül $1968: 13: 1019$.

Sheil AGR, Mears D, Johnson JR et al. Antilymphocyte globulin in patients with remal allografts from cadaweric donors. Late results of a controlled trial. Lancet $1973 ; 2: 227$.

Slavin S, Reit 2 B, Bieber CP et al. Transplantation tolle rance in ad ult rats using total lymphoid irradiation: permanent survival of skin, heart and marrow allografts. J Exp Med 1978; $147 ; 700$.

Slavin $S$, Gottlieb $M_{n}$ Strober $S$ et al. Transplantation of bone marrow in outbred dogs without graft-versushost disease using total lymphoid irradiation. Transplantation 1979; $27 ; 139$.

Snell GD. Immunologic entrancement. Surg Gynec Obstet 1970; 130: 1109.

Snell OD. Methods for the study of histocompatibility genes. J Genetics 1948; $49: 87$.

StarzI TE, Marchioro TL, Porter KA et al. The use of heterologous antilymphoid agents in canine renal and liver homotransplantation and in human renal homotransplantation. Surg Gynec Obstet 1967; 124: 301 .

Strober S, Slavin S, Gottlieb MS et al. Allograft tolerance after total lymphoid irradiation (TLI). Immunol Rev 1979; 46:87.

Swisher $S_{4}$ Young LE. The blood grouping systems of dogs. Physiol Rev 1961; $41: 495$.

Takahashi I, Otsubo $O$. Nishimura M et al. Prolonged graft survival by donor specific blood transfusions (DSBT). Tramsplant Proc 1982; 14:367.

Thomas $F$, Thomas J, Flora R et al. Effect of antilymphocyte globulin potency on surviwal of cadaver renal transplants. Lancet $1977 ; 2: 671$.

Thompson $\ S$, Overlin V, Severson CD et al. Demonstration of gra nulocyte, monocyte, and endothelial cell antigens by double fuorochromatic microcytotoxicity testing. Transplant Proc 1980; 12: 26.

Toledo-Pereyra LH, Mittal VK, Baskin S. et al. Non steroid treatment of rejection in kidney transplantation. A new approach including long-term treatment of rejection with antilymphoblast globulin in a high risk population. Transplantation $1982 ; 33 ; 325$. 
Ullmann E. Experimentelle Nierentransplantation. Wien Klin Woehenschr 1902; 15, 281: $70 \%$.

Vriesendorp HM. Major histocompatibility complex of the dog. Thesis, Erasmus University thoterdam 1973.

Westbroek. DL, Rothengatter C, Vriesendorp HM, van Rood JJ. Histocompatibilty and heterotopic segmental small bowel allograft survival in dogs. Eur Surg Res 1970; 2: 401 .

Williams KA, Ting A, French ME, Oliver D, Morris. PJ. Per-operative blood-1rarusfusions improve cadaveric renal-allograft survival in non-transfused recipients. A prospective controlled elinical trial. Lancet 1980; 1: 1104.

Williamson. CS. Some observations on the length of survival and function of homogenous kidney transplants. Preliminary report. 3 Urol 1923; 10:275.

Woodruff MFA, Anderson NA. Effect of lymphocyte depletion by thoracicduct fistula and administration of anti-1ymphocytic serum on the survival of skin homografts in rats. Nature 1963; $200: 702$.

Zinkernagel RM, Doherty PC. Restriction of in witro T-oell mediated cytotoxicity in lymphocytic choriomeningitis within a syngeneic or semiallogeneic system. Nature (London) 1974; 248: 701 . 



\section{Chapter 2}

\section{Immunological monitoring}

\subsection{Introduction}

The complexity of interactions between the allografted kidney and the immune system of the recipient involves humoral and cellular immune reactions in the recipient. For the interpretation of the clinical events and for optimal therapeutic support it is essential that the host immune system can be evaluated in time. This is the base of immunological monitoring.

The main goals of immunological monitoring are to avoid hyperacute rejection due to pre-sensitization of the recipient toward donor antigens by crossmatching donor and recipient before transplantation and the detection of changes in the immune status of the recipient after transplantation. To fulfil these aims pre-transplant and post-transplant monitoring assays have been developed. A short review of the posttransplant immunological monitoring assays will now be given.

\subsection{Post-transplant immunological monitoring}

The determination of early changes in the recipient immune status facilitates the initiation of early thera peutic steps before irreversible da mage to the graft occurs due to the rejection process. From this point of view it is essential for clinical transplantation that the data obtained from the post-transplant monitoring assays are available within one or two days after onset of the tests. The assays for determining the immune reactions may detect reactions directed toward donor antigens or measure non-specific changes in the immune system of the recipient.

\section{Post-transplant monitoring of non-specific immune reactions}

The detection of rejection episodes by means of non-donor specific monitoring can be done by determinations of lymphocyte subpopulations, changes in lymphocyte responsiveness and detection of an inflammatory reaction in the graft.

Cosimi investigated the relative ratios of the different $T$ cell subsets. Using monoclonal antibodies to helper/inducer $\mathrm{T}$ cells $\left(\mathrm{OKT}_{4}\right)$ and suppressor/ cytotoxic $\mathrm{T}$ cells $\left(O K T_{8}\right)$ he determined the $T_{4}: T_{8}$ ratio at different intervals after transplantation and observed a reversed $T_{4}: T_{8}$ ratio in a pre-rejection and rejection state (Cosimi 1981).

Guttmann used flow cytometry for stud ying lymphocyte subsets after transplanta- 
tion and found an increase in blast cells and lymphocytes with IgG and IgM prior and during rejection episodes (Guttmann 1983).

Lymphocyte responsiveness toward mitogens has also been used to study a possible correlation with rejection. Some investigators found a correlation between acute rejection and increase of $\mathrm{PHA}$ responsive T cells whereas the Con A reactive lymphocytes were not increased (Haisch 1981). This could not be confirmed by other investigators (Toledo-Pereyra 1981). Inflammatory reactions in the graft were studied by Hayry, who performed fine needle aspiration biopsies and cytologic studies. He was able to diagnose and predict the in situ inflammatory response of rejection (Häyry 1981).

\section{Post-transplant monitoring of donor specific immune reactions}

Humoral as well as cellular immune assays have been evaluated for correlation with rejection. Complement dependent cytotoxicity has been noted by several investigators to correla te with the onset of rejection. Soulillou found that donor specific anti-B cell reactivity was correllated with bad graft prognosis (Soulillou 1981). Stiller used a ${ }^{5} \mathrm{Cr}$ release assay with donor specific complement dependent cytotoxicity and found a good correlation between donor specific complement dependent cytotoxicity and acute graft rejection (Stiller 1981).

Antibody dependent cell mediated cytotoxicity (ADCC) has been evaluated by many investigators. There are many conflicting data on the outcome of such assays in correlation with rejection. ADCC is not yet used as a clinical tool for the diagnosis of rejection after transplantation.

Direct lymphocyte mediated cytotoxicity: Stiller used a LMC assay in which peripheral blood lymphocytes of the recipient after transplantation were incubated directly with the donor target cells without prior in vitro stimulation. In this assay with an incubation time of effector and target cells up to 18 hours he observed that LMC correlated temporally and significantly with acute rejection. In 26 kidney transplant recipients, he found that $\mathrm{LMC}$ toward donor cell targets was correlated positively with rejection in 41 out of 45 rejection episodes. A positive LMC without signs of rejection was detected in only in 4 out of 29 cases (Stiller 1976). Thomas found a similar correlation, however his assays were less sensitive and correlated with a later phase of the acute rejection (Thomas 1981).

Indirect cell mediated cytotoxicity: An assay which gives important information of the recipients immune status in regard to non-responsiveness to donor antigens is the indirect cell mediated cytotoxicity test. With this assay lymphocyte mediated cytotoxicity toward donor target cells was determined after in vitro stimulation of the peripheral blood lymphocytes of the recipient with donor antigens. Thomas found an anti-donor LMC unresponsiveness after a successful kidney transplantation (Thomas 1981). This LMC unresponsiveness has aiso been reported by Goulmy, who found that $70 \%$ of the recipients accepting their grafts showed donor specific LMC unresponsiveness, with a normal reactivity toward non-donor incompatible cells (Goulmy 1981). 
These reported correlations of the indirect lymphocyte mediated cytotoxicity tests with the clinical rejection episodes are of great importance for the study of the mechanism of kidney graft rejection. Concerning the clinical value of these tests in predicting allograft rejection, one is confrontated with the fact that it takes about a week before the data of these tests are available.

The only lymphocyte mediated cytotoxicity assay which could be clinical useful in this respect is the direct lymphocyte mediated cytotoxicity test as used by Stiller because this test can be performed within 24 hours.

\subsection{In vitro studies on the involvement of non-lymphoid antigens in graft rejection}

The cellular component of allograft rejection has been studied in vitro by two different models. The mixed lymphocyte culture (MLC) is used to study the ind uction of allograft rejection and the cell mediated lympholysis (CML) for studying the efferent phase of allograft rejection (Bach 1973). The antigens which are involved in MLC and CML are encoded for by the HLA system. In clinical transplantation it is well established that also non-HLA antigens are involved in kidney graft rejection. The antigenic properties of non-lymphoid tissues in respect to their stimulating properties for lymphocyte proliferation as well as their use as targets for cytotoxic lymphocytes have had limited attention so far.

\section{Non-lymphoïd cells as stimulators for T lymphocytes}

The first reports on lymphocyte stimulation by non-lymphoid cells are from Ginsberg, who cultured rat lymph node cells together with monolayers of embryonic mouse cells. They observed transformation of the rat lymphoild cells, which became cytotoxic for the cell types present in the stimulating monolayer. After this report many different cell types have been cultured with allogeneïc cells. Post embryonic skin and dog endothelial cells (Vetto 1972) showed lymphocyte stimulation in allogeneic stimulator responder combinations. The analysis of the $\mathrm{MHC}$ complex in the pig made it possible to obtain kidney cell lines from pigs with defined SD and LD phenotypes. Daniel showed that lymphocyte stimulation by pig kidney cells was independent of SD differences between stimulator and responder, but it was necessary that LD differences existed between the pig used as source of the kidney cells and the responder lymphocytes (Daniel 1975).

Pawelec studied lymphocyte proliferation by non-lymphoid porcine tissue cells extensively. He found that allogeneic liver and kidney cells were strong lymphocyte stimulators and the characteristics of these cultures were similar to those observed in mixed leucocyte cultures. He was not able to stimulate lymphocytes in mixed endothelial leucocyte and mixed fibroblast leucocyte cultures (Pawelec 1979). Main and Mashimo showed that under suitable conditions also rat kidney cells could stimulate allogeneïc lymphocytes (Main 1975, Mashimo 1976). 
Interesting experiments hawe been performed with skin leucocyte cultures. Hirschberg showed that lymphocytes reactive to allogeneic skin cells recognized other antigens than lymphocytes stimulated by allogeneïc leucocytes (Hirschberg 1975). This implicates the existence of skin specific antigens. However, anti-H LA antibodies reacting toward the relevant donor inhibited the lymphocyte response toward skin stimulator cells, which suggests that the skin specific antigens are closely related to MHC antigens.

Tanaka performed primary and secondary miked skin leucocyte reactions (MSLR) and found a maximum proliferation response on day six of the primary culture, whereas restimulation of the MSLR showed a optimal response after two days (Tanaka 1979). This is comparable with the primary and secondary MLR and they stated that the mixed skin leucocyte reaction is a true immunological phenomenon.

Vascular end othelial cells are important in kidney transplantation because they are the cells which have the first and most direct contact with the recipient immune system. This cell type has been studied extensively in vitro. Canine endothelial cells have been reported to stimulate allogeneïc lymphocytes (Groenewegen 1983). In the human, Hirschberg showed lymphocyte stimulation by end othelial cells (Hirschberg 1974). Moen performed PLT tests with human endothelial cells, derived from umbilical cords, and showed significant stimulation on day 2 and day 3 of the secondary mixed endothelial lewcocyte culture (Moen 1980). This implicates that class 11 products are present on endothelial cells, which confirmed studies with Dr anti-sera.

The studies described above suggest that non-lymphoïd cells are strong stimulators for allogeneïc lymphocytes in different species. One essential question remains unanswered; are the non-lymphoild stimulator cell fractions contamined with lymphoild cells. In most reports freshly prepared non-lymphoïd cells have been used as stimulators. As mentioned by Hart this procedure does not exclude the possible contamination of the stimulator cells with dendritic cells (Hart 1981). Dendritic cells are known to be very potent stimulators and they can be responsible for lymphocyte stimulation even in very low numbers. In the studies concerning lymphocyte reactivity toward canine kidney epithelial cells we paid special attention to exclude this possibility.

\section{Non-lymphoild cells as targets for cytotoxic $T$ lymphocytes}

It has always been stated that cytotoxicity was mainly directed toward class I antigens. HLA-A, HLA-B or HLA-Cantigens in man or $\mathrm{H}-2 \mathrm{~K}$ and $\mathrm{H}-2 \mathrm{D}$ antigens in the mouse. In mice evidence arose that also the I region determinants could serve as targets in cell mediated cytotoxicity tests, if Con A stimulated leucocytes were used as targets. Tyler investigated epidermal specific cytotoxicity from CTL lines maintained in vitro for 9 months. He found that CTL recognized epidermal specific alloantigen (EPA-1) in a $\mathrm{H}-2$ restricted way (Tyler 1982). These EPA-I directed CTL clones can be an interesting reagent to study the influence of tissue specific antigens in graft rejection through the use of adoptive transfer experiments. Recently cytotoxicity toward non-class I antigens has been observed. Feighery investigated the cell mediat- 
ed lympholysis assay with monocytes as target cells. They found that cytotoxicity correlated with HLA-D. Cold target experiments with monocytes confirmed that HLA-D region products were recognized by the cytotoxic lymphocytes (Feighery 1979). This was later confirmed by other investigators (Johnson 1980). It is clear from these observations that indeed a non-class I directed cell mediated cytotoxicity exists. However, the role of this non-class I cytotoxicity in kidney transplantation still has to be investigated. In the experiments described in this thesis non- $\mathrm{MHC}$ directed cytotoxicity toward canine kidney cells has been studied.

\subsection{References}

Bach FH, Segall M, Zier KS, Sondel PM. Alter BJ, Bach ML. Cell mediated immunity: separation of cells involved in recognitive and destructive phases. Science 1973; 180; 403.

Cosimi $\mathrm{AB}$, Burton $\mathrm{RC}$, Colvin $\mathrm{RB}$ et al. Treatment of acute renal allograft rejection with OKT3 monoclonal antibody. Transplantation 1981; 32: 535 .

Daniel MR. Edwards MJ. Interaction of pig lymphocytes with allogeneic kidney cells in witro. Brit I Exp Path 1975; 56: 349 .

Feighery C, Stastny P. HLA-D region associated determinants serve as targets for human cell-mediated lysis. J Exp Med 1979; 149: 485.

Goulmy E, Persijn G, Blokland E et al. Cell mediated lympholysis studies in renal allograft recipients. Transplantation 1981; 31: 210 .

Groenewegen G, Buurman WA, van der Linden C., Jeunhomme GMAA, Kootstra G. Cellular cytotoxicity against canine end othel lall cells. Analysis of determinants recognized by CTL. Tissue Antigens 1983; 21: $1 \llbracket 4$.

Guttmann RD, Poulsen RS. Fluorescence activated cell sorter analysis of lymphocyte subsets after renal iransplantation. Transplant Proc 1983; 15: 1160.

Haisch CE, Thomas FT, Thomas JM. Differential role of T-lymphocyte subsets in human acute allograft rejection. Transplant Proc 1981; 13: 1746.

Hart DNJ, Fabre JW. Major histocompatibility complex antigens in rat kidney, ureter and bladder. Transplantation 1981:31:318.

Häyry $P$, von Willebrand. E. Transplant aspiration cytology in diagnostic evaluation of renal allografts. Transplant Proc 1981; 13: 1575.

Hirschberg H, Evensen SA. Hendriksen T. Thorsby E. Stimulation of human lymphocytes by allogeneic endothelial cells in vitro. Tissue Antigens 1974: 4: 257.

Hirschberg $\mathrm{H}$, Thors by $\mathbb{E}$. Lymphocyle activating allowantigens on human epidermal cells. Tissue Antigens $1975 ; 6: 183$.

Johnson HE. Human B-blast specific target determinants in CML: a methodological study. Tissue Antigens 1980; 15: 189 .

Man RK, Jones MJ. Birnbaum J et al. Mixed culture response of lymphocytes to dissociated kidney cells. Transplantation 1975; $20: 92$.

Mashima S, Sakai A, Ochiai T et al. The mixed kidney cell lymphocyte reaction in rats. Tissue Antigens $1976 ; 7 ; 291$.

Moen T. Moen M. Thersby E. HLA-D region products are expressed in endothelial cells: Detection by primed lymphocyte lyping. Tissue Antigens $1980 ; 15 ; 112$.

Pawele G, Davies HFFS, Steele C, White D, Brons G. Stimulation of lymphocyte proliferation in vitro by cultured non-lymphoid tissue cells which do not express la like antigen. Transplant Proc 1979; 11: 1095.

Soulitiou JP, de Mouzon-Cambon A. Dubois C et al. Immunological studies of eluates of 83 rejected kidneys. Transplantation $198 \| ; 32: 368$. 
Stiller CR, Keown PA, Sinclair NR ef al. Interpretation of clinical events in the light of measured immune responsers. Tramsplant Proc 1981; 13: 1628.

Stiller CP, Sinclati $\mathbb{N} R$, Abrahams $S$ el al. Anti-donor immune responses in prediction of transplamt rejection. New Eng J Med 1976; 294:978.

Tanaka $\mathbf{S}$. Sakai A. Stimulation of al logeneic lymphocytes by skin epidermal cells in the rat. Transplantation 1979; 27 : 194.

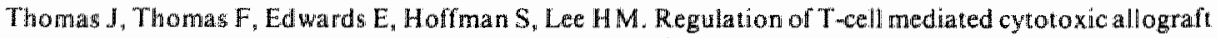
response in thuman transplant recipients. Transplant Proc 1981;13:1594.

Toledo-Pereyra LH, Wohlman MH, Gordon DA, Palutke M. Immunological monitoring after cadawer kidney transplartation. Lack of correlation between in witro and clinical evidence for rejection. Transplant Proc 1981; $\| 3: 1747$.

Tyler JD. Steinmuller D. Establishment of cytolytic T lymphocyte clones to epidermal alloantigens. Epa-1. Transplantation $1982 ; 34: 140$.

Vetto RM, Burger DR. Endothelial cell stimulation of allogeneic lymphocytes "Transplantation 1972; 14: 652 . 


\section{Chapter 3}

\section{Introduction to the experiments}

\subsection{Rationale of the experiments}

From clinical transplantation it is clear that also non-HLA antigens are involved in graft rejection. Kidney transplantation between HLA identical related donor recipients depends on continuous immunosuppression therapy and even then rejection occurs occasionally. The observations of Paul proved that a humoral reactivity toward non-lymphoid antigens present on endothelial cells correlates with renal allograft rejection (Paul 1979). The involvement of a cellular reaction toward nonlymphoid antigens in clinical transplantation has had little attention sofar. Steinmuller reported a cellular reaction toward epidermal cells in a mixed epidermal cell leucocyte culture. His study indicates the presence of non-lymphoid antigens on epidermal cells in the mouse (Steinmuller 1981).

In this study a cellular reaction toward non-lymphoid antigens and the role this reaction plays in kidney transplantation has been studied. In vitro cultured canine kidney epithelial cells were used as a model to study cell mediated immunity in the dog. Stimulating properties of antigens present on kidney cells have been reported in different species.

Main and Mashimo showed lymphocyte stimulation by kidney cells in a rat model (Main 1975, Mashimo 1976), whereas Pawelec extensively studied the stimulation of allogeneïc lymphocytes by porcine kidney cells (Pawelec 1979). Also in the dog lymphocyte stimulation by kidney cells has been reported (Lifton 1977).

These studies however do not prove, nor exclude the presence of non-lymphoid antigens on kidney cells. An important question concerns the identification of the kidney cells used. Are these cells indeed purified kidney epithelial cells, or is there a contamination with other cell types which might explain the reported results. Hart mentioned this problem and suggested that contamination of the kidney cells with low numbers of dendritic cells is responsible for the allogeneic stimulation of lymphocytes in the mixed kidney cell leucocyte cultures (Hart 1981).

We tried to develop a model in which both questions could be studied. The kidney epithelial cell culture was chosen as an in vitro model. Kidney epithelial cells have to be purified from other celltypes and have to stay in culture for some period, so they are readily available. A technique has been developed to culture canine kidney epithelial cells and to store them in liquid nitrogen.

It is of great importance to culture kid ney epithelial cells free of contamination with other cells. The kidney contains cell types like fibroblastoild cells and endothelial cells, which can be present in the in vitro culture of kidney cells. 
The possible contamination of the kidney epithelial cell culture with various cell types has been evaluated in many ways. A culture medium has been chosen to exclude the growth of fibroblasts; immunofluorescence studies were performed to identify endothelial cells in the culture system. The cell suspensions finally used were checked microscopically for the presence of lymphoid cells.

After solving these technical problems the main concern was the identification of the nature of antigens present on the cultured canine kidney epithelial cells. The question whether kid ney cells carry antigens which could be recognized by cytotoxic effector cells has been studied with in MLC generated effector cells. These cytotoxic T lymphocytes have been tested toward stimulator type kidney target cells and PHA stimulated lymphoblasts. To investigate whether CTL recognize antigens on kidney cells which are not present on lymphoid cells, adsorption and cold target inhibition studies have been performed to select different populations of Tlymphocytes directed toward target antigens.

Kidney cells are probably not only involved in the afferent phase of the rejection process. We liked to know whether they are able to ind uce a rejection reaction. The stimulator capacity of kidney cells has been studied with mixed kidney cell leucocyte cultures. These experiments are described in chapter 5 . The kinetics of the mixed kidney cell leucocyte culture have been compared with the kinetics of a mixed leucocyte culture. An interesting question was whether kidney cells were able to stimulate lymphocytes when stimulator and responder were MHC identical animals. To answer this question mixed kidney cell leucocyte cultures between closely related MHC identical dogs have been performed.

Steinmuller reported the generation of CTL in a murine mixed epidermal cell leucocyte culture (Steinmuller 1981). This observation is in contrast with the theory of immunogenecity of foreign tissues as proposed by Lafferty, in which CTL can not be generated without lymphoid cells in the stimulator cell fraction (Lafferty 1980). This question has also been studied in the canine model. Mixed kidney cell leucocyte cultures were set up in different stimulator responder ratios and the stimulated lymphocytes were tested for cytotoxicity toward PHA stimulated lymphoblasts and kidney cell targets.

The main goal of the experiments was, to investigate the usefulness of kidney cells for the determination of cell mediated immunity toward donor antigens after transplantation. A first set renal allograft rejection model in non-immunosuppressed dogs has been used to investigate CTL and their precursors after transplantation. It is an accepted hypothesis that the homing of CTL in the grafted kidney is responsible for the inconsistent results of cell mediated monitoring after transplantation. We studied whether it is possible to use kidney cells as targets to detect clones of CTL after transplantation, directed toward non-MHC antigens. The affinity of CTL and their precursors for donor antigens can be studied in vitro with aid of immunoadsorption studies during the generation of CTL.

The fourth publication describes a study on the affinity of CTL and their precursors toward donor leucocyte antigens in an in vitro study and the results have been verified 
in the in viwo model for detecting CTL and their precursors directed toward donor kidney cells after transplantation.

\subsection{Kidney epithelial cell culture}

The kidney cells, used in the experiments described in this thesis were obtained by perfusion trypsinisation of beagle kidneys. Canine kidney cells are grown in mass cultures in the RIV institute (Bilthoven, the Netherlands) for the production of viruses. The harvesting methods and culture conditions of the RIV institute were slightly modified with the generous help of Ir. A.L. van Wezel of the RIV institute, to enable a monolayer culture of canine kidney cells in tissue culture flasks. To compare immunological properties of the kidney cells and peripheral blood cells of the same dog, only one kidney was used from each dog so the animal could stay alive and be used afterwards as blood donor.

\section{Harvesting of the kidney}

Nefrectomy was performed under sterile conditions in the operating room while the dogs were under anesthesia of fentanylbase and Na-pentobarbital intravenously. After intubation, the dogs were respirated with an $\mathrm{O}_{2} / \mathrm{N}_{2} \mathrm{O}$ gas mixture. Through a midline incision the abdomen was opened and the right or left kidney was removed. Directly after removing the kidney, cold perfusion with Eurocollins solution at $4 \mathrm{C}$ started and the cooled kidney was transported under sterile conditions to a laminat flowhood.

\section{Trypsinization of the kidney}

In the laminar flowhood the Eurocollins solution was disconnected and the kidney flushed with a Na-citrate solution at $38 \mathrm{C}$ containing $0.25 \%$ trypsin. This perfusion took place during about $40-45$ minutes in which about $500-600 \mathrm{ml}$ of the trypsim solution was perfused through the kidney. During perfusion, the kidney capsula was removed to prevent an abnormal rise of intrarenal pressure due to swelling of the kidney during trypsinization. After perfusion of the kidney the ureter, pyelum and connective tissue were carefully separated from the medulla and cortex. The remaining cortex and medulla suspension was dispensed in MEM medium containing $10 \%$ new born calf serum to neutralize the trypsin. The tissue was dispersed for I minute by use of the Vibromixer and the cell suspension was drained of into a sterile bottle. The cell suspension was washed twice in MEM medium supplemented with antibiotics. Finally a standard vital stain procedure with trypan blue was performed and showed a viability count of more than $80 \%$. The kidney cells could now be used for tissue culture or stored in liquid nitrogen. 
From one kidney about $10^{9}$ viable cells were recovered. Since relatively small numbers of cells were needed for the tissue culture experiments, about $90 \%$ of the cells were stored in liquid nitrogen direct after the trypsinization and washing procedure. The kidney cells were resuspended in MEM + Hanks balanced salt solution, supplemented with 10\% heat inactivated new born calfserum in a concentration of $10^{7}$ cells $/ \mathrm{ml}$ and cooled to $0 \mathrm{C}$. This cell suspension was diluted 1:1 with MEM + 20\% DMSO, which was added slowly in about 10 minutes. Plastic ampules were filled with $2 \mathrm{ml}$ of the cell suspensions and cooled from $0 \mathrm{C}$ to $-100 \mathrm{C}$ in a programmed freezing a paratus (Cryoson, Middenbeemster, The Netherlands). After reaching - $100 \mathrm{C}$ the ampules were placed in liquid nitrogen and kept until use.

\section{Cell culture conditions}

The kidney cells were plated in plastic tissue culture flasks, $175 \mathrm{~cm}^{2}$ in a concentration of $5 \times 10^{6}$ cells per flask. Culture medium consisted of MEM + Hanks balanced salt solution, supplemented with $10 \%$ heat inactivated new born calfserum, $5 \%$ lactalbumin, $2 \mathrm{mM}$ glutamine, $100 \mathrm{lu} / \mathrm{ml}$ penicillin and $100 \mu \mathrm{g} / \mathrm{ml}$ streptomycin. This solution is further called: complete MEM medium. The cultures were set up in a humified atmosphere containing $5 \% \mathrm{CO}_{2}$ in air at $38 \mathrm{C}$. A few hours after sedimentation the cells attached to the plastic and after 4 to 5 days confluent monolayers of kidney cells were obtained. The medium was refreshed every other day and after 4 to 5 days the cells were detached from the culture flasks by removing the culture medium, washing the cell cultures in phosphate buffered saline (PBS) and incubating the monolayers with a $0.2 \%$ EDTA solution at $38 \mathrm{C}$ for about 15 minutes. EDTA was used in this procedure in order to exclude the possibility of altered antigenic properties of the cells. Poste reported that proteolytic enzymes adsorb to the cell surface and prevent the formation of glycoprotein cell coat material for as long as 24 hours (Poste 1971). After removing and washing the cells they were replated again in a concentration of $5 \times 10^{6}$ cells/flask. The medium was now changed into a D-valine MEM medium, in order to prevent the growth of fibroblasts in the kidney cell culture. In D-valine MEM medium, L-valine is substituted for D-valine and only those cells containing D-aminoacid oxidase can convert the D-ammo acid into its essential L-enantiomer. Since fibroblasts lack the D-aminoacid oxidase enzym, this medium does select out the overgrowth of fibroblasts (Gilbert 1975).

\section{Identification of kidney epithelial cells}

Tissue cultures are easily contaminated with other cells than those which have to be studied. The kidney posesses a number of different cell types, therefore it is difficult to determine exactly which cells remain in culture. Gilbert studied tissue cultures of 
kidney cells grown in D-valine medium, he found high lewels of produced alkaline phosphatase and the renal pattern of lactate dehydrogenase. He concluded from this study that the in D-valine medium selected kidney epithelial cells are of renal tubular origin and that they retained their differentiated functions (Gilbert 1977).

The presence of passenger leucocytes and dendritic cells in the kidney cell suspension used, has carefully been excluded by means of microscopical examination. It is well established that dendritic cells are potent stimulators (Steinman 1978). Since dendritic cells do not proliferate in vitro, we used only kid ney cells which were at least 15 days in culture. This excludes the presence of dendritic cells in kid ney cell cultures.

Vascular endothelial cells are also present in the kidney and could contaminate, the initial culture. We discovered that canine endothelial cells did not survive in MEM medium. It was therefore unlikely that contamination with end othelial cells occurred. To further exclude their presence, immunofluorescence of the kidney cell cultures has been performed. The kidney cells were cultured on microscope slides with Lab-Tab 4808 tissue culture chambers. Cells were fixed in methanol $+5 \%$ acetic acid at $-20 \mathrm{C}$, rinsed with PBS and incubated for 45 minutes at $37 \mathrm{C}$ with rabbit anti-dog anti-F VIII related anti-serum. This highly purified anti-F VIIl related antigen serum was obtained by absorption of rabbit anti-dog anti-F VIII serum with serum proteins of dogs with Von Willebrands disease (kindly provided by Dr. J. Bouma, department of haematology, State University of Utrecht). The slides were washed extensively for 15 minutes in PBS and subsequently incubated with a goat anti-rabbit IgG-FITC conjugate for 45 minutes at $4 \mathrm{C}$. The slides were washed and mounted with glycerol PBS. Displacement of the coverslips was prevented by colorless nail polish painted around the edges of the coverslip. The preparations were examined immediately or stored at $-20 \mathrm{C}$. Fluorescence with anti-canine F VIII serum revealed that cultured canine kidney cells did not show any significant fluorescence whereas cultured canine venous endothelial cells obtained by collagenase digestion of the vena cava showed strong specific intra cellular fluorescence. We conclude that the cultured kidney cells are epithelial in appearance and not contaminated with fibroblasts, dendritic cells or endothelial cells.

\subsection{References}

Gilbert SF, Migeon BR. D-valine as a selective agent for normal human and rodent epithelial cells in culture. Cell 1975; $5: 11$.

Gilbert SF, Migeon BR. Renal enzymes in kidney cells selected by D-waline nedium. J Cell Physiol 1977; 92: 161 .

Hart DNJ, Fabre JW. Major histocompatibility complex antigens in tat kidney, ureter and bladder.

Transplantation 1981: $31: 318$.

Lafferty KJ. Immunogenecity of foreign tissues. Transplantation $1980 ; 29: 179$

Lifton $J$, de Wolf $W C$, Wilcox $C$, Miller J. Regulatory mechanism in Iymphocyte activation. Acad press New York 1977: 400.

Main RK, Jones MJ, Birnbaum J et all. Mixed culture response of lymphocytes to dissociated kidney cells. Transplantation 1975; 20: 92. 
Mashmo $\$$, Sakai $A$, Ochial T el al. The mixed kidney cell lymphocye reacion in rats. Tissue Antigens $1976 ; 7: 291$.

Paul LC. Chas HJF, Leendent MSC. Accelerated rejection of a renal allograft associated with pretransplantation antbodies directed against donor antigens on endothelium and monocytes. $\mathrm{N}$ Eng $J$ Med 1979: $300: 1258$.

Pawed $G$, Davies HFFS, Stele C, White D. Brons $G$. Stimulation of lymphocyte proliferation in vitro by cultured non-lymphoid tissue cells which do not express la like antigen. Transplant Proc 1979-11:1095.

Poste $G$. Tissue dissociation with proleclytic enzymes. Adsorption ard activity of enzynzes at the cell surface. Exp Cell Res 197\%, 65:359.

Steinman RM. Wiumer MD. Lymphoid dendritic cells are potent stimulators of the primary mixed leucocyte reaction in mice. Proc Nath Acad Sci $1978 ; 75: 5132$.

Steinmuller D. Tyler JD, Dawid CS. Cell mediated cytotoxicity to non-MHC alloantigens on mouse epidermal cells. J Immuno 1981; $126: 1747$. 


\section{Chapter 4}

\section{Cell mediated cytotoxicity toward canine kidney epithelial cells}

\subsection{Introduction}

The cellular component of allograft rejection can be studied in vitro by two different models. The mixed lymphocyte culture (MLC) can be used to study the induction of allograft rejection. Cell mediated lympholysis represents the destructive or efferent phase of allograft rejection (Bach 1973). Lightbody (1971) developed the system of cell mediated lympholysis, using PHA stimulated lymphoblasts as sensitive targets for effector cells generated in MLC. Most studies concerning specificity and genetics of the cell mediated lympholysis have been performed with PHA stimulated lymphoblasts as targets. The antigens involved in these two in vitro models are class I and class II antigens.

In the human the known class I and class II antigens as detected by these in vitro assays areencoded for by the human leucocyte antigen system (HLA), the HLA-A-B-C and HLA-D/DR loci of the major histocompatibility complex (Shaw 1980). In clinical transplantation the selection of donor and recipient is based on histocompatibility testing, using antibodies directed against class I and class II antigens of the HLA system. It has been observed however that kidney transplantation between HLA identical siblings depends on continuous immunosuppression therapy and that even then rejection occurs occasionally. Moreover, a definite graft survival has been reported to occur in unrelated recipients of HLA mismatched kidneys. These observations indicate that non-HLA antigens are also involved in kidney transplantation. So far, little attention has been paid to the influence of non-HLA antigens on graft survival. Recently however, data have become available about the possible role of non-HLA antigens in graft rejection (Claas 1980, Paul 1979).

The present experiments were conducted to study the cell mediated cytotoxicity toward antigens present on canine kidney cells and to study CTLs directed toward PHA stimulated lymphoblast targets and kidney cell targets.

\subsection{Materials and Methods}

\section{Kidney cells}

Kidney cells were obtained by unilateral nephrectomy of beagles from our closely bred beagle colony. After unilateral nephrectomy, the animals were kept alive and used as blood donors for MLC and cell mediated cytotoxicity tests. This procedure 
permitted us to compare antigens present on kidney cells and on leucocytes from the same dog. The removed kidney was ex vivo perfused with a $0.25 \%$ trypsin solution for 40 min at $37 \mathrm{C}$. After tremoving the capsula a cell suspension of cortex and medulla cells was obtained, the pyelum was not dissociated. Dissociated kidney cells were cultured in minimal essential medium plus Hanks balanced salt solution with $10 \%$ heat inactivated new born calf serum, $5 \%$ lactalbumin, $2 \mathrm{~m} \mathrm{M}$ glutamine and antibiotics. Cell cultures of kidney cells from dogs with different haplotypes were established as monolayer cultures or stored at $-196 \mathrm{C}$.

All cells were morphologically epithelial in appearance. Immunofluorescence with rabbit anti-dog factor VIII, highly purified with serum of dogs with the Von Willebrand's disease, has been performed to exclude the presence of endothelial cells. Positive anti-factor VIII immunofluorescence indicated the presence of endothelial cells (Jaffe 1973). The primary cultured kidney cells as well as the second and third passage cells showed no immunofluorescence whereas cultured canine endothelial cells showed the characteristic intracellular immunofluorescence with this anti-factor VIIll reagent.

Although the cultured cells were virtually free of fibroblastoid cells, experiments have been performed to ascertain their epithelial origin. The kidney cells resisted culturing in a D-valine minimal essential medium as has been reported for epithellial cells. This indicated furthermore that the cultured cells did not contain fibroblastoid cells, since these cells are not able to convert D-valine medium (Gilbert 1975). It is therefore concluded that our cultured kidney cells contained neither fibroblasts nor endothelial cells.

\section{Cytotoxicity assays}

Effector cells were generated by incubation of $10^{7}$ responder leucocytes and $10^{7}$ irradiated stimulator leucocytes (2500 rad) of one haplotype mismatched beagles. Cultures were set up in $20 \mathrm{ml}$ of R PMI 1640 supplemented with $10 \%$ heat inactivated pooled dog serum, $2 \mathrm{mM}$ glutamine and antibiotics.

After 6 days of incubation at $37 \mathrm{C}$, with $5 \% \mathrm{CO}_{2}$ in a humified atmosphere, cultures were assayed for cytotoxicity. Cellular cytotoxicity was assayed with ${ }^{5 /} \mathrm{Cr}$-labeled target cells. Cultured kidney cells and PHA stimulated lymphoblasts have been labeled with 100 to $200 \mu \mathrm{Ci}$ of ${ }^{51} \mathrm{Cr}\left(\mathrm{Na}_{2}{ }^{51} \mathrm{CrO}_{4}\right.$; Amersham, England) in $0.1 \mathrm{ml}$ containing $10^{6}$ target cells at $37 \mathrm{C}$ for $45 \mathrm{~min}$. For all experiments $2.5 \times 10^{351} \mathrm{Cr}$-labeled target cells per well have been used. The number of effector cells are given in the tables and figures, resulting in effector to target cell ratios ranging from $20: 1$ to $80: 1$. Cytotoxic assays were performed in round bottom microtiter plates in six-fold. After $6 \mathrm{~h}$ of incubation, the supernatant was collected by cellulose acetate absorption cartridges (Skatron, Oslo, Norway). Specific ${ }^{51} \mathrm{Cr}$ release was defined as:

(observed release - spontaneous release)

(maximum release - spontaneous release) 
Maximum release, obtained by addition of $0.1 \mathrm{ml}$ of a cetavlon solution to $2.5 \times 10^{3}$ target cells, equaled 90 to $100 \%$ of the total incorporated radioactivity. Spontaneous release measured after incubation of ${ }^{51} \mathrm{Cr}$-labeled kidney cells with medium alone varied from 10 to $30 \%$ of the total incorporated counts.

\section{Monolayers}

Monolayers of leucocytes and PHA stimulated lymphoblasts have been prepared by the method described by Silva (1978), based on the presence of lectin receptors on different cell types, permitting the formation of a confluent and stable monolayer after the addition of target cells to a film of PHA. Briefly, poly-l-lysine, $1 \mathrm{ml}$ $(50 \mu \mathrm{g} / \mathrm{ml})$ was added to a polystyrene tissue culture plate; after I h of incubation at room temperature, $1 \mathrm{ml}$ of $1 \%(\mathrm{v} / \mathrm{v})$ chicken red blood cells was added. The plates were washed in phosphate buffered saline, fixed with a $0.2 \%$ glutaraldehyde, followed by incubation with $0.1 \mathrm{M}$ glycine for $10 \mathrm{~min}$. Before use the plates were incubated for 60 min with $1 \mathrm{ml}$ of PHA 15, 1: 50 diluted in phosphate buffered saline, followed by the addition of $10^{7}$ leucocytes or PHA stimulated lymphoblasts.

To prevent aspecific adsorption of CTLs on PHA which was not covered by the leucocytes, the eventual interstices were covered with syngeneic erythrocytes. After three washings with phosphate buffered saline, the monolayers were ready for use as immunoadsorbant. Effector cells $\left(5 \times 10^{6}\right.$ cells $\left./ \mathrm{ml}\right)$ in $1 \mathrm{ml}$ were incubated on a monolayer for $60 \mathrm{~min}$ at $37 \mathrm{C}$. All monolayers were examined microscopically and only confluent monolayers have been used for adsorbtion experiments. Non-adherent cells were obtained by swirling gently for $10 \mathrm{sec}$ and aspirating the supernatant.

\subsection{Results}

Kidney cells appeared to be useful as targets for cytotoxic effector cells. The specific "Cr release of the kidney cells varied from 50 to $70 \%$ when incubated with effector cells stimulated against the same haplotype as the target, whereas third party kidney target cells were not lysed significantly (Table 1). These findings indicate that cultured canine kidney cells are useful for in vitro studies of cell mediated immunity.

Adsorption studies with different monolayers have been performed, to study whether cytotoxic effector cells recognize identical antigens on kidney cells as on PHA stimulated lymphoblasts. Sensitized effector cells which mediate cytotoxicity have specific receptors which enable these cells to recognize, bind, and destroy target cells which share antigens with the stimulator. These properties allowed the depletion of subsets of effector celis by immunoadsorption on specific target cell monolayers (Berke 1972, Chisholm 1978).

The cytotoxicity of the unadsorbed as well as the non-adherent fraction after adsorption of effector cells, generated in a MLC, was tested. ${ }^{\text {s }} \mathrm{Cr}$-labeled kid ney cells and ${ }^{5 i} \mathrm{Cr}$-labeled PHA stimulated lymphoblasts were used as targets. The results are 
Table I Cell mediated cylotoxicity of target kidney cells by effector cells exposed to antigen determinants of one haplotype mismatched beagles*

\begin{tabular}{|c|c|c|c|c|c|}
\hline \multirow{3}{*}{$\begin{array}{l}\text { Target } \\
\text { colls }\end{array}$} & \multirow{3}{*}{$\begin{array}{l}\text { Simulator } \\
\text { cells }\end{array}$} & \multicolumn{3}{|c|}{ Radioactivity released } & \multirow{3}{*}{$\begin{array}{l}\text { Cytotoxicity } \\
\text { \% }\end{array}$} \\
\hline & & Maximal & Spontaneous & Experimental & \\
\hline & & C.P.M. & C.P.M. & C.P.M. & \\
\hline $1 / 4^{*}$ & $1 / 3 *$ & 2010 & 313 & 349 & 2 \\
\hline $1 / 3$ & $1 / 3$ & 596 & 237 & 488 & 70 \\
\hline $1 / 4$ & $1 / 2 *$ & 1913 & 751 & 715 & 0 \\
\hline $1 / 2$ & $1 / 2$ & 410 & 116 & 263 & 50 \\
\hline
\end{tabular}

$* 1 / 2,1 / 3$ and $1 / 4$ represent different haplotypes.

* Target: effector cell ratio $=1: 20$.

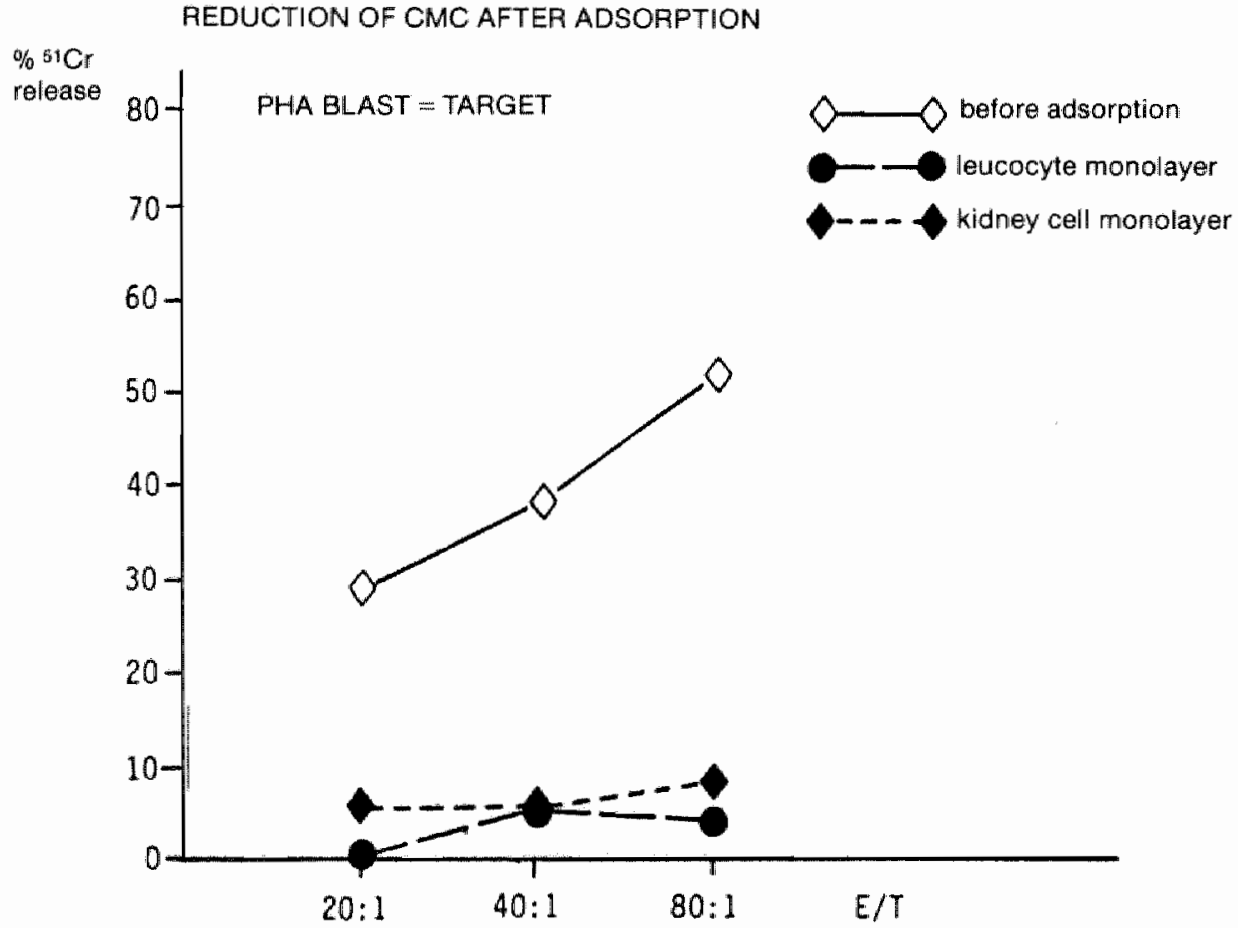

Figure I Reduction of cell mediated cytotoxicity toward PHA lymphoblasts after adsorption of CTL orl tanget specific leucocyte and kidney cell monolayers. (Data given are means of six consecutive experiments.) 
given in Figure 1, both leucocyte and kidney cell monolayers reduced cytotoxicity against ${ }^{51} \mathrm{Cr}$-labeled PHA stimulated lymphoblasts very effectively. The average reduction of cytotoxicity was $86 \pm 17.1 \%$ in six consecutive experiments after one adsorption on either one of these two types of target specific monolayers. Non-specific monolayers reduced cytotoxicity only $13 \pm 14.3 \%$, which differed significantly $(P<0.01)$ from the high, specific reduction obtained.

This indicates that leucocytes and kidney cells share antigems recognized by effector cells. Figure 2 shows the cytotoxicity of identical cell suspensions as used in the former experiments, but now tested against ${ }^{51} \mathrm{Cr}$-labeled kidney cells as the targets. It appeared that specific kidney cell monolayers reduced cytotoxicity against kidney cells allmost completely; however, leucocyte monolayers reduced cytotoxicity toward kidney cells to only $40 \pm 18.7 \%$. The observed cytotoxicity toward kidney cells after adsorption of the effector cell population on a leucocyte monolayer is significantly higher than the observed cytotoxicity after adsorption on a kidney cell monolayer $(\mathrm{P}=0.01)$.

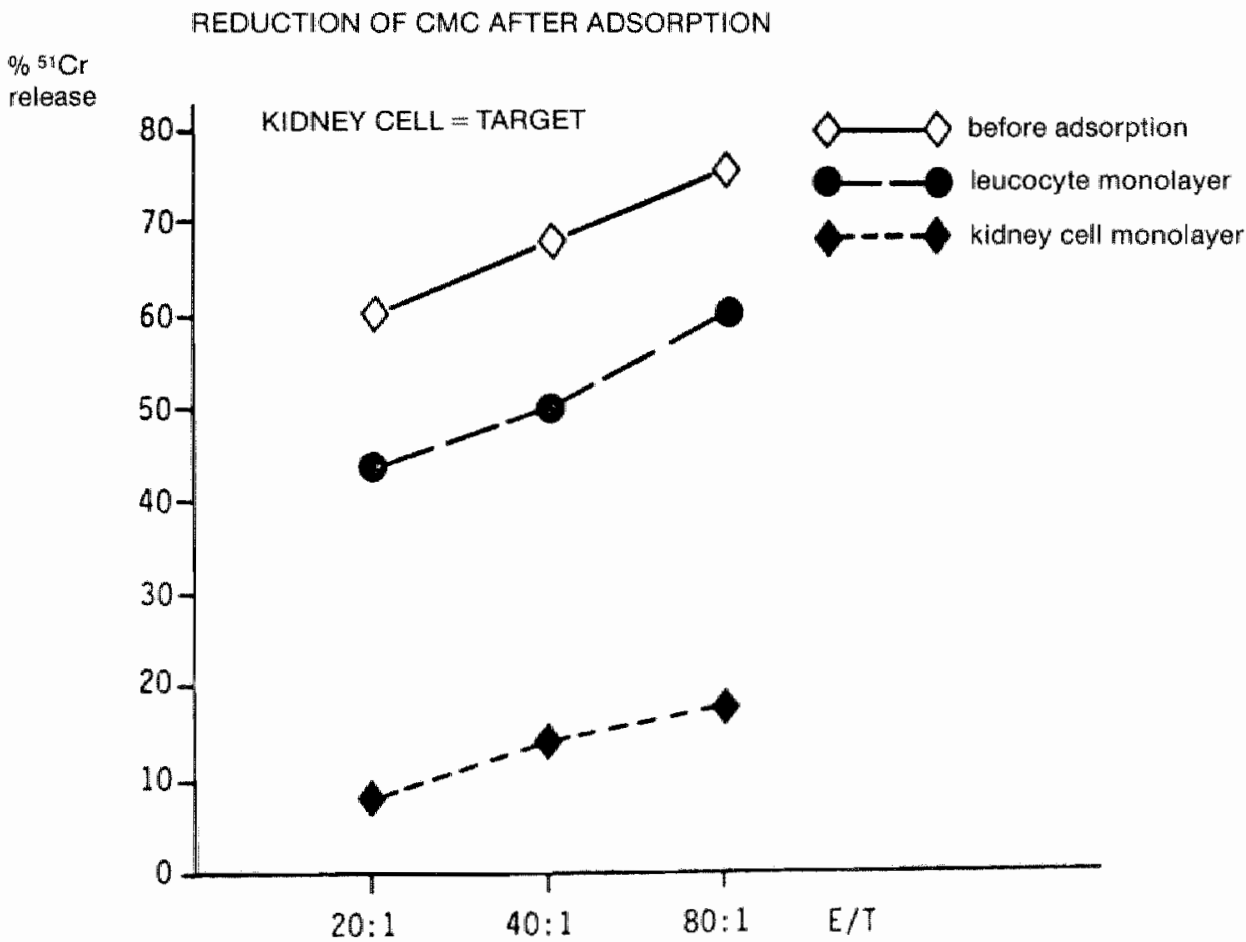

Figure 2 Reduction of cell mediated cytotoxicity toward kidney cell targets after adsorption of CTl. on target specific leucocyte and kidney cell monolayers. (Data given from same experiments as mentioned in fig. 1.) 


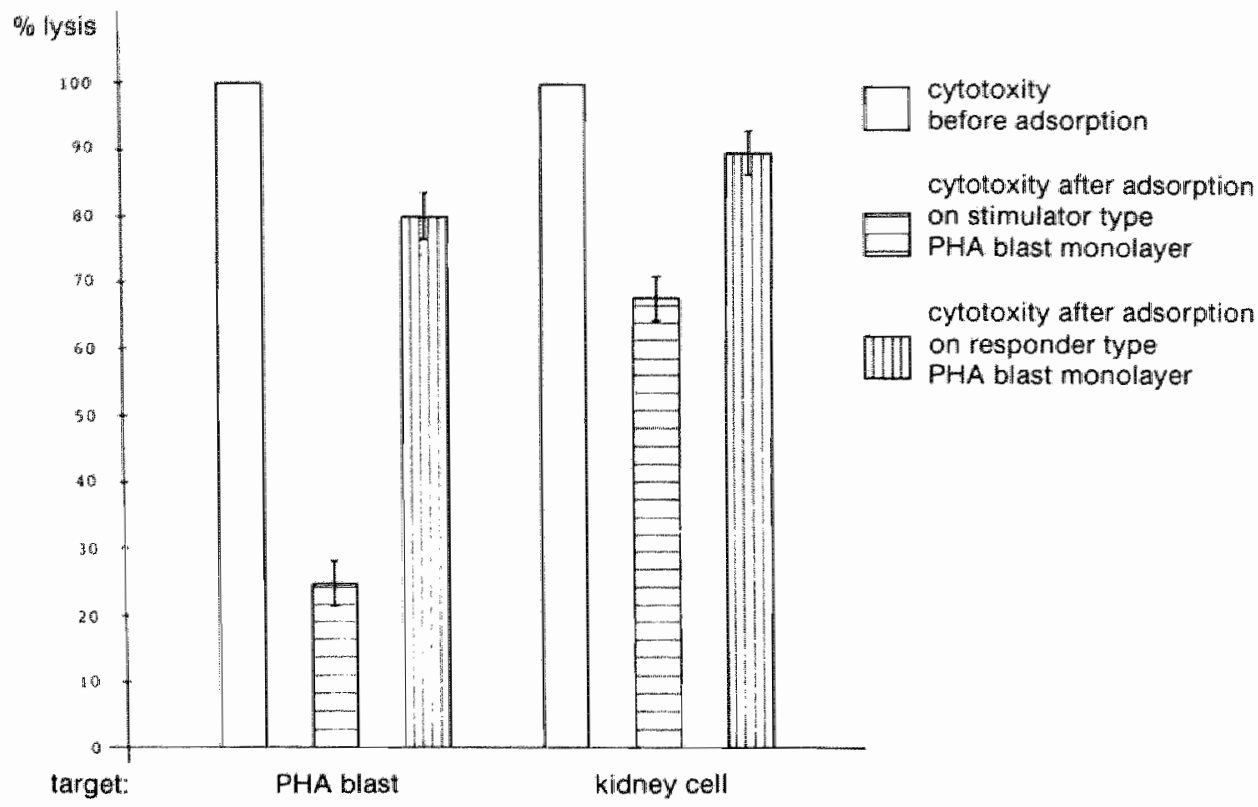

Figure 3 Reduction of cell mediated cytotoxicity toward PHA lymphoblasts and kidney cell targets after adsorption of CTL on target specific and responder specific PHA lymphoblast monolayers. To compare the effect of adsorption of CTL, when tested toward different types of target cells, the cytotoxicity before adsorption was defined as $100 \%$.

Table 2 Cold target inhibition of cell mediated cytotoxicity toward PHA stimulated lymphoblasts and kidney cells by addition of unlabeled PHA lymphoblasts*

\begin{tabular}{|c|c|c|c|c|}
\hline $\begin{array}{l}\text { Priming of } \\
\text { effector cells }\end{array}$ & Target cell & Blocking cell & Cytotoxicity & Reduction \\
\hline$A / B$ & $\begin{array}{l}\text { B PHA blast } \\
\text { B PHA blast } \\
\text { B PHA blast }\end{array}$ & $\begin{array}{l}\text { B PHA blast } \\
\text { C PHA blast }\end{array}$ & $\begin{array}{l}44 \% \\
12 \% \\
44 \%\end{array}$ & $\begin{array}{l}73 \% \\
0 \%\end{array}$ \\
\hline $\mathrm{A} / \mathbf{B}_{\mathrm{K}}$ & $\begin{array}{l}\text { B kidney cell } \\
\text { B kidney cell } \\
\text { B kidney cell }\end{array}$ & $\begin{array}{l}\text { B PHA blast } \\
\text { C PHA blast }\end{array}$ & $\begin{array}{l}46 \% \\
33 \% \\
44 \%\end{array}$ & $25 \%$ \\
\hline
\end{tabular}

* Target effector cell ratio $=1: 20$. 
A second adsorption on a leucocyte monolayer did not further red uce cytotoxicity toward kidney cell targets, which excludes that a lower density of major histocompatibility complex antigens present on leucocyte monolayers was responsible for the difference in adsorption. This indicates the presence of a population of CTLs, cytotoxic for kidney cells, which thave no or only a very low affinity toward leucocytes.

The existence of this population of CTLs specific for kidney cells was confirmed with adsorption studies using monolayers of PHA stimulated lymphoblasts, presenting class $\mathbb{I}$ antigens. It appeared that these monolayers were even less effective than leucocyte monolayers in reducing cytotoxicity toward kidney cells (Figure 3).

Cold target inhibition studies have been performed to confirm the presence of a population of CTLs without affinity toward PHA stimulated lymphoblasts, but cytotoxic for kidney cells. The addition of unlabeled target cells to a culture of sensitized effector cells and labeled target cells will reduce the actual number of effectors directed to the labeled target cells, if the relevant antigens also occur on the unlabeled cells. The effector cells, directed toward other antigens, are not affected.

Unlabeled PHA stimulated lymphoblasts were added to a culture with a fixed amount of effector cells and ${ }^{5 /} \mathrm{Cr}$-labeled PHA stimulated lymphoblasts or ${ }^{5 /} \mathrm{Cr}$ labeled kidney cells. The results of a ty pical experiment are given in Table 2. Addition of target specific unlabeled PHA stimulated blasts to a mixture of CTLs and ${ }^{51} \mathrm{Cr}-$ labeled PHA stimulated target cells reduced cytotoxicity $73 \%$. When the same number of PHA stimulated blasts is added to a culture of CTLs and kidney target cells, the reduction in cytotoxicity was only $25 \%$. In both experiments the addition of third party PHA stimulated blasts did not influence the outcome of the cytotoxicity assays. These results further support the presence of an effector cell population which lacks affinity toward PHA stimulated lymphoblasts but consists of cells cytotoxic for kidney cells.

\subsection{Discussion}

The antigens recognized by the CTL populations which were not cytotoxic for PHA stimulated lymphoblasts and responsible for the cytotoxicity toward the cultured kidney cells have not been revealed yet. The ineffectiveness of adsorption on a PHA stimulated lymphoblast monolayer, presenting class I antigens, in the reduction of cytotoxicity toward kidney cells indicated that the 'kidney-specific' antigens do not belong to class I antigens. The antigens involved in this kidney-specific kill could be either organ-specific antigens or class II antigens.

Beside cellular immune activity, humoral reactivity versus tissue-specific antigens has also been reported. In the rat antibodies against kidney antigens have been observed after allogeneic kidney transplantation (Hart 1980). Clinical studies reported the presence of antibodies for endothellial cells after kidney transplantation (Claas 1980, Paul 1979). These endothelial specific antibodies cross-reacted with monocytes but not with lymphocytes. Furthermore, antiblood-group $\mathbf{B}$ antibodies have been suggested to play an important role in the acute rejection of kidney allografts, by reacting with the endothelial cells of the renal vasculature (Paul 1978). 
The antigens that we have detected on cultured kid ney cells may be an analogue of such a non-HLA system as described by Moreas and Stastny (1977) for the endothelial cells and monocytes. Non-lymphoid cells present among the leucocytes in the stimulator fraction of the MLC may be responsible for the induction of the CTLs directed toward the relevant antigens on kidney cells.

A second possibility could be that class II antigens present on B lymphocytes and monocytes in the stimulator fraction of the MLC were responsible for the induction of the subset of CTIs directed to class 11 antigens on canine kidney cells. Cell mediated cytotoxicity toward class II antigens has been reported by several investigators (Feighery 1979, Johnson 1980). The presence of class II antigens on canine kidney cells is expected since we observed lymphocyte stimulation by allogeneic cultured kidney cells (Vegt 1982).

Stimulating properties of non-lymphoid cells, demonstrating class II antigens, have been reported for several species. In the rat mixed skin leucocyte reactions have been reported by Tanaka (1979). Kidney cells could also stimulate leucocytes in the rat (Mashimo 1976). Furthermore, lymphocyte stimulation in vitro by dissociated heart cells and liver cells has been reported (Sakai 1977, Sakai 1978). This indicates the presence of class 11 antigens on several tissues in the rat. Also, in the pig the presence of class $I I$ antigens has been reported on cultured and fresh kidney cells as on B lymphocytes and macrophages (Davies 1976). Williams (1980) demonstrated class 11 antigens on human kidney cells in a substantially greater amount than in the rat kidney.

Recently, class II antigens bearing T lymphocytes have been reported in man. Ko (1979) found class II antigens on a small population of 2 to $6 \%$ of purified T lymphocytes. Evans (1978) observed class II antigens on a larger fraction of $\mathrm{T}$ lymphocytes stimulated in vitro by specific antigens, as well as by mitogens such as concanavalin A and PHA. The presence of class II antigens on a limited number of PHA stimulated lymphoblasts may account for the reduction of cytotoxicity toward kidney cells obtained after adsorption on a monolayer of PHA stimulated lymphoblasts.

The nature of the target antigens detected on cultured kidney epithelial cells remains to be further investigated. These antigens could be of great value for matching donor and recipient combinations in order to obtain a better selection for kidney transplantation. Our cell mediated cytotoxicity model against kid ney cells might also present a valuable tool for monitoring the cellular immunity of a recipient toward donor specific kidney antigens.

\subsection{Summary}

Cellular cytotoxicity toward kidney cell targets has been studied in a model using in vitro cultured canine kidney cells obtained after perfusion trypsinization of kidneys from one-haplotype mismatched beagles.

To study whether cytotoxic effector cells recognize identical antigens on kidney cells as on phytohaemagglutinin (PH A) stimulated lymphoblasts, adsorption studies 
with different monolayers have been performed. Both leucocyte and kidney cell monolayers reduced cytotoxicity against ${ }^{5} \mathrm{Cr}$-labeled PHA stimulated lymphoblasts very effectively. The average reduction of cytotoxicity was $86 \%$ in six consecutive experiments after one adsorption on either one of these two types of target specific monolayers. Non-specific monolayers reduced cytotoxicity only for $13 \%$. Specific kidney cell monolayers reduced cytotoxicity against kid ney cells almost completely, however leucocyte monolayers reduced cyt toxicity toward kidney cells for anlly $40 \%$. These results and cold target inhibition data strongly suggest that kidney cells present antigens to which a selective population of cytotoxic T lymphocytes (CTLs) is directed. These CTLs are not cytotoxic for PHA stimulated lymphoblasts. It is discussed whether the relevant antigens on the kidney cells are organ specific antigens comparable to the endothelial monocyte antigen system as described by Moreas and Stastny or that class 11 antigens are involved in cytotoxicity toward kidney cel.Js.

\section{Acknowledgements}

We would like to thank Dr. A. Munro for helpful discussions of the manuscript and Marijke van den Berg for her excellent secretarial assistance. Dr. J. Bouma kindly supported us with highly purified antifactor VIII antiserum.

This chapter has been published in Transplantation.

P.A. Vegt, W.A. Buurman, C.J. van der Linden, A.J.J.M. Daemen, J.M. Greep, and J. Jeekel. Cell mediated cytotoxicity toward canine kidney epithelial cells. Transplantation 1982; 33: 465 .

\subsection{References}

Bach FH, Segall M, Zier KS, Sondel PM, Alter BJ, Bach ML. Cell mediated immunity: separation of cells involwed in recognitive and destructive phases. Science 1973; 180:403.

Berke $G$, Levey $R$. Cellular immunoabsorbents in transplantation inmunity. J Exp Med 1972; 135:972.

Chisholm $\mathrm{PM}$, Ford WL. Selection of antigen-specific cells by adherence to allogeneic cell monolayers: cytolytic activity, graft-vs -host activity and numbers of adherent and nonadherent cells. Eur \& Immunol 1978; $8: 438$.

Claas FHJ, Paul LC, van Es LA, van Rood J I. Antibodies against donor antigens on endothelial colls and monocytes in eluates of rejected kidney allografts. Tissue Antigens 1980; $15: 19$.

Davies HS, Taylor JE, Daniel MR, Wakerly C. Differences bet ween pig tissues in the expression of major transplantation antigens: possible relevance for organ allografts. $J$ Exp Med 1976; 143:987.

Evans RL, Faldetta TJ, Humphreys RE, Pratt DM, Yutis EJ, Schlossman SF. Peripheral human $T$ cells sensitized in mixed leukocyte culture synthesize and express la-like antigens. J Exp Med 1978; 148: 1440.

Feighery $C$, Stastny $P$. HLA-D region-associated determinants serve as targets for human cell mediated lysis. I Exp Med 1979; 149: 485.

Gilbert SG. Migeon BR. d-Vatine as a selective agent for normal human and rodent epithelial cells in culture. Cell 1975; 5 : 11 . 
Hart DNI Fabre IW. Kidney-specific alloantigen system in the rat. Characterisation and role in transplanLation. J Exp Med 1980; 151:651.

Jaffe EA, Machman RL, Becker $C \mathrm{C}$, Minick $\mathrm{RC}$. Culure of human endothelial cells derived from umbiheal veins. Identification by morphologite and immunologic criteria. J Clin Invest 1973;52:2745.

Johnson HE. Hunan B-blas: specife target determinatants in CML: a methodological study. Tissue Antigens 1980; 15: 189.

Ko HS, Fu SM, Winchester RJ, Yu DTY, Kunkel HG. la determinants on stimulated human T Iymphocytes: occurence on mitogen and antigen activated Toells. J Exp Med 1979; 150: 246.

Lightbod $y$ In nernoco D, Miggiano VC, Ceppellini $\mathrm{R}$. Cell mediated lympholysis in man after sensitization of effector lymphocytes through mixed leucocyte cultures. I Bacterial Virol Immunol 1971; 64: 234 .

Mashimo S, Sakai A, Ochia $T$, Kountz SL. The mixed kidney cell-lymphocyte reaction in rats. Tissue Antigens. 1976:7:291.

Moreas JR, Stastny $\mathrm{P}$. A new antigen system expressed in human endothelial cells. I Clin Invest 1977; 60: 449.

Paul LC, van Es LA, Brutèl de la Rivière $G$, Eernisse $G$, De Graeff J. Blood group B antigens on renal epithelium as the target for rejection in an $\mathrm{ABO}$-incompatible recipient. Iransplantation 1978; $26: 268$.

Paul LC, van Es LA, van Rood Jy, van Leewwen A, Brutèl de la Rivière G, De Graeff J. Antibodies directed against antigens on the endothelium of peritubular capillaries in patients with rejecting renal allografts. Transplantation $1979 ; 27$ : 175 .

Sakai A, Kashiwabara H, Taha M, Kountx $S$. The role of organ-specific antigens in the AgB-compatible graft rejection. Transplant Proc 1977; 9:629.

Sakai A. Taraka S, Kountz SL. Liverand immune responses. IV. Characteristics of the liver cell-lymphocyte interaction. Tramsplantation $1978 ; 25 n$, 110.

Shaw $S$, Johnson $A H$, Shearer GM. Evidence for a new segregant series of $B$ cell antigens that are encoded in the HLA-D region and that stimulate secondary allogeneic proliferative and cylotoxic responses. $J$ Exp Med 1980; 152: 565 .

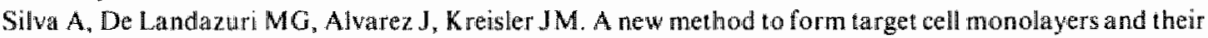
use for the immunoadsorption of cytotoxic effector cells. J Immunol Methods 1978; 23: 303.

Tanaka S. Sakai A. Stimulation of allogeneic lymphocytes by skin epidermal cells in the rat. Transplantation 1979: 27: 194.

Williams KA, Hart DNJ. Fabre JW, Morris PJ. Distribution and quantification of HLA-ABC and DR (la) antigems on human kidney and other tissues, Transplantion 1980;29: 274. 


\section{Chapter 5}

\section{Lymphocyte stimulation by canine kidney cells}

\subsection{Introduction}

Mixed kidney cell leucocyte cultures provide an in vitro model for the study of allograft rejection, since kidney cells carry the antigens against which a rejection reaction is directed. It has been reported that lymphocyte stimulation occurs in mixed cultures with non-lymphoid stimulator cells. Lymphocyte stimulation with kidney cells has been reported for the rat (Main 1975, Mashimo 1976), pig (Pawelec 1979), and $d o g$ (Lifton 1977).

The nature of the antigens on non-lymphoid cells which trigger lymphocyte proliferation in such cultures has not been revealed yet. Hirschberg and Thorsby (1975) showed with a ${ }^{3} \mathrm{H}$-thymidine suicidal technique that lymphocytes proliferating in response to allogeneic lymphocytes of a particular donor were eliminated, whereas lymphocytes capable of reacting toward epidermal cells of the same donor were not eliminated. They concluded that antigens other than MHC antigens present on epidermal cells are stimula tory to allogeneic lymphocytes. Since anti-HLA antibodies which reacted with the relevant donor inhibited the lymphocyte response to epidermal cells, it had been concluded that the specific antigens of epidermal cells were closely associated with MHC antigens. Further evidence for tissue specific antigens stimulatory to lymphocytes has been reported by Pawelec et al. ( 1979$)$. They observed that lymphocyte stimulation occurred between MHC-identical pigs, if kid ney cells or liver cells were used as stimulator cells.

Species differences for lymphocyte stimulation with non-lymphoid cells have been reported for endothelial cells. Porcine endothelial cells have been reported to be not stimula tory to lymphocytes whereas human and canine endothelial cells are stimulatory to lymphocytes (Pawelec 1979, Hirschberg 1975, Vetto 1972). This fact might be very relevant for renal allograft rejection studies, since endothelial cells present the first foreign contact in the graft to the immunocompetent cells of the host.

In this report lymphocyte stimulation by cultured canine kidney epithelial cells has been studied. Attention is paid to the epithelial origin of the cultured cells and the differences between lymphocyte stimulation induced by kidney epithelial cells and by leucocytes. 


\subsection{Materials and Methods}

\section{Animals}

Closely bred beagles and Flemish sheep dogs of the colony of the University of Limburg were used in all experiments.

\section{Leucocyte cell suspensions}

Peripheral blood leucocytes have been isolated with Lymphoprep (Nyegaard, Oslo, Norway) from heparinized blood samples taken from the jugular vein of the dogs. The leucocyte suspensions obtained, consisted of 30-70\% lymphocytes (Buurman 1982).

\section{Kidney cells}

Under sterile conditions unilateral nephrectomy was performed. The kidney was flushed with Euro-Collins and transported into a laminar flowhood. Perfusion trypsinization was carried out with a trypsin solution $(0.25 \%$ trypsin in a citrate buffer at $37 \mathrm{C}$ ). The kidney capsula and all adjuvant connective tissue and fat tissue were removed mechanically during the $40 \mathrm{~min}$ trypsinization. The trypsinized cortex and medulla were minced with scalpels and dissociated by careful sonication. The cell suspension obtained after this procedure was sieved $(60 \mu \mathrm{m}$ diameter gauze) and washed with minimal essential medium (MEM) plus 10\% heat inactivated newborn calf serum. The cells were cultured at $37 \mathrm{C}$ in closed plastic tissue culture flasks, $175 \mathrm{~cm}^{2}$, in MEM plus Hanks' salt solution, $10 \%$ newborn calf serum, $5 \%$ lactalbu$\mathrm{min}, 2 \mathrm{mM}$ glutamine, 100 IU of penicillin per $\mathrm{ml}$, and $100 \mu \mathrm{g}$ of streptomycin per $\mathrm{ml}$ were added. For selection of epithelial cells, the cells were cultured from the first passage on in MEM D-valine plus 5\% newborn calf serum plus glutamine plus antibiotics. Kidney cells of three and four passages have been used for MKLCs.

\section{Anti-F VIII immunofluorescense}

Intracellular immunofluorescence was performed on cells cultured on microscope slides with Lab-Tab 4808 (Miles, Naperville, Illinois) tissue culture chambers. Cells were fixed in methanol plus $5 \%$ acetic acid at $-20 \mathrm{C}$, rinsed with phosphate-buffered saline, and incubated for 45 min at $37 \mathrm{C}$ with rabbit anti-F VIII. The highly purified anti-F VIII, obtained by absorption of rabbit anti-canine $\mathbb{F}$ VIII with serum proteins of dogs with Von Willebrands disease, was kindly provided by Dr. J. Bouma, Department of Haematology, State University Utrecht. The slides were washed extensively for 15 min in phosphate-buffered saline and subsequently incubated with a goat anti-rabbit $\mathrm{IgG}$ fluorescein isothiocyanate conjugate for 45 min at $37 \mathrm{C}$. The 
slides were washed and mounted with glycerol-phosphate-buffered saline, displacement of the cover slip was prevented by collorless nail polish painted around the edges of the cover slip. The preparations were examinated immediately or stored at $-20 \mathrm{C}$ until examination.

\section{MLC and MKLCs}

Stimulator cells in the mixed cultures were either leucocytes or freshly detached (with $0.2 \%$ EDTA) cultured kid ney cells. All stimulator cells were irradiated with $2500 \mathrm{rad}$, $250 \mathrm{kV}, \mathrm{X}$-rays.

Mixed cell cultures were performed in round bottom standard microtiter plates. The medium used in these experiments was RPMI $1640+25 \mathrm{mM}$ HEPES $+2 \mathrm{mM}$ glutamine $+10 \%$ heat inactivated pooled dog serum $+100 \mathrm{IU}$ of penicillin per $\mathrm{ml}$ $+100 \mu \mathrm{g}$ of streptomycin per $\mathrm{ml}$. In all experiments $10^{5}$ responder leucocytes have been used and all samples were tested in six-fold. The cells were incubated for a given number of days at $38 \mathrm{C}$ in a humidified atmosphere of $5 \% \mathrm{CO}_{2}$ in air. Lymphocyte proliferation was measured after an incubation for $4 \mathrm{~h}$ with $1 \mu \mathrm{Ci}$ of ${ }^{3} \mathrm{HTdR}$. Cultures were harvested with a microplate harvester and the incorporated radioisotope was measured in a liquid scintillation spectrofotometer.

\subsection{Results}

\section{Identification of cultured kidney epithelial cells}

The in vitro cultured kidney cells were epithelial in morphological appearance (Figure 1). Further suggestive evidence for the epit helial character of the cultured cells was obtained by immunofluorescence with anti-F VIII. Endothelial cells have been reported to produce $F$ VIII which can be detected with intracellular anti-F VIII immunofluorescence (Jaffe 1973). Fluorescence with anti-canine F VIII revealed that cultured canine kidney cells did not show any significant fluorescence (data not shown), whereas cultured canine venous end othelial cells obtained by collagenase digestion of the vena cava showed strong specific intracellular fluorescence (Figure 2).

Growth of fibroblasts was inhibited by use of D-valine MEM, a selective medium which inhibits the growth of fibroblasts, since these cells a re not capable of converting D-valine into the essential amino acid L-valine. Kidney epithelial cells have been reported to carry the relevant enzymes and to grow in D-valine MEM (Gilbert 1975). Cultures which still showed any morphological signs of possible fibroblastoid cell growth were omitted. The presence of lymphocytes, mononuclear phagocytes and dendritic cells was excluded by microscopy. 


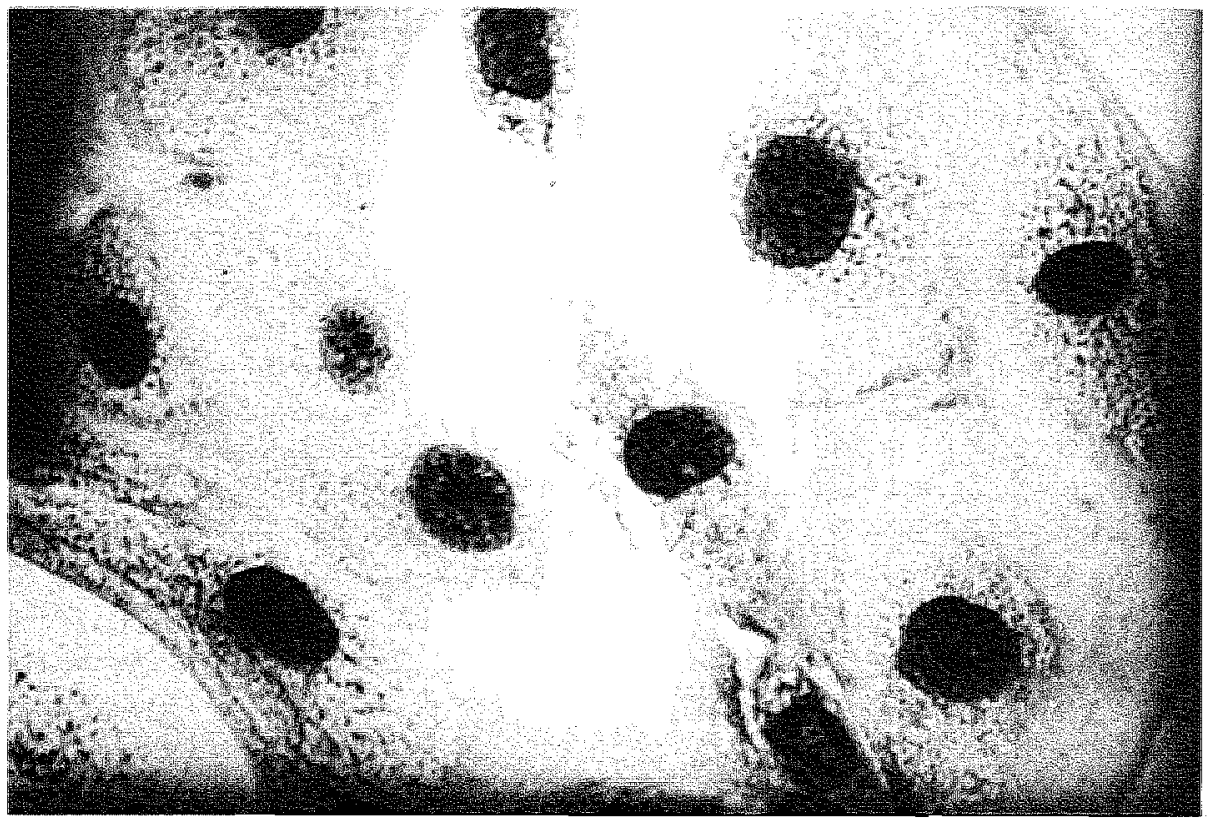

Figure I In vitro cultured canine kidney epithelial cells stained with haematoxilin-eosin.

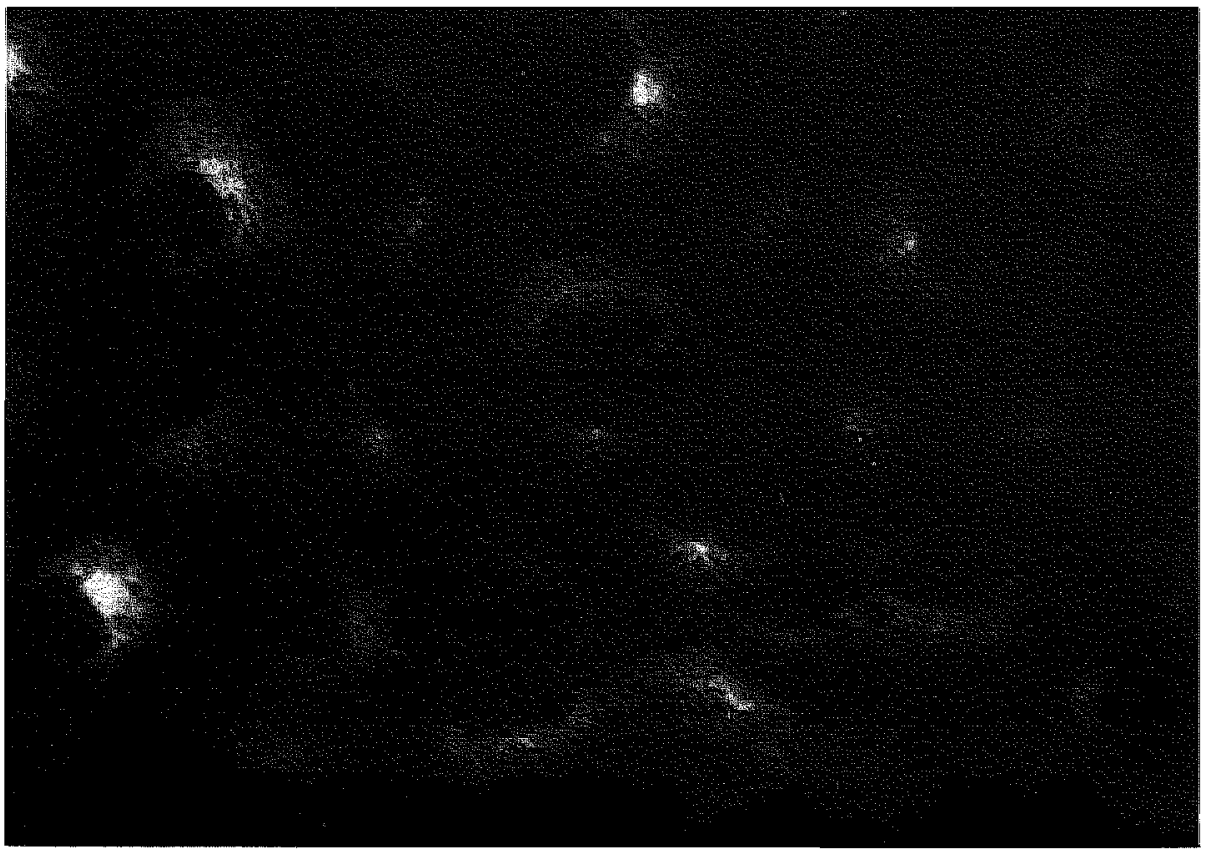

Figure 2 Intra cellular immunofuorescence of in vitro cultured cells. Camine venous endothelial cells show strong positive intracellular immurofluorescence with anti-canine $F$ VIIl. 


\section{Lymphocyte stimulation by cultured kidney epithelial cells}

Unilateral nephrectomy followed by perfusion trypsinization and in vitro culture of the kidney epithelial cells permitted us to compare MKLCs and MLCs in which the stimulator cells originated from the same dog.

The kinetics, S : R cell ratio, and time-response relation of the MKLC and MLC have been studied. A constant number $\left(10^{5}\right)$ of leucocytes was stimulated wit harrying numbers $\left(\llbracket 0^{3}\right.$ to $\left.1.5 \times 10^{5}\right)$ of allogeneic irradiated kidney cells or leucocytes (Figure 3). The time response relation of both the MKLC and the MLC were identical: maximal lymphocyte proliferation was obtained on day 6 of culture, followed by a decreased proliferation at longer culture times. The maximal proliferation for the MKLC was about $\mathbb{1 3} \%$ of the maximal proliferation observed for the MLC in this experiment.

The optimal $S: R$ cell ratios appeared to be different. Optimal stimulation in a MKLC ( $10^{5}$ responder leucocytes) was observed with $5 \times 10^{3}$ irradiated kidney stimulator cells $(S: R$ ratio $=1: 20)$, whereas optimal stimulation of $10^{5}$ responder cells in a MLC was obtained with $1.5 \times 10^{5}$ irradiated stimulators $(\mathrm{S}: \mathrm{R}$ ratio $=$ $1.5: 1)$. The stimulation indices of this experiment are given in Table I. Significant stimulation was observed for the MKLC at $S: R$ ratios of $1: 10,1: 20$, and $1: 100$. This is in contrast with the MLC, which showed no significant stimulation at $S: R$ ratios $<1: 20$.

$S: F=1 \frac{\pi}{n}: H$

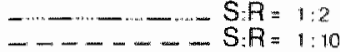
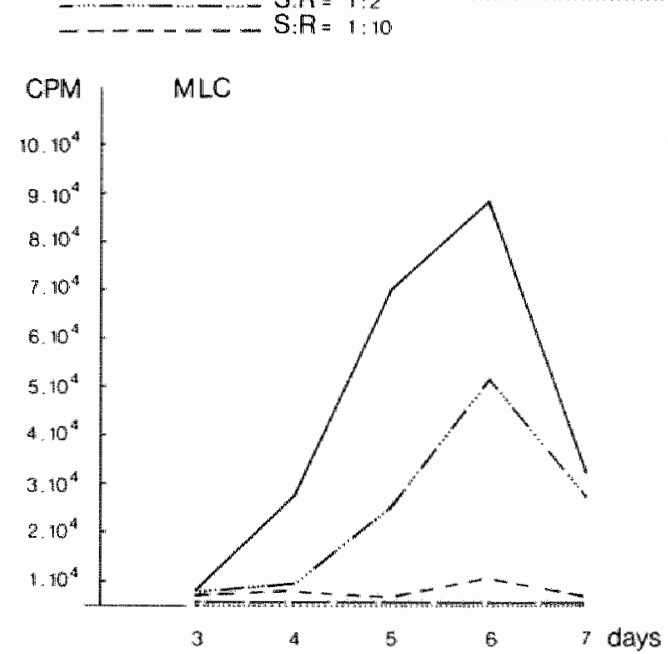

$S: R=1: 20$

S: $:$ : $=100$

Figure 3 Mixed lencocyte and mixed kidney cell leucocyte cultures. Mixed cultures have been performed at different stimulator: responder cels ratios, lymphocyte proliferation has been determined longit udinally as ${ }^{3} H$ Td R uptake expressed in c.p.m. A constant number (109) of leucocytes was stimulated with varying mumbers of irradiated kidney cells or leucocytes of a dog which differed for one haplotype with the responder. 
Table / Canine kidney cellymphocyte and mixed lymphocyte culture

\begin{tabular}{lllllllllll}
\hline & A & B & A & B & A & B & A & B & A & B \\
\hline Stim./resp. ratio & $11 / 2: 1$ & & $1: 2$ & & $1: 10$ & $1: 20$ & $1: 100$ \\
\hline Day 3 & 1.3 & 9.1 & 5.0 & 5.6 & 2.7 & 1.9 & 4.22 .0 & 2.0 & - \\
Day 4 & 1.4 & 48.0 & 3.5 & 18.9 & 4.2 & 5.5 & 8.3 & 1.9 & 2.3 & - \\
Day5 & 1.9 & 122.6 & 1.8 & 41.6 & 7.1 & 4.3 & 11.82 .1 & 4.6 & $\ldots$ \\
Day 6 & 11.0 & 155.2 & 2.2 & 91.0 & 10.9 & 18.4 & 20.4 & 0.6 & 6.8 & - \\
Day7 & 1.6 & 55.9 & 1.1 & 49.0 & 8.6 & 5.0 & 16.5 & 0.9 & 5.3 & - \\
\hline
\end{tabular}

$\mathrm{A}=$ kidrueymllymphocyte culture; $\mathrm{B}=$ lymphocyte-lymphocyte culture; responder lymphocytes : 10 cells/ well.

These data show that cultured kid ney epithelial cells have good stimulatory capacity, as well as an inhibitory effect, which became apparent at a $S: R$ ratio $>1: 20$. The inhibitory effect was studied in MLC experiments in which irradiated responder leucocytes or responder cultured kidney cells were added in graded numbers to a mixed leucocyte culture. Respectively $10^{3}, 5 \times 10^{3}, 10^{4}$, and $10^{5}$ irradiated responder leucocytes or kidney cells were added to MLCs of $1.5 \times 10^{5}$ stimulator and $10^{5}$ responder cells. It appeared that the addition of irradiated responder type kidney cells inhibited the MLC response from dosages of 1 : 100 of the responder cells and higher, whereas the addition of irradiated responder leucocytes did not show any inhibitory effect on the response (Figure 4).

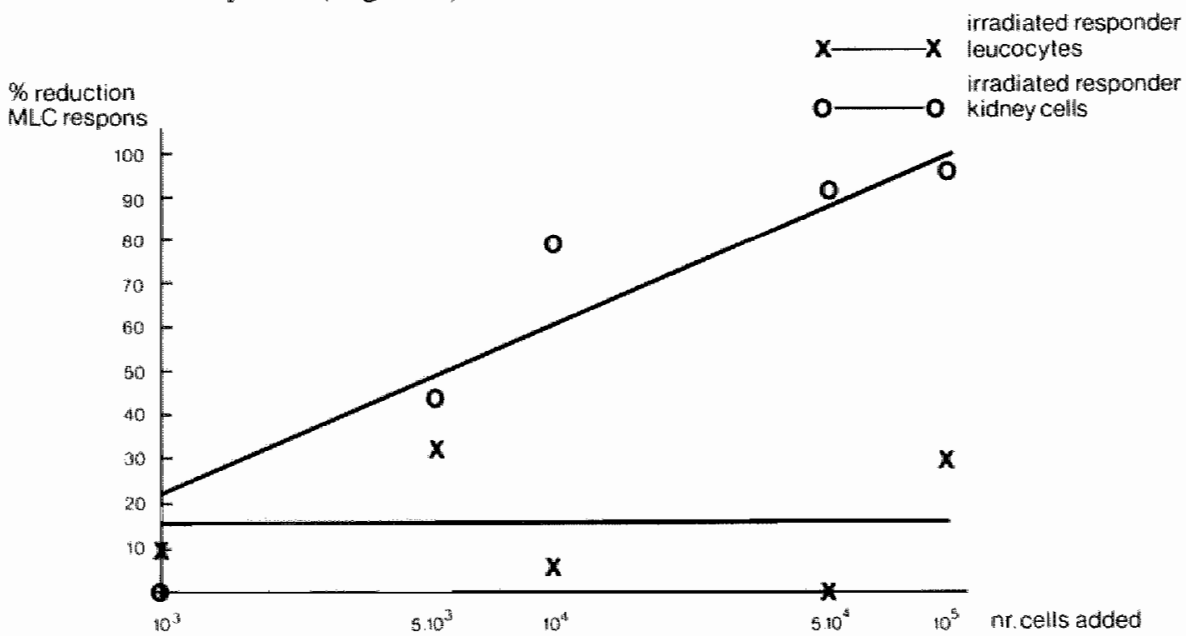

Figure 4 Influence of the addition of irradiated responder canine cultured kidney epithelial oells and leucocytes on lymphocyte proliferation in MLC. Graded numbers of irradiated (2500 rad) kidney cells or leucocytes were added $1010^{5}$ responder and $1.5 \times 10^{5}$ irradiated stimulator leucocytes. Lymphocyte proliferation has been determined as 'HTdR uptake on day 6 of culture. 
Experiments have been performed in order to study whether lymphocyte stimulation in the MKLC in the dog is dependent on differences between stimulator and responder cells for MHC antigens or whether lymphocyte stimulation is independent of $\mathrm{MHC}$ antigens. MKLC and MLC experiments have been performed between a number of $\mathrm{MHC}$ identical and non-identical animals. Identity for $\mathrm{MHC}$ antigens resulted in an absence of a response for the MKLC and MLC (Table 2), In the presence of a MHC difference, which resulted in a MLC response, a significant response in the MKLC has been observed.

Table 2 Genetic control of MKLCand MLC studied with M HC identical and one haplotype mismatched beagles'.

\begin{tabular}{|c|c|c|c|c|c|c|c|c|c|c|}
\hline & Resp & der cell: & & & & & & & & \\
\hline $\begin{array}{l}\mathrm{S} \\
\mathrm{t}\end{array}$ & $\operatorname{dog}$ & 111 & 119 & 122 & 126 & 128 & 132 & 143 & $136^{2}$ & 1273 \\
\hline$\stackrel{\mathrm{i}}{\mathrm{m}}$ & 111 & $-1{ }^{3}$ & -1 & $1-$ & $-1-$ & $-1-$ & $-1-$ & $-1-$ & $+1+$ & $+1+$ \\
\hline $\begin{array}{l}\mathrm{u} \\
\mathrm{l}\end{array}$ & 126 & $-1-$ & $-1-$ & $-1-$ & $-1-$ & $-1-$ & $-1-$ & $1-$ & $+1+$ & $+1+$ \\
\hline a & 131 & -1 & $-1-$ & $-1 \ldots$ & -1 & $-1-$ & $-1 \ldots$ & $-1-$ & $+1+$ & $+1+$ \\
\hline $\begin{array}{l}t \\
0\end{array}$ & 135 & $-1-$ & $-1-$ & $-1-$ & $-1-$ & $-1-$ & $-1-$ & $-1-$ & $+1+$ & $+1+$ \\
\hline $\begin{array}{l}r \\
s\end{array}$ & 136 & $+1+x$ & $+1+$ & $+1+$ & $+1+$ & $+1+$ & $+1+$ & $+1+$ & $-1-$ & $-1-$ \\
\hline
\end{tabular}

Dogs no. $111,119,122,126,128,132,143$ carry a $1 / 3$ haplotype.

2 Dogs no. 136, 127 carry a 1/2 haplotype.

3 -/ negative MLC response: +/ positive MLC response; / - negative MKLC response; / + positive MKLC response.

MLC response was considered positive if the average stimulation index of 3 separate experiments was $\geqslant 3,0$ and megative if the stimulation index was $<3,0$.

\subsection{Discussion}

The present experiments were performed to study whether canine kidney epithelial cells exhibit antigens stimulatory to allogeneic lymphocytes. One of the main concerns was to rule out the contamination of the cultured kidney epithelial cells with endothelial cells, fibroblasts, "passenger" leucocytes, and dendritic cells. The fact that different antigeneic systems have been discovered for polymorphonuclear cells (Thompson 1980), mononuclear phagocytes and endothelial cells (Moraes 1977) stresses the importance of characterization of the cells used for stimulation experiments. The ability of D-valine medium to inhibit growth of fibroblasts in cultures derived from the trypsinized kidney has enabled the selective proliferation of epithelial cells in the absence of fibroblasts. Cultured kidney epithelial cells grown in D-valine medium have been suggested to be of tubular origin (Gilbert 1977). 
The cultured cells have been detached from the plastic culture flasks with EDTA in order to exclude the possibility of altered antigenic properties of the cells, since Poste (1971) has reported that proteolytic enzymes adsorbed to the cell surface, prevent the formation of glycoprotein cell coat material for as long as $24 \mathrm{~h}$.

A crucial question concerns the true immunologic nature of the response of lymphocytes toward non-lymphoid stimulator cells. In the presented situation, the suggestion that lymphocyte stimulation observed in the MKLC is a true immunological response of lymphocytes toward the kidney cell stimulators, which are devoid of cells with known Class II antigens as endothelial cells and dendritic cells is likely. Contamination with leucocytes, lymphocytes, polymorphonuclear cells, and mononuclear phagocytes has not been observed microscopically. The low $S: R$ ratios which still give significant stimulation are indicative of the fact that other cells are stimulators. Recently, it was suggested that contamination with dendritic cells might be responsible for the stimulation in MKLCs (Hart 1981). Since it is reported that dendritic cells do not proliferate in vitro and survive only for a few days under special culture conditions (Steinman 1979), we used as stimulators only kid ney cells of three and four passages, which are 15 days or more in culture. Furthermore, the monolayers were microscopically free of dendritic cells.

The time-response relationship of the lymphoproliferative response of the MKLC is identical to that of the MLC. Furthermore, autologous lymphocytes as well as allogeneic lymphocytes from MHC identical animals have been observed not to be stimulated by kidney cells.

The low optimal $\mathrm{S}: \mathrm{R}$ ratio observed for lymphocyte stimulation by non-lymphoid cells presents an interesting difference with lymphocyte stimulation by lymphoid cells. It strongly favors the point that the cultured kidney epithelial cells are true stimulator cells since stimulation can not be explained by minor contamination with leucocytes, which do not stimulate at such low S : $\mathrm{R}$ ratios. Our data have confirmed that of several authors, but are at variance with the data of others. Both for rat and porcine kidney cells, optimal stimulation has been described at $S: \mathbb{R}$ ratios of $1: 16$ to $1: 20$ (Mashimo 1976, Pawelec 1979). For stimulation with rat لliver cells, optimal $S: R$ ratios of 1: 50 and 1: 100 have been observed (Sakai 1978). Lifton (1977) observed lymphocyte stimulation by allogeneic canine kidney cels at a $S: R$ ratio of $1: 2.4$, which approaches the ratio of $1: 2$ at which we obserwed no stimulation.

Experiments proved that irradiated cultured kidney cells inhibit lymphocyte proliferation in response to an allogeneic stimulus. These data suggest that lymphocyte stimulation in the $\mathrm{MKLC}$ is a result of stimulation by allogeneic antigens in combination with an inhibition by the cells carrying these antigens, which explains the relatively low $S: R$ ratio for optimal stimulation and the reduced maximal proliferation compared with the MLC. Also, endothelial cells (Hirschberg 1975) and fibroblasts (Schellekens 1970) have been reported to inhibit lymphocyte stimulation. Non-specific cell death attributable to overpopulation has been suggested as an explanation (Sakai 1978). The consumption of 112 could also be responsible for the observed inhibition. However, the underlying mechanism for this phenomenon is still unknown. Moreover, its relevance for the in vivo situation is unclear. The fact that 
kidney epithelial cells can induce proliferation at very low $S$ : $R$ ratios indicates that these cells have very strong stimulator capacities compared with those of leucocytes.

As to the antigens on the cultured kidney cells, which are stimulatory to lymphocytes, the results presented show no evidence for tissue specific non-MHC antigens. These data are at variance with those of Pawelec (1979), who observed lymphocyte stimulation by kidney cells and liver cells of MHC identical animals. Furthermore, rat liver cells, human endothelial cells, and human skin cells have been reported to carry tissue specific antigens stimulatory to lymphocytes (Hirschberg 1975a, Hirschberg 1975b, Sakai 1978). It is not clear in our system nor in that of the latter authors, whether a disparity for Class II antigens is a prerequisite for lymphocyte stimulation by non-lymphoid cells. Lymphocyte stimulation by kidney epithelial cells as observed in our experiments might be induced by tissue specific antigens recognized in combination with a MHC difference. Suggestive evidence for this possibility has been reported (Hirschberg 1975).

We observed that cytotoxic $\mathrm{T}$ lymphocytes (CTLs), generated in a canine MLC, recognize target antigens on kidney cells of the stimulator which are not present on phytohaemagglutinin blasts of the stimulator (Vegt 1982). Whether these antigens play a role in the MKLC response remains to be solved since besides antigens which are stimulatory to lymphocytes and induce lymphocyte proliferation, target antigens for CTLs exist which do not induce lymphocyte proliferation.

Recently, generation of CTLs in MKLC has been observed (Buurman 1981). It will be important to study whether CTLs specific for tissue specific target antigens are generated in the mixed kidney lymphocyte culture as has been observed in the mouse for non-MHC alloantigens on mouse epidermal cells (Steinmuller 1981).

\subsection{Summary}

Lymphocyte stimulation in mixed kidney cell leucocyte cultures (MKLC) has been investigated in a canine model. Canine kidney cells were obtained by perfusion trypsinization. Cultured kidney cells, which appeared to be of epithelial origin by several criteria, have been used as stimulator cells. Maximal stimulation was obtained in the MKLC and mixed leucocyte culture (MLC) at stimulator to responder ( $: \mathbb{R}$ ) cell ratios of $1: 20$ and $1.5: 1$, respectively. Lymphocyte proliferation has been observed in cultures with kidney cells in $S: R$ cell ratios lower than $1: 20$. Stimulation has not been observed in MLCs at these low ratios. The addition of graded numbers of kidney cells of the responder to a one way MLC inhibited the response gradually. The fact that kidney cells have both strong stimulator capacities and inhibitor capacities could explain the lower optimal $S: R$ ratio.

Lymphocyte stimulation has not been obtained in mixed kid ney leucocyte cultures between major histocompatibility complex (MHC)-identical closely bred animals. The nature of the antigens present on canine kidney epithelial cells stimulatory to allogeneic lymphocytes is discussed. 
G.M.A.A. Jeunhomme provided excellent technical assistance. We thank M. van den Berg for her helpful secretarial assistance.

This chapter has been published in Transplantation.

P.A. Vegt, C.J. van der Linden, A.J.J.M. Daemen, J. Jeekel and W.A. Buurman. Lymphocyte stimulation by canine kidney cells. Transplantation $1982 ; 34: 134$.

\subsection{References}

Buurman WA, Vegt PA, van der Linden CJ, Greep. IM. Cellular cytotoxicity generated in a canine miked kidney lymphocyte cell culture. Tissue Antigens $1981 ; 18: 326$.

Gilbert SF, Migeon BR. D.Valine as a selective agent for normal human and rodent epithelial cells in culture. Cell 1975; $5: 11$.

Gilbert SF, Migeon BR. Renal enzymes in kidney cells selected by D-waline medium. J Cell Physiol 1977 ; 92: 161 .

Hart DNJ, Fabre JW. Major histocompatibility complex antigens in rat kidney, ureter and bladder. Transplantation 1981; $31: 318$.

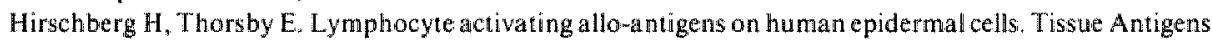
$1975 a ; 6: 183$.

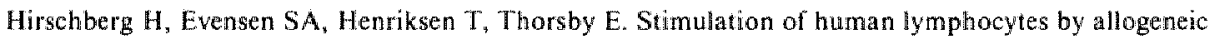
endothelial cells in vitro. Transplantation $1975 \mathrm{~b} ; 19: 495$.

Jaffe EA, Hoyer LW, Nachman RL. Synthesis of antihemophilic factor antigen by cultured human endothelial cells. J Clin Invest 1973; 52: 2757.

Lifton J, DeWolf WC, Wilcox C, Miller $J$. The primed canine MLC, allograft immunity in vitro. Regulatory mechanisms in lymphocyte activation. ed. Lucas D. Academic Press, New York 1977 ; p 400 .

Main RK, Jones MJ, Birnbaum J, Kountz SL. Mixed culture response of yymphocytes to dissociated kidney cells. Transplantation 1975; $20: 92$.

Mashimo S, Sakai A, Ochiai T, Kountz SL. The mixed kidney cell-lymphocyte reaction in rats. Tissue Antigens 1976; 7:291.

Moraes JR, Stastny P. A new antigen system expressed in human endothelial cells. J Clin Invest 1977 ; 60:449.

Pawelec G, Davies HfS, Steele C, White D, Brons C. Stimulation of lymphocyte proliferation in vitro by cultured nonly mphoid tissue cells which do not express la-like antigem. Transplant Proc 1979 11: 1095.

Pawelec G, Dawies HIfS, Pearson JD, Steele C, Brons G. Stimulation of lymphocyte proliferation by nonlymphoid porcine tissue cells. Tissue Antigens 1979; 14:367.

Poste G. Tissue dissociation with proteolytic enzymes. Adsorption and activity of enzynes at the cell surface. Exp Cell Res 1971; 65: 359.

Sakai A, Tanaka S, Kountz SL. Liver and immune responses. IV. Characteristics of the liwer cell-lymphocyte interaction. Transplantation 1978; 25: 110 .

Schellekens PThA, Eijswoogel V P. Lymphocyte transformation in vitro. III. Mechanism of stimulation in the mixed lymphocyte culture, Clin Exp Immunol 1970; 7:229.

Steinman RM, Kaplan G, Witmer MD, Cohn ZA. Identification of a novel cell type in peripheral lymphoid organs of mice. J Exp Med 1979; 149: 1.

Steinmuller D, Tyler JD, David CS. Cell-mediated cytotoxicity to non-MHC alloantigens on mouse epidermal cells. $1 . \mathrm{H}-2$ restricted reactions among strains sharing the $\mathrm{H}-2^{\mathrm{k}}$ haplotype. $\mathbb{A}$ Immunol 1981 : 26: 1747 . 
Thompson JS, Overtin W, Severson CD, al. Demonstration of granulocyte, monocyte and endothelial cell antigens by double fluorochromatic microcytotoxicity testing. Transplant Proc 1980: 12: 26.

Vegt PA. Buurman WA, van der Linden CJ. Daemen AJJM, Greep JM, Jeekel I Cell-mediated cytotoxicity toward canine kidney epithellial cells. Transplantation 1982: 33: 465 .

Vetto RM, Burger DR. Endothelial cell stimulation of allogeneic lymphocytes. Transplantation 1972; 4 : 652. 



\section{Chapter 6 \\ Cellular cytotoxicity generated in a canine mixed kidney lymphocyte cell culture}

\subsection{Introduction}

The in vitro generation of cytotoxic T lymphocytes (CTL) with lymphocytes as stimulator cells has been studied extensively. Non-lymphoid cells, have seldom been used for in vitro generation of CTL. Steinmuller and Wunderlich (1976) have observed in vitro generation of CTL in mixed dissociated murine tail epidermal cell lymphocyte cultures. Murine epidermal cells have been shown to be very effective primary and secondary stimulator cells for both lymphocyte proliferation and generation of CTL.

However, lymphocyte stimulation by non-lymphoid cells has been reported for: kidney cells (Main 1975, Mashimo 1976, Lifton 1977, and Sakai 1977), heart cells (Sakai 1977), epidermal cells (Cochrum 1971, Levis 1972, Sakai 1977, Tanaka 1979) and endothelial cells (Vetto 1972, Hirschberg 1974).

Cellular cytotoxicity ind uced by non-lymphoid tissue cells as kidney epithelial cells offers new possibilities for in vitro study of tissue specific cellular cytotoxicity for matching and for post-transplant monitoring. Porcine cultured kidney epithelial cells have been reported to stimulate both allogeneic lymphocytes and lymphocytes of MHC identical animals (Pawelec 1979). It has been suggested that class II antigens and non-MHC tissue specific antigens on porcine kidney cells are responsible for lymphocyte stimulation.

Here, we report that cultured canine kidney epithelial cells are very effective stimulators for the induction of cytotoxic cells.

\subsection{Materials and Methods}

\section{Leucocytes}

Blood samples were taken from closely related, one haplotype mismatched, typed beagles of our colony. Leucocytes were prepared by the classical technique with Lymphoprep (Nyegaard, Oslo, Norway). The leucocyte suspensions obtained consisted of 30-70\% lymphocytes (Buurman 1982).

\section{Kidney epithelial cells}

Kidney epithelial cells were obtained by ex vivo perfusion with a $0.25 \%$ trypsin 
solution after unilateral nephrectomy. The dissociated corter cells were sieved, washed, and a single cell suspension was obtained. The primary cultures were started with MEM + newborn calf serum + lactalbumin + Hepes and antibiotics. Only second to fourth passage cells were used.

The cultured cells were epithelial in morphological appearance. Furthermore, immunofluorescence with anti-F VIII disclosed the presence of endothellal cells, and D-valine MEM was used as selective medium for epithelial cells (Gilbert 1975). More extensive details about the culture conditions and the epithelial character of the cultured cells will be given elsewhere (Vegt 1982).

\section{Mixed cell cultures and cytotoxic assays}

Mixed cell cultures were set up in Lux (Newbury Park, Cal., USA) plastic tissue culture flasks $\left(25 \mathrm{~cm}^{2}\right)$. All cultures consisted of $10^{7}$ responder leucocytes in a total volume of $20 \mathrm{ml}$ RPMI - 1640 + hepes + serum + antibiotics. Graded numbers of irradiated (2500 rad) stimulator cells, $10^{4}-10^{7}$, both leucocytes and cultured kidney cells were used. Cytotoxicity was assayed on day 6 of culture.

Target cells were PHA stimulated lymphoblasts ( 3 days stimulation period) and cultured kidney cells. The target cells were labeled with ${ }^{51} \mathrm{Cr}\left(\mathrm{Na}_{2}{ }^{51} \mathrm{CrO}_{4}\right.$, Amersham, England). The maximum release obtained with a detergent was $90-95 \%$ of total radio activity contained by the cells. Spontaneous release over the optimal incubation period of $6 \mathrm{~h}$ was $10-20 \%$. Cytotoxicity was assayed in round bottom microtiter plates, on day 6 , the effector cells and labeled target cells were transferred into the microtiter plates. In all instances, $2.5 \times 10^{3}$ target cells were used, with varying amounts of effector cells in a total volume of $0.2 \mathrm{ml} /$ well. The cell lysis was assayed by measurement of the radioactive supernatant harvested with absorbtion cartridges (Skatron, Oslo, Norway). The percentage of specific release was calculated as follows: per cent specific release $=$

$$
\frac{\text { c.p.m. in exp. group }}{\text { c.p.m. released with detergent }- \text { spont. released c.p.m. }} \times 100 \%
$$

Lymphocyte stimulation of the cultures mentioned above was measured on day 6 after a 4 h incubation of $10^{5}$ cells in a microtiter plate with $1 \mu \mathrm{Ci}^{3} \mathrm{HTdR}$ in the usual way.

\subsection{Results and Discussion}

Mixed kidney cell lymphocyte cultures and mixed lymphocyte cultures were performed with cells of one haplotype mismatched beagles. The cultured kidney epithelial cells, virtually free of endothelial cells and fibroblasts, originated from unilateral 
Table I Generation of cellular cy totoxicity in a cane mixed kidney cell lencocyteculture

\begin{tabular}{|c|c|c|c|c|c|}
\hline \multirow{3}{*}{$\begin{array}{l}\text { Stimulator: } \\
\text { Responder ratio }\end{array}$} & \multirow{3}{*}{$\begin{array}{l}\text { Lymphocyte } \\
\text { stimulation } \\
\text { c.p.m. }\end{array}$} & \multicolumn{4}{|c|}{ Cellular cytotoxicity } \\
\hline & & \multicolumn{2}{|c|}{$\begin{array}{l}\text { Target cells from } \\
\text { stimulator cell donor }\end{array}$} & \multicolumn{2}{|c|}{$\begin{array}{l}\text { Target cells from } \\
\text { responder cell donor }\end{array}$} \\
\hline & & $\begin{array}{l}\text { PHA blast } \\
\text { target }\end{array}$ & $\begin{array}{l}\text { kidney cell } \\
\text { target }\end{array}$ & $\begin{array}{l}\text { PHA blast } \\
\text { target }\end{array}$ & $\begin{array}{l}\text { kidney cell } \\
\text { target }\end{array}$ \\
\hline $\mathbb{1}: \quad 2$ & 4,070 & $-11 \%$ & $2 \%$ & n.t. ${ }^{\circ}$ & n.t. \\
\hline I: $\quad 10$ & 4,118 & $-7 \%$ & $14 \%$ & $-3 \%$ & $0 \%$ \\
\hline $1: \quad 20$ & 7,345 & $38 \%$ & $36 \%$ & $-2 \%$ & $2 \%$ \\
\hline 1: 100 & 3,703 & $4 \%$ & $20 \%$ & $-1 \%$ & $2 \%$ \\
\hline 1: 200 & 3,383 & $-5 \%$ & $-9 \%$ & $3 \%$ & $-6 \%$ \\
\hline $1: 1000$ & 2,977 & $-2 \%$ & $3 \%$ & n.t. & $\mathrm{n} . \mathrm{t}$ \\
\hline \multicolumn{6}{|c|}{$\begin{array}{l}\text { Stimulatior and responder cells differed by one DLA haplotype. } \\
\text { Effector: Target ratio; } 80: 1 \text {. } \\
\text { n.t.: not tested. }\end{array}$} \\
\hline
\end{tabular}

nephrectomized beagles. This experimental approach permitted us to compare the generation of CTL in both MKCL and MLC. Furthermore this procedure offered the possibility to compare the activity of generated cytotoxic cells toward both PHA stimulated lymphoblasts and kidney cells of the stimulator.

Table 1 shows the data of a typical MKLC experiment. Cytotoxic cells were generated in a MKLC at stimulator: responder ( $:$ R) ratios of $1: 10-1: 100$. Optimal cytotoxicity was generated at a $S: R$ ratio of $1: 20$. Autologous and third party killing

Table 2 Generation of cellular cytotoxicity in a canine mixed lymphocyte culture

\begin{tabular}{|c|c|c|c|c|c|}
\hline \multirow{3}{*}{$\begin{array}{l}\text { Stimulator: } \\
\text { Responder ratio }\end{array}$} & \multirow{3}{*}{$\begin{array}{l}\text { Lymphocyte } \\
\text { stimulation } \\
\text { c.p.m. }\end{array}$} & \multicolumn{4}{|c|}{ Cellular cytotoxicity ${ }^{b}$} \\
\hline & & \multicolumn{2}{|c|}{$\begin{array}{l}\text { Target cells from } \\
\text { stimulator cell donor }\end{array}$} & \multicolumn{2}{|c|}{$\begin{array}{l}\text { Target cells from } \\
\text { responder cell donor: }\end{array}$} \\
\hline & & $\begin{array}{l}\text { PHA blast } \\
\text { target }\end{array}$ & $\begin{array}{l}\text { kidney cell } \\
\text { target }\end{array}$ & $\begin{array}{l}\text { PHA blast } \\
\text { target }\end{array}$ & $\begin{array}{l}\text { kidney cell } \\
\text { larget }\end{array}$ \\
\hline 1: $\quad 1$ & 13,254 & $28 \%$ & $37 \%$ & $2 \%$ & $-4 \%$ \\
\hline 1: & 14,411 & $38 \%$ & $41 \%$ & $-3 \%$ & $-5 \%$ \\
\hline 1: 10 & 2,876 & $22 \%$ & $14 \%$ & $-6 \%$ & $-6 \%$ \\
\hline 1: 20 & 1,815 & $-7 \%$ & $0 \%$ & $-5 \%$ & -30 \\
\hline 1: 100 & 2,238 & $-11 \%$ & $-2 \%$ & $\mathrm{n} . \mathrm{t}^{\mathrm{c}}$ & n.t. \\
\hline 1: 200 & 2,350 & $-11 \%$ & $0 \%$ & n.t. & n.t. \\
\hline $1: 1000$ & 1,250 & $-9 \%$ & 49 & n.t. & n.t. \\
\hline
\end{tabular}

"Stimulator and responder cells differed by one DLA haplotype.

- Effector: Target ratio; $80: 1$.

c n.t.: not tested. 
was negligible in all experiments (data not given). Lymphocyte stimulation measured as ${ }^{3} \mathrm{HTd} R$ uptake was also optimal at a $S: R$ ratio of $1: 20$. The cytotoxicity toward PHA stimulated lymphoblasts and cultured kidney cells appeared to differ in all experiments performed. Cellular cytotoxicity generated toward cultured kidney cells was observed at $S: R$ ratios of $1: 10$ and $1: 100$ whereas the lysis of PHA stimulated lymphoblasts was not significant at these $S: R$ ratios.

Cytotoxic cells generated in a classical mixed lymphocyte culture showed optimal cytotoxicity at a $S: R$ ratio of $1: 2$ (Table 2). Cytotoxic cells were not observed at $S: R$ ratios of 1:20 and lower. The cytotoxicity generated did not differ very much for PHA stimulated lymphocyte targets and kidney cell targets. Also in this experiment the optimal ${ }^{3} \mathrm{HTdR}$ uptake was observed at the same $\mathrm{S}: \mathrm{R}$ ratio at which maximal cytotoxicity was generated.

As shown in Table 3, cytotoxicity of cytotoxic cells generated in both MKLC and MLC toward kidney cells and PHA stimulated lymphoblasts was optimal at target: effector cell ratios of $1: 80$ as used in Tables 1 and 2 .

The above mentioned results show that cellular cytotoxicity can be generated in MKLC. Daniel \& Edwards (1975) have described degeneration of kidney cell monolayers cultured with allogeneic porcine lymphocytes. They concluded that cytotoxic cells generated in such cultures were responsible for the degeneration of the kidney cell monolayers, which can be explained by the present results. It can be concluded that cultured kidney epithelial cells, which are devoid of endothelial cells with known presentation of class II antigens, are very effective stimulator cells for both generation of CTL and lymphocyte proliferation. These results are not in agreement with Lafferty's (1980) model of 'immunogenicity of foreign tissues', since in our experimental situation cytotoxic cells are generated without lymphoid cells of the stimulator being present.

Ourdata are in accordance with the data of Steinmuller \& Wunderlich (1976) who showed that allogeneic murine epidermal cells could effectively stimulate generation of CTL. They observed that generation of CTL occurred preferentially at low $S: R$ ratios (1:50-1:500). Here we showed that also in the MKLC, CTL are generated at low $\mathrm{S}$ : R ratios. Lymphocyte stimulation with porcine kid ney cells has been reported

Table 3 Effector to target cell ratio for MKLC and MLC generated cellular cytotoxicity Erfector:

Target cell ratio

\begin{tabular}{rllll}
\cline { 2 - 4 } & $\begin{array}{l}\text { PHA blast } \\
\text { target }\end{array}$ & $\begin{array}{l}\text { Kidney cell } \\
\text { target }\end{array}$ & $\begin{array}{l}\text { PHA blast } \\
\text { target }\end{array}$ & $\begin{array}{l}\text { Kidney cell } \\
\text { target }\end{array}$ \\
\hline $160: 1$ & n.t. & n.t. & $68 \%$ & $80 \%$ \\
$80: 1$ & $30 \%$ & $28 \%$ & $60 \%$ & $70 \%$ \\
$40: 1$ & $28 \%$ & $27 \%$ & $60 \%$ & $76 \%$ \\
$20: 1$ & $10 \%$ & $16 \%$ & $54 \%$ & $55 \%$ \\
\hline
\end{tabular}

Percentage specific release is given.

n.t.: not tested. 
to be optimal at a $\mathrm{S}: \mathrm{R}$ ratio of $1: 16$ (Pawelec 1979). Whether the decreased response of the MKLCat higher $S$ : R ratios $(1: 20)$ revealed a physiological phenomenon or an in vitro artefact remains to be studied. A deterioration of the culture medium by higher numbers of cultured kidney cells could explain the phenomenon, since kidney cells do not show an 'immediate' interphase death after irradiation. Furthermore, it cannot be ruled out without additional experiments that the cultured kidney cells consume $T$ cell growth factors and inhibit the proliferative $T$ cell response in this manner.

The nature of the cytotoxic cells generated during the MKLC is a subject of further study. It is proposed that CTL are generated, but it cannot be ruled out that natural killer cells or other cellular cytotoxic mechanisms a re also involved. The difference in specificity of cytotoxic cells generated in MKLC toward PHA stimulated lymphoblasts and kidney cells that might be suggested by the present experiments, may have important implications for clinical organ grafting.

Recently, we observed that CTL generated in a canine MLC recognize different target antigens on PHA stimulated lymphoblasts and on cultured kidney cells (Vegt 1982). The data presented here support the latter data, however, without additional data, other explanations are to be considered equally probable. Steinmuller (1981) has reported $\mathrm{H}-2$ restricted cell mediated cytotoxicity directed toward non $\mathrm{H}-2$ alloantigens expressed preferentially on mouse epidermal cells, a phenomenon which could be analogous to the phenomenon providing the basis for our data. Further investigations are being carried out in our laboratory analysing the specificity of cytotoxic cells cultured under limiting dilution conditions to clarify the specificity of cytotoxic cell clomes generated in MKLC.

\subsection{Summary}

Canine cultured kidney epithelial cells were stimulatory to allogeneic lymphocytes in mixed kidney cell lymphocyte cultures (MKLC). Generation of cytotoxic cells, cytotoxic for both kidney cells and PHA stimulated lymphoblasts of the stimulator have been observed. Lymphocyte stimulation and generation of CTL occurred in the MKLC at lower stimulator: responder cell ratios as in the mixed lymphocyte culture (MLC).

\section{Acknowledgements}

The authors wish to thank Prof. Dr. J. Jeekel for helpful discussions. We would also like to acknowledge Mrs. A.J.J.M. Daemen for skillful technical assistance and Miss $M$. van den Berg for secretarial assistance.

This chapter has been published in Tissue Antigens.

W.A. Buurman, P.A. Vegt, C.J. v.d. Linden and J.M. Greep. Cellular cytotoxicity generated in a canine mixed kidney lymphocyte cell culture. Tissue Antigens 1981; 18: 326 . 


\subsection{References}

Butrman W Vegt PA, Groenewegen G, Linden CJ van der, Jeunhomme GMAA. Aralysis of buoyant density of canine perpheral blood leucocytes in PVP-silica (Porcoli) density gradients. Vet Immunol Imrnunopathol 1982: 3: $\$ 47$.

Cochrum KC. Main RK, Kountz SL. A new matching techiquê: The mixed skin cell leucacyte reaction (MSIR). Surgery 1971:70:97.

Daniet MR, Edwards MJ. Interaction of pig lymphocytes with allogeneic kidney cells in vitro. Brit J exp Path 1975; 56: 349 .

Gibert $S G$, Migeon BR. D-Valine as a selective agent for normal human and rodent apithelial cells in culture. Cell 1975; $5: 11$.

Hirschberg H, Evensen SA, Henriksen T, Thorsby E. Stimulation of human lymphocytes by allogeneic endothelial cells in vitro. Tissue Antigens 1974; $4: 257$.

Lafferty KJ. Immunogenicity of foreign tisstes. Transplantation 1980; $29: 179$.

Levis RW, Miller AE. Leucocyte skin cultures as a measure of histocompatibility in man. Lancet 1972 ; $11: 357$.

Lifton J, DeWolf WC, Wilcox $C_{4}$ Miller I. The primed canine MLC: allograft immunity in vitro. In Regulatory Mechanisms in Lymphocyte Activation, ed. Lucas, D. Academic Press, New York. $1977 ; 400$.

Main RK, Jones MJ, Birnbaum J, Kountz SL. Mixed culture response of lymphocytes to dissociated kidney cells. Transplantation 1975; 20 : 92.

Mashimo S, Sakai A, Ochial T, Kounta SL. The mixed kidney cell-lymphocyte reaction ín rats. Tissue Antigens 1976:7:291.

Pawelec $G$, Davies HftS, Steel C, White D, Brons $G$. Stimulation of lymphocyte proliferation in vitro by cultered non-lymphoid tissue cells which do not express la-like antigen. Transplant Proc 1979; 11: 1095.

Sakai A, Kasthiwa bara H, Taha M. Kountz SL. Role of organ-specific antigen in the Ag-B compatiblegraft rejection. Transplant Proc $1977 ; 9: 629$.

Steinmuller D, Wunderlich JR. The use of freshly explanted mouse epidermall cells for the in vitro induction and detection of cell rhediated cytotoxicity. Cell. Immunol. 1976; 24: 146.

Steinmuller D, Wunderlich JR, David CS. Cell-mediated cytotoxicity to non-M HCalloantigens on mouse epidermal cells. 1. H-2 Restricted Reactions among Strains Sharing the H-2k Haplotype. I $\mathbb{I m m u n o l}$ $1981 ; 126: 1747$.

Tanaka $S$, Sakai A. Stimulation of allogeneic lymphocytes by skin epidermal cells in the rat. Transplantation 1979; $27: 194$.

Vegr PA, Buurman WA, w Linden CJ, Daemen AJJM, Greep JM, Jeekel J. Cell mediated cytotoxicity toward canine kidney epithelial cells. Transplantation 1982; 33:465.

Vetto RM, Burger DR. Endothelial cell stimulation of allogeneic lymplucytes. Transplantation 1972 ; $14: 652$. 


\section{Chapter 7}

\section{Cellular reactivity after transplantation}

\subsection{Introduction}

Allograft rejection is mediated by humoral and cellular mechanisms. Many approaches have been applied to study the role of the humoral and cellular components of allograft rejection. The detection of direct cell mediated cytotoxicity after transplantation gives inconsistent results (Grunnet 1978, Kovithavongs 1978, Stiller 1976). There are several ways to explain the absence of direct cell mediated cytotoxicity in peripheral blood during rejection episodes. It might be that cytotoxic effector cells do not play an important role in allograft rejection and therefore don't circulate in sufficient numbers to be detected. The role of cytotoxic $T$ cells in transplantation immunity has been disputed by Loveland. He showed with reconstitution studies in adult thymectomized, irradiated and bone marrow reconstituted animals (ATXBM) that not the cytotoxic $T$ cells, but cells correlated with the helper effect and DTH response, are involved in cellular rejection of the graft (Loveland 1981). These findings have been confirmed by Dallman, who found that $T$ helper cells and not cytotoxic $\mathrm{T}$ cells, injected into ATXBM animals were able to reject skin grafts (Dallman 1982). Most of the studies on cellular reactivity after transplantation however suggest a major role of cytotoxic $T$ cells in the rejection proces. Characterization of cells infiltrating in rejected grafts clearly showed that most of the cells are of the T cell lineage (Carpenter 1981, Tilney 1979, von Willebrand 1978). A high and specific cytotoxicity toward donor type target cells has also been demonstrated. If the cytotoxic T cells are important in the rejection of allografts, the question remains why they are not easily detectable in the circulation of a recipient of a transplant during a rejection episode.

The homing of cytotoxic $T$ lymphocytes in the graft during rejection is often mentioned to explain the lack of circulating cytotoxic T cells after transplantation. Ascher even suggested that not only homing of cytotoxic effector cells in the graft occurs but that the maturation of effector cells also takes place in the transplanted graft. She proposed that the enriched population of specially sensitized $T$ cells in the graft is the result of infiltration of a few sensitized cells which expand after entering the graft independent of the contribution of the host (Ascher 1983).

An important additional aspect can be that the targets used for the detection of CTL do not carry all antigens recognized by circulating CTL. Cell mediated cytotoxicity toward non-lymphoid antigens might also be inwolved in kidney graft rejection. We previously showed that CTL. recognize antigens on canine kidney epithelial cells, which are not present on PHA stimulated lymphoblasts (Vegt 1982 ). Since 
Cytotoxicity is generally detected with PHA stimulated lymphoblasts or spleen cells the inability to detect kidney specific cytotoxicity could be a reason for the inconstant results of measuring direct cytotoxicity after transplantation.

We investigated whether the homing of CTL could be responsible for the lack of direct cytotoxicity in peripheral blood during rejection episodes. An adsorption model in which primed lymphocytes were adsorpted on stimulator leucocyte monolayers has been used to study the affinity of CTL and their precursors toward donor antigens. Adsorption studies have been performed with effector cells generated in MLC. The primed leucocytes before adsorption (non-adsorbed) as well as the nonadherent cell fractions have been tested for cytotoxicity. The in vitro results were verified in an in vivo kidney transplantation model in the dog. Precursor CTL could be detected during the rejection episode, in absence of a direct cell mediated cytotoxicity.

\subsection{Materials and methods}

\section{Animals}

Closely bred beagles of the colony of the University of Limburg were used for all experiments.

\section{Preparation of leucocytes}

Heparinized blood ( $5 \mathrm{IU} / \mathrm{ml}$ ) was collected under sterile conditions by puncture of the external jugular vein. Leucocytes were prepared by the technique of Bøyum with gradient centrifugation on Lymphoprep (Nyegaard, Oslo, Norway). The leucocyte suspensions obtained, consisted of $30-70 \%$ lymphocytes.

\section{In vitro generation of cytotoxic $T$ cells}

Leucocyte suspensions as described above, were sensitized against irradiated leucocytes of one haplotype mismatched beagles. The cell cultures were prepared in RPM I- 1640 supplemented with $10 \%$ heat inactivated pooled dog serum, $1001 \mathrm{U} / \mathrm{m}]$ penicillin and $100 \mu \mathrm{g} / \mathrm{ml}$ streptomycin. Cultures were set up in tissue culture flasks containing $10^{7}$ responder and $10^{7}$ irradiated stimulator cells in $20 \mathrm{ml}$ of culture medium. The flasks were placed under an angle of $45^{\circ}$ at $38 \mathrm{C}$ in a humified atmosphere of $5 \% \mathrm{CO}_{2}$ in air. 
Cytotoxicity of cells sensitized in vitro or in vivo was measured with the ${ }^{51} \mathrm{Cr}$ release assay. Target cells consisted of lymphocytes cultured 3 days with phytohaemagglu-

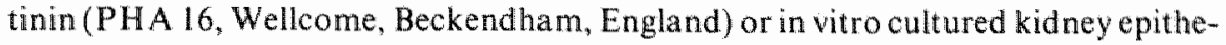
lial cells. $10^{\circ}$ target cells were labeled with $200 \mu \mathrm{Ci} \mathrm{Na} 2{ }^{51} \mathrm{CrO}_{4}$ for 45 minutes at $38 \mathrm{C}$, after labeling the cells were washed 3 times in RPMI-1640 with serum. The lymphocyte mediated cytotoxicity assay was performed in round bottom microtiter plates, containing $2.5 \times 10^{3}$ target cells per well and different numbers of effector cells, resulting in effector target cell ratios of $20: 1,40: 1$ and $80: 1$. The cultures were set up in quadruplicate and incubated for 4 hours at $38 \mathrm{C}$ in a humified atmosphere containing $5 \% \mathrm{CO}_{2}$ in air. After incubation the supernatant was collected by cellulose acetate absorption cartridges (Skatron, Oslo, Norway) and the ${ }^{5} \mathrm{Cr}$ release was rneasured in a gamma-counter. The percentage of specific cytotoxicity was calculated according the following formula:

$\frac{\text { experimental release }- \text { spontaneous release }}{\text { maximum release }- \text { spontaneous release }} \times 100 \%=\%$ specific lysis

\section{Preparation of leucocyte monolayers}

Adsorption of in MLC generated cells was performed on leucocyte monolayers prepared by the method of Silva and Landazuri (1978). In brief $1 \mathrm{ml}$ poly-L-lysine $(50 \mu \mathrm{g} / \mathrm{ml}$ in PBS mol. weight. 30.000 Sigma, MO.) was added to a $30 \mathrm{~mm} \varnothing$ tissue culture petri dish for 1 hour at $22 \mathrm{C}$. After a wash with phosphate buffered saline (PBS), a $1 \% \mathrm{v} / \mathrm{v}$ suspension of fresly prepared chicken red blood cells (CRBC) was applied to the dish, incubated for 10 minutes at $22 \mathrm{C}$ followed by repeated washings. The CRBC were fixed with $0.2 \%$ glutaraldehyde for 10 minutes at $4 \mathrm{C}$ and covered fimally with $0.1 \mathrm{M}$ glycine. Subsequently $1 \mathrm{ml}$ PHA 15 (Wellcome, Beckendham, England) was added to the monolayers and incubated for 30 minutes at $38 \mathrm{C}$. Leucocytes used for the monolayer were added to the PHA covered monolayer of CRBC and adhered to the lectin bridges of the PHA. After incubation with leucocytes the interstices between leucocytes were cowered with syngeneic red blood cells to prevent aspecific binding to PHA of the cells applied to the monolayer for the adsorption studies. The monolayers formed by this procedure were macroscopically and microscopically confluent.

\section{Immuno adsorption on leucocyte monolayers}

Stimulated leucocyte suspensions were applied to the monolayers and incubated for 1 hour at $38 \mathrm{C}$. The fraction of non-adherent cells was obtained by careful aspiration 
of the supernatant after gentle swirling the petri dish for about 10 seconds. The non-adherent fractions were tested for cytotoxicity as described above.

\section{Kidney epithellial cell culture}

The kidney biopsy was minced and trypsinated with a $0.25 \%$ trypsin solution. The dissociated cells were sieved, washed and a single cell suspension was obtained. The culture was started with MEM + newborn calf serum + lactalbumin + Hepes + antibiotics. The cultured cells were epithelial in appearance. Extensive details about culture conditjons and the epithelial character have been reported previously (Vegt $\left.1982^{b}\right)$.

\section{Operation}

Anesthesia consisted of fentanyl base and Na-pentobarbital intra-venously. After intubation the dogs were respirated with a $\mathrm{O}_{2} / \mathrm{N}_{2} \mathrm{O}$ gas mixture. Through a midline incision the abdomen was opened and the right or left kidney was removed. Only one kidney was used from each donor for the transplantation experiments. This permitted us to use the donor as blood donor for the monitoring assay. A wedge biopsy of about $0.5 \times \mathbb{1 ~ c m}$ was taken from the donor kidney. This was used for in vitro culture of donor kidney cells. After harvesting, the kidney was flushed with 100-300 $\mathrm{ml}$ of Euro Collins solution at $4 \mathrm{C}$ and the kidney was implanted in the right fossa illaca of the recipient.

\section{Thoracic duct drainage}

A longitudinal incision along the jugular vein was made. The jugular vein was freed till its ending in the left subclavian vein. The thoracic duct was ligated at the entrance into the subclavian vein and a silicone $T$ drain was inserted into the thoracic duct. The drain was tunneled a few centimetres under the skin, the efferent leg of the silicone loop was introduced into the right external jugular vein via a second incision. This permitted continuation of the lymph flow and prevented clotting of the drain.

\subsection{Results}

\section{Adsorption of CTL and their precursors}

The affinity of CTL generated in a MLC toward donor antigens was studied with adsorption on stimulator type leucocyte monolayers. Adsorption of CTL of a six day MLC on a stimulator specific leucocyte monolayer reduced cytotoxicity for about 
$80 \%$ in 6 consecutive experiments, whereas adsorption on a third party monolayer reduced cytotoxicity for only $13 \%$. This proved that CTL ad here toward stimulator antigens in a antigen specific way.

Similaradsorption experiments were performed during the generation of CTL in a MLC. Adsorptions have been performed on day 3, 4 and 5 of the initial culture. Figure 1 shows in a representative experiment that adsorption reduced cytotoxicity $80-90 \%$. To study whether also primed precursor CTL show affinity toward stimulator antigens, the non-adherent cell fractions after adsorption were tested for the presence of primed precursor CTL by restimulation with irradiated stimulator leucocytes. Restimulation studies of these non-adherent cell suspensions showed a return to near normal cytotoxicity values within 3 days of restimulation. Non-adherent cells obtained after adsorption on day 3 were restimulated for 3 days, non-adherent cells from day 4 were restimulated for 2 days and the cell suspensions obtained after adsorption on day 5 of the initial culture were finally restimulated for $\downarrow$ day. This

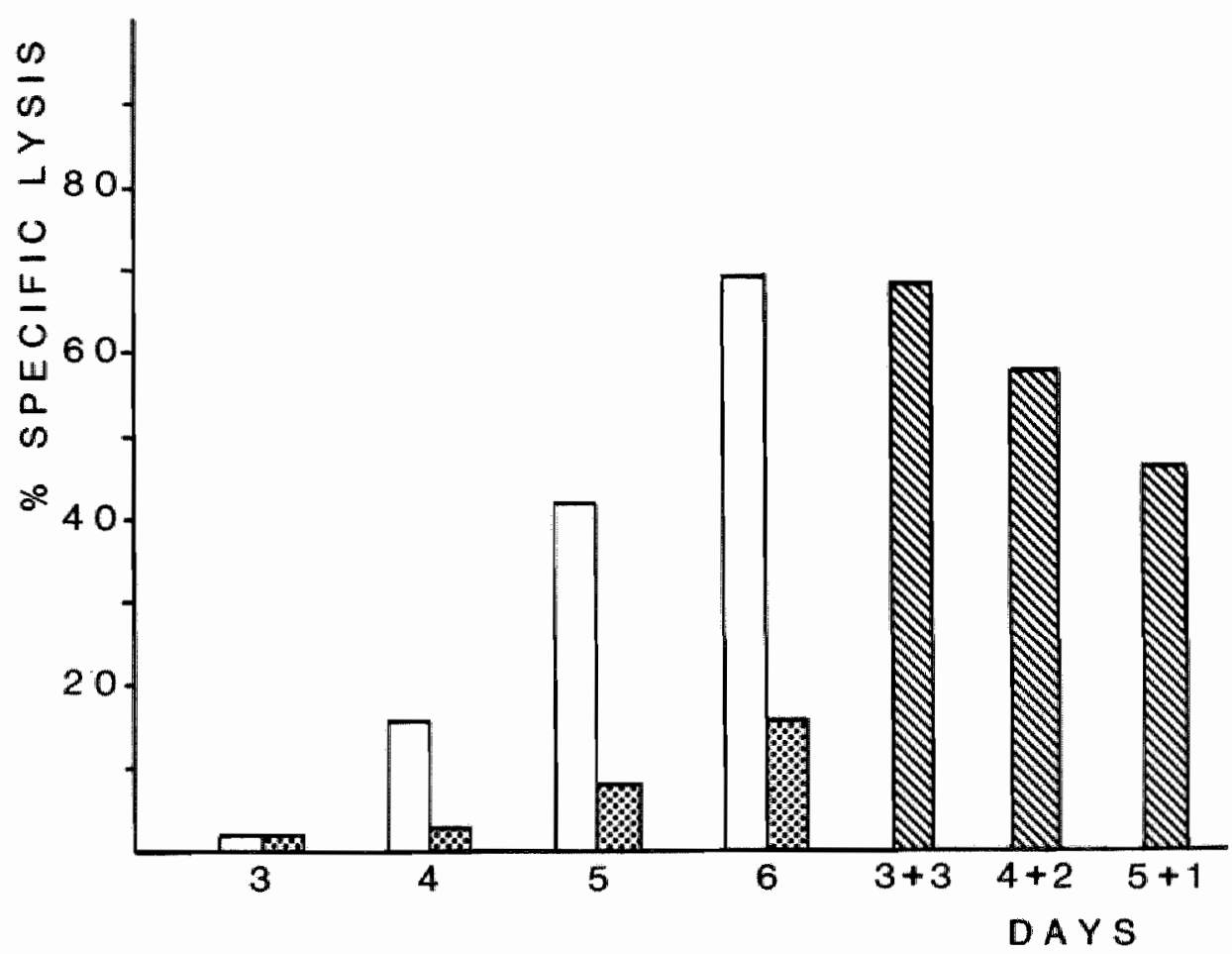

Figure I Cell mediated cytotoxicity of untreated, non-adherent and restimulated non-adherent affector cells generated in MLC. The open bars represent cytotoxicity of untreated effector cells measured on days 3-6 of MLC. The dotted bars give cy totoxicity of the non-ad herent fraction of the denticall cell suspensions after adsorption on a monolayer of stimulator cells. The hatched bars represent cytotoxicity of the latter cell suspensions after restimulation with stimulator cells for 3,2 or $\|$ day uptill a culture period of six days 


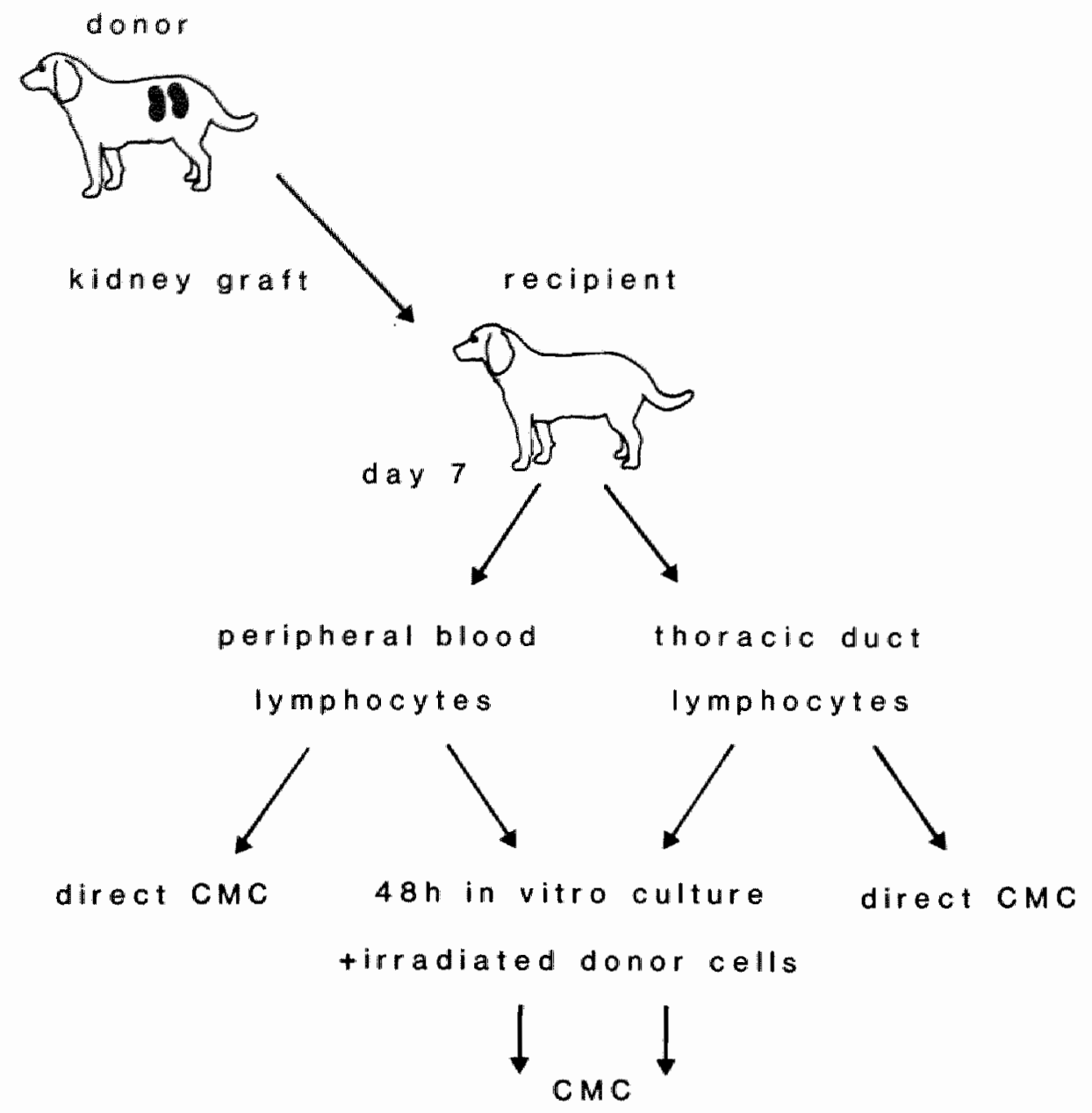

Figure 2 A schematic representation of the in vivo experiment

implicates that the cytotoxicity of the restimulated cell fractions was determinated on day 6 of the initial culture and therefore comparable with cytotoxicity after normal 6 days generation of CTL in a MLC.

Cytotoxicity of the restimulated cell suspensions did not differ significantly from the cytotoxicity generated in a normal MLC. This indicates that the non-adherent cell fractions were rich in primed precursor CTL. In other words a substantial fraction of primed precursor CTL appeared to lack affinity toward donor antigens. 
The in vitro studies showed that a substantial fraction of primed precursor CTL lack affinity to stimulator leucocyte antigens. This might implicate that this fraction of primed precursor CTL does not home in the transplanted graft and circulates in the host. Since Gowans (1964) demonstrated the recirculation route of lymphocytes from blood into peripheral lymphoid tissues and back to the circulation via the thoracic duct, we studied the presence of primed precursor CTL in peripheral blood as well as thoracic duct lymph. During the rejection episode, leucocytes of peripheral blood and thoracic duct lymph were studied for the presence of CTL and their precursors (Figure 2). To detect more subpopulations of CTL which may show cytotoxicity, kidney epithelial cells, which are known to present MHC as well as non-M HC target antigens, were used as sensitive targets in these assays.

Table 1 shows that a direct cell mediated cytotoxicity during first set renal allograft rejection in non-immunosuppressed dogs was only marginally observed. We used the standard $6 \mathrm{~h}$ incubation period of effector and target cells. Cytotoxicity toward donor kidney cells on day 7 after transplantation varied up to $8 \%$ specific lysis for peripheral blood leucocytes. Thoracic duct lymphocytes showed a cytotoxicity from I to $9 \%$ specific lysis in the direct cell mediated cytotoxicity assay. In contrast to this low cytotoxicity a serious rejection was observed at laparotomy performed $24 \mathrm{~h}$ later when the dogs were sacrificed.

Precursor CTL were studied after in vitro restimulation of the identical cell suspensions used on day 7 after transplantation for the direct cellular cytotoxicity assays. Both cell suspensions from thoracic duct lymph and peripheral blood were

Table I Cell mediated cytotoxicity toward donor kidney cells after transplantation

\begin{tabular}{|c|c|c|c|c|c|}
\hline \multirow[t]{2}{*}{ Dog nr. } & \multirow[t]{2}{*}{$\begin{array}{l}\text { Effector } \\
\text { cells }\end{array}$} & \multicolumn{2}{|c|}{ Direct CMC } & \multicolumn{2}{|c|}{$\begin{array}{l}\text { CMC after restimulation } \\
\text { in vitro for } 2 \text { days }\end{array}$} \\
\hline & & Blood & $\begin{array}{l}\text { Thoracic } \\
\text { duct }\end{array}$ & Blood & $\begin{array}{l}\text { Thoracic } \\
\text { duct }\end{array}$ \\
\hline 1 & $\begin{array}{r}2.10^{5} \\
10^{5} \\
5.10^{4}\end{array}$ & $\begin{array}{r}3 \% \\
-3 \% \\
3 \%\end{array}$ & $\begin{array}{l}9 \% \\
3 \% \\
1 \%\end{array}$ & $\begin{array}{l}74 \% \\
75 \% \\
53 \%\end{array}$ & $\begin{array}{l}55 \% \\
58 \% \\
30 \%\end{array}$ \\
\hline 2 & $\begin{array}{r}2.10^{5} \\
10^{5} \\
5.10^{4}\end{array}$ & $\begin{array}{l}8 \% \\
8 \% \\
7 \%\end{array}$ & $\begin{array}{l}3 \% \\
0 \% \\
6 \%\end{array}$ & $\begin{array}{r}20 \% \\
18 \% \\
8 \%\end{array}$ & $\begin{array}{r}12 \% \\
7 \% \\
6 \%\end{array}$ \\
\hline 3 & $\begin{array}{r}\text { 2. } 10^{5} \\
10^{5} \\
5.10^{4}\end{array}$ & $\begin{array}{r}1 \% \\
-2 \% \\
-2 \%\end{array}$ & $\begin{array}{l}6 \% \\
5 \% \\
1 \%\end{array}$ & $\begin{array}{r}16 \% \\
4 \% \\
10 \%\end{array}$ & $\begin{array}{l}32 \% \\
26 \% \\
16 \%\end{array}$ \\
\hline 4 & $\begin{array}{r}2.10^{5} \\
10^{5} \\
5.10^{4}\end{array}$ & $\begin{array}{l}2 \% \\
2 \% \\
0 \%\end{array}$ & $\begin{array}{l}4 \% \\
2 \% \\
1 \%\end{array}$ & $\begin{array}{l}60 \% \\
56 \% \\
44 \%\end{array}$ & $\begin{array}{l}58 \% \\
64 \% \\
35 \%\end{array}$ \\
\hline
\end{tabular}


restimulated with irradiated donor leucocytes and tested for cytotoxicity toward donor kidney epithelial cells. A cytotoxicity was found in all four dogs ranging from 4 to $75 \%$ specific lysis (table 1). The data are in accordance with the in vitro data and show that a substantial number of primed precursor CTL do circulate during a first set renal allograft rejection episode.

\subsection{Discussion}

A monolayer adsorption assay has been used to study the affinity of cytotoxic $T$ lymphocytes and their precursors toward stimulator type antigens. Depletion of cytotoxic $T$ cells by adherence on a monolayer of stimulator leucocytes has been reported previously (Bach 1973, Neefe 1976). Our in vitro data show a significant decrease of CTL after adsorption whereas primed precursor CTL do not seem to adhere effectively on leucocyte monolayers. This might implicate that primed precursor CTL do not home in the graft during rejection episodes and might therefore be detectable in the circulation.

We studied the presence of CTL and their precursors in peripheral blood and thoracic duct lymph during first set renal allograft rejections. The inconstant and low direct cell mediated cytotoxicity, which we found during rejection supported the hypothesis of homing of cytotoxic T cells in the graft. Moreover, we detected primed precursor $C T L$ in vivo in all dogs during a rejection episode. These findings support the data on the involvement of CTL in cellular rejection of a kidney allograft. However, our data do not exclude the possibility of DTH cells to be also involved in graft rejection as proposed by Loveland (Loveland 1981).

In respect to immunological monitoring our data might give a possible explanation for the results obtained in clinical transplantation by Stiller. Measuring direct cell mediated cytotoxicity with an assay in which long incubation times of effector and target cells up to 16-18 h were used, he found a good predictive correlation between the presence of circulating CTL and kid ney graft rejection (Stiller 1976). His results might be explained as a maturation of precursor CTL into active cytotoxic T cells during the 16 heffector target cell incubation period. Other investigators who did not use such a long effector target cell incubation time were not able to find a similar consistant correlation of direct cell mediated cytotoxicity and allograft rejection (Grunnet 1978, Kovithavongs 1978).

It remains to be investigated whether the use of kidney epithelial cells as targets for the detection of cytotoxic T cells and their precursors, directed toward MHC and non-MHC antigens is responsible for the high cytotoxicity which we observed.

In clinical transplantation the use of donor kidney epithelial cells as targets for post-transplant monitoring might be an adjuvant test especially in the case of transplantations between MLC negative related donor recipient combinations. The nonlymphoid antigens on kidney epithelial cells might be important for detection of cellular reactivity in such cases. 
It is finally concluded that homing of CTL could be responsible for the inconsistent results of cell mediated cytotoxicity during rejection episodes. A short restimulation of peripheral blood leucocytes gives reliable data about the presence of cell mediated immunity toward donor antigens. Donor kidney epithelial cells as targets might be useful in an adjuvant test for monitoring cell mediated rejection aftertransplantation.

\subsection{Summary}

A monolayer adsorption assay has been used to study the affinity of CTL and their precursors toward stimulator type antigens. It appeared that cytotoxicity could be reduced very effectively with monolayer adsorptions, whereas precursor CTL lack affinity toward stimulator type cellular monolayers. The non-ad herence of precursor CTL toward donor antigens is of great importance in clinical transplantation. The in vitro data of cellular adsorptions have been verified in a canine kidney allograft model in which during first set renal allograft reactions in non-immunosuppressed dogs, the presence of CTL and their precursors was studied. Direct cell mediated cytotoxicity during rejection was observed only marginally in peripheral blood and thoracic duct lymph. Kidney epithelial cells from the donor were used as sensitive targets to detect a cytotoxicity toward lymphoid as well as non-lymphoid antigens. In contrast with the absence of circulating CTL, precursor CTL were detected in all four dogs during the rejection episode. A possible explanation for the inconsistent results of clinical monitoring of cellular cytotoxicity is discussed.

\section{Acknowledgements}

We would like to thank miss Karin Spronck for her excellent secretarial assistance.

This chapter has been submitted for publication.

P.A. Vegt, C.J. van der Linden, A.J.J.M. Daemen, J. Jeekel and W.A. Buurman. Cellular reactivity after transplantation.

\subsection{References}

Ascher NL, Chen S, Hofiman R, Simmons RL. Requirements for the maturation of the cytotoxic effector cells at the allograft site. Transplant Proc $198 \mathrm{y} ; 15 ; 390$.

Ascher NL, Hoffman R, Hanko, DW, Simmons RL. Cellular events within the rejecting allograft. Transplantation $1983 ; 35 ; 193$.

Carpentier B, Lang PH, Martin Bet al. Cells infiltrating rejected human kidney allograft: compositionand in vitro functional capacities. Transplant Proc 1981; 15:84.

Dallman MJ, Mason DW. Role of thymus-derived and thymus-independent cells in murime skin allograft rejection. Transplantation 1982; 33: 221 .

Gowans JL. Knight EJ. The route of recirculation of lymphocytes in the rat. Proc Roy Soc London 1964; 159: 257. 
Kovithavongry "T, Schlaut I, Pardenka $V$ el al. Posteransplant immunologic monitoring with special consideration of technique and interpretation of LMC. Transplant Proc 1978; $10: 547$.

Loveland BE, Hogerth PM, Ceredig RH. Mckenzie IFC. Cells mediangengraft rejection in the mouse. I. Lyil 1 cells mediate skin graft rejection. J Exp Med 1981; 153: 1044.

Loveland BE, McKencie SFC. Which T celis caluse graft rejection? Tramplantation 1982; 33:217.

Neef JR, Sacth DH. Specific elimination of cytotoxic effector cells. I. Adsorptive behavior of effectors and their precursors on spleen cell monolayers. J Exp Med 1976; 144: 996.

Silva A. De Landauri MG, Alvarez J, Kreisler J M. A new method to form target cell monolayers and their use for the immunoadsorpition of cytotoxic effector cells. J Immunol Methods 1978; 23: 303.

Stiller $C R$, Sinclair NR, Abrahams $S$ et al. Antidonor immune responses in prediction of transplant rejection. N Eng J Med 1976; 294: 978.

Tilney N L, Garovoy MR, Busch GJ et al. Rejected thuman renal allografts. Recovery and characteristics of infultrating cells and antibody. Transplantation 1979; $28: 421$.

Vegi PA, Buurman WA, van der Linden CJ, Daemen AJJM, Greep JM, Jeekel J. Cell mediated cytotoxicity toward canine kidney epithelial cells. Transplantation $1982^{\mathrm{A}} ; 33.465$.

Vegt PA, wan der Linden C J, Daemen AJJM., Jeekel J. Buurman WA. Lymphocyte stimulation by canine kidney cells. Transplantation $1982^{b}: 34: 134$.

Willebrand $\mathrm{E}$ von Hâyry $\mathrm{P}$. Composition and in vitro cytotoxicity of cellular infiltrates in rejecting human kidney allografts. Cell Immunol 1978; $41: 358$. 


\section{Chapter 8}

\section{Discussion of the experiments and concluding remarks}

The experiments underiying this thesis were initiated, to investigate whether canine kidney epithelial cells are useful for in vitro studies on cell mediated immunity in transplantation as well as their possible role in clinical transplantation.

\subsection{Cell mediated cytotoxicity toward canine kidney epithelial cells}

In chapter 4 experiments are described in which the presence of target cell antigens on canine kidney epithelial cells has been investigated. It has been well established that non-M HC antigens are involved in kidney transplantation. Kidney graft rejection occurs in a number of HLA identical sibling allografts, despite continuous immunosuppression. The first demonstration of non-M HC antigens in clinical transplantation, concerns the humoral reaction toward end othelial antigens of the donor kidney after transplantation (Paul 1979). These antibodies were present in kidneys of patients who rejected their kidneys and were absent in kidneys removed after transplantation for non-immunological reasons.

Classical mixed leucocyte cultures were performed to generate cytotoxic T lymphocytes, which were tested toward stimulator specific PHA stimulated lymphoblasts as well as kidney cells as targets. Kidney epithelial cells showed to be good and sensitive targets for in vitro stimulated Tlymphocytes. CTL generated in MLC were cytotoxic for ${ }^{51} \mathrm{Cr}$ labeled kidney epithelial cells, identical to the stimulator cell fraction.

To investigate the antigens on these canine kidney cells which are recognized by CTL, adsorption studies of the effector cells have been performed with monolayers of different celltypes. PHA blast monolayers, presenting class I antigens, were not able to reduce all cytotoxicity of CTL toward canine kidney cells. This implicates that a substantial fraction of CTL directed toward kidney epithelial cells recognized antigens other than the class I antigens on these PHA stimulated lymphoblasts. The antigens involved in this kidney epithelial cell specific cytotoxicity, could be tissue specific antigens, class 11 antigens or both. The involvement of a non-class I directed cytotoxicity toward kidney cells was confirmed with cold target inhibition studies with unlabeled PHA stimulated lymphoblasts as cold targets. This resulted in a reduction of only $25 \%$ of cytotoxicity toward kidney epithelial cells where as about $70 \%$ reduction against PHA blast targets was obtained.

A class II directed kill could be very we $\|$ responsible for this phenomenon because class II antigens have been demonstrated on many non-lymphoild cells in several 
species (Tanaka 1979, Mashimo 1976, Sakai 1978). The presence of class II antigens on the kidney epithelial cells has been clearly demonstrated (chapter 5). Also in the human kidney, class II antigens have been demonstrated (Williams 1980). Since a cell mediated cytotoxicity toward class II antigens has been reported by severall investigators (Feighery 1979, Johnson 1980), this class II directed cell mediated cytotoxicity could be responsible for the cytotoxicity observed toward the kidney epithelial cells. Except the class II directed kill also cytotoxicity toward non-lymphoüd antigens could be responsible for the kidney specific lysis. Recently it is de monstrated that an la like antigen is present on circulating $\mathrm{T}$ cells and Con $\mathrm{A}$ induced lymphoblasts in the dog. This favors the concept that the kidney directed cytotoxicity after adsorption on $\mathrm{PHA}$ stimulated lymphoblast monolayers is not directed toward class I or class II antigens, but toward kidney specific antigens. These data favor the hypothesis that our studies indeed demonstrate a non-class I and non-class II but tissue specific antigen directed cytotoxicity toward canine kidney epithelial cells.

The presence of endothelial cells in the kidney cell suspension has been excluded, the possibility that tissue specific antigens, analogous to the endothelial-monocyte antigens as described by Moreas are involved in this kidney directed cytotoxicity still remains a good possibility.

\subsection{Lymphocyte stimulation by canine kidney cells}

A study on the capacity of kidney epithelial cells to ind uce lymphocyte proliferation in vitro has been described in chapter 5 . Bach proposed already in the sixties that the stimulating antigens in the mixed leucocyte reaction could be important in organ transplantation. Lymphocyte proliferation in a mixed leucocyte reaction possibly represents an in vitro analogue of the allograft reaction. A model has been developed in which the unilateral response of lymphocytes toward kidney epithelial cells could be studied. The aim of the study has been to answer the following questions: Are the kid ney epithelial cells capable of inducing allogeneic lymphocyte stimulation. Is the observed lymphocyte proliferation a true immunological reaction toward these kidney cells and not a non-specific transformation of the responder leucocytes.

Dealing with the first question we could exclude carefully contamination of our kidney epithelial cell cultures with other cell types. Culture of the kidney epithelial cells in a D-valine containing MEM medium excluded the growth of fibroblasts. By culturing the cells for at least 15 days and using cells only after three to four passages, the presence of dendritic cells could also be excluded. This is of great importance since dendritic cells are known to be very potent stimulators for leucocytes and are suggested to be responsible for the lymphocyte stimulation observed in mixed kidney leucocyte cultures (MKLC) in the rat (Hart 1981). Extensive studies on dendritic cells revealed that these cells can be kept in culture for only a few days and do not proliferate in vitro, which excludes them from the kidney cell suspensions we used in our stimulation assays. Intracellular immunofluorescence with a highly purified 
anti-F VIII related antigen proved that endothelial cells were not present in the stimulating kidney epithelial cell suspensions.

To investigate the stimulator responder ratios as well as the time response relation in mixed kidney cell leucocyte cultures we performed mixed kidney cell lencocyte cultures in different stimulator responder ratios and measured proliferation of the leucocytes on 5 consecutive days after initiation of the cultures. The time response relation of the mixed kidney cell leucocyte cultures and the mixed leucocyte cultures were identical. Maximal stimulation was obtained on day 6 of the culture, followed by a decrease of proliferation at longer culture times.

Furthermore autologous lymphocytes as well as allogeneic lymphocytes from MHC identical animals have been observed not to be stimulated by kidney cells.

An interesting observation in this study was the low optimal stimulator responder ratio $(1: 20)$ in the mixed kidney cell leucocyte culture compared to an optimal stimulator responder ratio of $1.5: 1$ in the mixed leucocyte culture. Low numbers of kidney cells are potent stimulators whereas a higher concentration of kidney cells showed an inhibitory effect on lymphocyte proliferation. This inhibition could be attributed to specific cell death due to overpopulation or the consumption of $1 L 2$ by the kidney cells.

\subsection{Cellular cytotoxicity generated in a canine mixed kidney lymphocyte cell culture}

The third publication, presented in chapter 6 describes a study on the induction of cytotoxic effector cells by canine epithelial cells. The in vitro generation of cytotoxic $T$ lymphocytes with leucocytes as stimulator cells has been studied extensively. Nonlymphoild cells have been used seldomly for the in vitro generation of CTL. Generation of CTL has been observed in the mice using murine epidermal cell lymphocyte cultures (Steinmuller 1976).

Mixed kidney cell lymphocyte cultures and mixed lymphocyte cultures were performed with cells of one haplotype mismatched beagles. This approach permitted to compare the generation of CTL in both MLR and MKLC. Furthermore the cytotoxic cells generated in a MKLC have been tested for cytotoxicity toward both PHA stimulated lymphoblasts and kidney cell targets. Generation of CTL in mixed kidney cell lymphocyte cultures was observed with stimulator responder ratios of $1: 10$ to $1: 100$. Optimal cytotoxicity was obtained at a $S: R$ ratio of $1: 20$. At $S: R$ ratios below $1: 20$ cytotoxicity has not been observed in MLR. The optimal $\mathrm{S}$ : $\mathrm{R}$ ratio in MKLC for induction of CTL as well as the proliferation of Tlymphocytes was $1: 20$ which is significantly different from the optimal $S: R$ ratio in the mixed leucocyte cullture.

As discussed above this could be attributed to cell death due to overpopulation or due to the consumption of $1 L 2$ by the kidney cells. The data presented in this thesis are in accordance with those of Steinmuller (1976) who showed generation of CTL by allogeneic murine epidermal cells and with Daniel (1975) who described the destruc- 
tion of kidney cell monolayers after generation of CTL in mixed kidney cell leucocyte cultures. The antigens recognized by the CTL generated in a MKLC have to be further investigated.

We demonstrated in a MLC that CTL are generated, which show cytotoxicity for PHA blasits and kidney cells as well as for antigens present on kidney epithelial cells, which were not present on PHA blasts. The question whether the population of CTL clones generated in a mixed kidney cell leucocyte culture do differ significantly from CTL generated in a mixed leucocyte culture has not yet been answered. Further studies under limiting dillution conditions have to be carried out, to reveal this question and to compare the different clones generated in MKLC and MLR respectively.

\subsection{Cellular reactivity after transplantation}

Many in vitro tests are available for monitoring the cellular and humoral immune status of the recipient after transplantation. The detection of circulating cytotoxic T lymphocytes after transplantation remains a great problem in clinical transplantation. A possible explanation of the absence of circulating CTL after transplantation may be the adherence of these CTL at donor antigens in the transplanted kidney.

The experiments presented in chapter 7 concern two studies. First the adherence of CTL and their precursors on stimulator antigens has been studied. Secondly the results of this study have been evaluated in an in vivo model of kidney transplantation in the dog.

Stimulated T lymphocytes generated in a mixed leucocyte reaction were tested for cytotoxicity and their adherence at stimulator antigens on day 3, 4, 5 and 6 of the initial culture. Cytotoxicity has been observed on day 4,5 and 6 of culture, with a maximal value at day 6. Cytotoxicity was reduced for $80-90 \%$ after adsorption on stimulator type leucocyte monolayers. This indicates that the CTL present in these cell fractions do adhere to stimulator antigens in vitro, analogous to the donor antigens in vivo.

The presence of primed precursor CTL in the non-adherent cell fractions was studied with restimulation studies. The results of these experiments clearly showed that non-adherent cell fractions after adsorption are rich in primed precursor cytotoxic $T$ cells. This indicated that primed precursor cytotoxic $T$ cells do not adhere to tudies. Direct cell mediated cytotoxicity of peripheral blood lymphocytes as well as thoracic duct lymphocytes has been studied in dogs during a first set rejection episode. With a normal 6 hours incubation time of effector and donor target cells using the ${ }^{51} \mathrm{Cr}$ release assay, only a marginal cytotoxicity in the dogs during a serious rejection episode could be detected.

We demonstrated the presence of circulating precursor CTL in dogs during a rejection episode after transplantation. This supports the data on the involvement of CTL in cellular rejection. The inconsistent and low direct cell mediated cytotoxicity detected in peripheral blood and thoracic duct lymph favors the hypothesis of homing 
of CTL in the transplanted kidney. Graft infiltrating cells during rejection have been shown to be CTL which give direct cell mediated cytotoxicity.

These data do not exclude the possible involvement of cells involved in delayed type hypersensitivity reactions (DTH cells) in cellular rejection as proposed by Loweland. The data obtained in this study could explain the results presented by Stiller who showed a direct cell mediated cytotoxicity which correlated with the onset of rejection. Stiller performed direct cell mediated cytotoxicity tests with 16-18 hours incubation times of the effector and target cells, instead of the usual 6 hours incubation time. The direct cytotoxicity which he observed could be explained by the maturation of circulating precursor CTL during the $16-18$ hours in vitro culture.

It is concluded that the experiments presented in this thesis give a positive answer about the usefulness of kidney epithelial cells for in vitro studies of cell mediated immunity. Stimulation experiments showed clearly the presence of lymphocyte stimulating (class II) antigens on canine kidney epithelial cells, whereas the cytotoxicity studies presented in chapter 4 do indicate the presence of class 1 , class 11 and organ specific antigens on the canine kidney epithelial cells. The last publication presents a new assay for in vitro monitoring of precursor CTL after transplantation, which with the use of donor kidney cells as targets, offers the possibility to detect cell mediated cytotoxicity after transplantation directed toward class I, Class II and organ specific antigens. 



\section{Summary}

To achieve a successful kidney transplantation, many problems in respect to the immunological phenomenon of rejection have to be solved. Appropriate selection of donor and recipient can diminish the number of antigens to which a rejection can be initiated. Performing crossmatches of the recipients serum with donor antigens before transplantation can detect a state of pre-sensitization of the recipient toward donor antigens. Pre-sensitization is likely to be associated with an acute rejection in a number of cases, pre-transplant monitoring is therefore of great clinical importance.

Donor recipient selection is determined by matching for leucocyte antigens, which belong to the Human Leucocyte Antigen (HLA) system. It is well established that also non-HLA antigen systems exist in man. The involvement of non-HLA antigens in kidney transplantation has recently been proven. Antibodies directed toward endothelial antigens of the donor in patients rejecting their kidneys have been detected, while these antibodies were absent in kidneys removed after transplantation for non-immunological reasons.

The existence of non-leucocyte antigens and their involvement in kidney transplantation were a motive to study antigens on canine kidney epithelial cells. The studies on cell mediated immunity toward canine kidney epithelial cells, which form the base of this thesis are presented in four publications.

The first publication as presented in chapter 4 describes a study on cell mediated cytotoxicity toward kidney target cells. Monolayer adsorption studies have been performed to study whether CTL recognize identical antigens on kidney epithelial cells as on PHA stimulated lymphoblasts. Cytotoxicity toward PHA stimulated lymphoblasts has been reduced by leucocyte and kidney cell monolayers, whereas leucocyte monolayers reduced cytotoxicity toward kidney epithelial cells for only $40 \%$. These results and cold target inhibition data strongly suggest that kidney epithelial cells present antigens to which a selective population of CTL is directed. It is discussed whether the relevant antigens on the kidney cells are organ specific antigens or MHC antigens not present on PHA blasts.

Chapter 5 deals with the question whether antigens on kidney epithelial cells are capable to induce proliferation of allogeneic or syngeneic lymphocytes. In the in vitro model of the mixed kidney cell leucocyte culture, the kidney cells appeared to be strong stimulators in an allogeneic stimulator responder combination. Maximal proliferation responses have been observed at a $S: R$ ratio of $1: 20$. At this low $S: R$ ratio no stimulation was observed in a mixed leucocyte reaction. Lymphocyte stimulation has not been observed in mixed kidney leucocyte cultures between MHC identical closely bred animals. 
To investigate whether the kidney epithelial cells were the true stimulators in the mixed kidney leucocyte cultures, contamination with other cells had to be excluded carefully. The use of a selective medium, containing D-valine instead of $L$-valine permitted only the growth of epithelial cells. Fibroblastoid cells which are unable to convert the $\mathrm{D}$-valine into the essential $\mathrm{L}$-valine are not capable to survive in a D-valine containing medium. Intracellular immunofluorescence with anti-factor VIII anti-serum showed that contamination of the cell cultures with endothelial cells was absent. Contamination with dendritic cells could be excluded by culture of the kidney cells for at least 15 days before they were used as stimulators. It has been concluded that kidney epithelial cells are strong stimulators for allogeneic lymphocytes; the nature of the antigens responsible for this stimulation has been discussed.

The ability of kidney cells to ind uce cytotoxic T lymphocytes (CTL) after allogeneic stimulation has been studied and described in the third publication. Generation of CTL, cytotoxic for both kidney cells and PHA stimulated lymphoblasts, has been observed in mixed kid ney cell leucocyte cultures. Lymphocyte stimulation and generation of CTL occurred in the MKLC at lower stimulator responder ratios than in the mixed lymphocyte culture. These data are in accordance with those of Steinmuller, who observed generation of CTL in mixed murine tail epidermal cell lymphocyte cultures. The results are not in agreement with Lafferty's model of 'immunogenicity of foreign tissues* because in our experiments CTL are generated in the absence of lymphoid cells in the stimulator cell fraction.

The first three publications clearly showed that canine kidney epithelial cells are useful for in vitro studies toward non-MHC antigens. Their possible use in studies on cell mediated immunity after transplantation has been investigated in chapter 7 .

An adsorption model in which primed $\| y$ mphocytes were adsorpted on stimulator le ucocyte monolayers has been used to study the affinity of CTL and their precursors toward donor antigens. The results of immunoadsorption assays performed during the generation of CTL clearly show that primed precursor CTL do lack affinity toward stimulator type antigens. When this is extrapolated to the clinical situation, it might implicate that primed precursor CTL do not adhere toward donor antigens in the grafted kid ney. Precursor CLT are thus expected to circulate after transplantation during cellular rejection and can be detected in peripheral blood. This is of great clinical importance since the detection of CTL in peripheral blood still gives inconsistent results, probably due to the homing properties of the CTL in the grafted kidney.

In a canine kidney transplantation model in which no immunosuppression was given, CTL and their precursors were studied in peripheral blood and thoracic duct lymph during first set rejection episodes. Circulating CTL could only be detected marginally in dogs during a severe first set rejection episode. A short restimulation of leucocytes from the identical samples of peripheral blood and thoracic duct lymph revealed that they were rich in primed precursor CTL in all dogs during this rejection episode. This finding supports the data on the involvement of CTL in cellular allograft rejection. The canine kidney epithelial cells of the donor kidney served as sensitive targets for this cell mediated cytotoxicity after transplantation. 
These studies show that kidney epithelial cells carry antigens which are target antigens for in MLC generated cytotoxic T cells and not present on PHA stimulated lymphoblasts. Kidney epithelial cells were able to stimulate allogeneic lymphocytes in lower stimulator responder ratios than leucocyte stimulator cells. A stimulation in a MKLC between MHC identical animals however was not observed. This implies that for lymphocyte proliferation by kidney epithelial cells still a difference in $\mathrm{MHC}$ antigens is required. When kidney epithelial cells are used for in vitro monitoring after transplantation they can detect a cellular reactivity toward lymphoid and non-MHC antigens during rejection episodes. 

Voor het doen slagen van een niertransplantatie moeten vele problemen op het gebied van de immunologische afweer worden opgelost. Een juiste selectie van donor en ontvanger leidt tot een vermindering van het aantal transplantatie-antigenen, die bij de ontvanger een afstotingsreactie kunnen induceren. Kruisproeven van ontvangerserum met donorlymfocyten kunnen circulerende antilichamen bij de ontvanger aantonen, die gericht zijn tegen de antigenen van de donor. Gezien het feit dat sensibilizatie van de ontvanger tegen donorantigenen in een aantal gevallen gepaard gaat met een versnelde afstotingsreactie is het van groot belang potentiele niertransplamtatiepatiënten op de aanwezigheid van dergelijke tegen donorantigenen gerichte antilichamen te onderzoeken.

Het selecteren van de donor en ontvanger gebeurt aan de hand van antigenen welke behoren tot het Humane Leucocyten Antigeen (HLA-) systeem. Recent is aangetoond dat ook andere antigenen, welke niet tot het HLA-systeem behoren, een rol spelen bij de afstoting van niertransplantaten. Bij patiënten die hun nier hadden afgestoten werden antilichamen aangetoond, welke gericht waren tegen antigenen aanwezig op de endotheelcellen van de ontvangen nier. Deze antilichamen werden niet gevonden in de nieren van mensen bij wie de getransplanteerde nier om andere redenen moest worden verwijderd.

De aanwezigheid van deze antilichamen gericht tegen niet tot het HLA-systeem behorende antigenen bij afstotingsreacties van de nier was aanleiding tot het onderzoek naar de antigenen die aanwezig zijn op nierepitheelcellen. De cellulaire immuniteit tegen antigenen op nierepitheelcellen werd onderzocht. De resultaten van dit onderzoek zijn beschreven in 4 publicaties, welke de kern vormen van dit proefschrift.

De eerste publicatie beschrijft een model waarin de cellulaire cytotoxiciteitsreacties tegen in vitro gek weekte hondenierepitheelcellen worden bestudeerd. Met behulp van celluläre immuun adsorptietechnieken werd onderzocht of er op nierepitheelcellen target-antigenen aanwezig zijn welke als zodanig door cytotoxische T-lymphocyten herkend kunnen worden. Tevens werd bestudeerd of deze antigenen ook op hondeleucocyten aanwezig zijn.

$\mathrm{Na}$ adsorptie van de effectorcellen (= cytotoxische T-lymphocyten) op leucocytenen niercelmonolayers verdween de cytotoxiciteit voor PHA-gestimuleerde lymphocyten wrijwel geheel. Leucocyten-monolayers waren echter niet in staat alle effectorcellen uit te adsorberen, welke gericht waren tegen target-antigenen op de niercellen. Hieruit werd geconcludeerd dat er een subpopulatie van cytotoxische T-cellen bestaat welke antigenen herkent op niercellen, die niet aanwezig zijn op leucocyten. Dit werd bevestigd met behulp van cytotoxiciteitsremmingstesten. In de 
discussie wordt ingegaan op de vraag of deze antigenen behoren tot het MHC-complex of dat er sprake is wan weefselspecilleke antigenen.

In de tweede studie werd onderzocht of nierepitheelcellen in staat zijn tot het stimuleren van allogene en syngene leucocyten. Hierwoor werd het model van de gemengde niercel-leucocytenkweek gebruikt. Gemengde kweken van niercellen en leucoeyten met verschillende verhoudingen tussen de stimulator en responder toonden aan dat de nierepitheelcellen in significant lagere aantallen dan leucocyten, stimulatie gaven van allogene leucocyten. Er werd geen stimulatie van MHC-identieke leucocyten gevonden door nierepitheelcellen. Een belangrijk aspect van leucocytenstimulatie door niet-lymphoide cellen is de eventuele verontreiniging van deze niet-lymphoide stimulatorcellen met andere celtypen. Om deze mogelijk heden uit te sluiten werd er uitgebreid onderzoek gedaan naar de morfologische en functionele eigenschappen van de nierepitheelcellen, welke gebruikt werden voor de stimulatieproeven.

Verontreiniging met endotheelcellen kon worden uitgesloten door middel van immunofluorescentie met antifactor-VIII antiserum. Dit reageert specifiek met endotheelcellen en de stimulator-celsuspensies bevatten geen cellen met significante immunofluorescentie. Het gebruik van een speciaal kweekmedium waarin het essentiële aminozuur $\mathbb{L}$-valine was vervangen door $\mathrm{D}$-valine, voorkwam de groei van fibroblasten in de nierepitheelcelkweken. De aanwezigheid van dendritische cellen, welke bekend staan om hun sterk leucocyten-stimulerende eigenschappen, kon worden uitgesloten door de nierepitheelcellen minimaal twee weken te kweken voordat ze gebruikt werden als stimulatorcellen.

De mogelijkheid dat nierepitheelcellen behalve lymphocyten-proliferatie ook het ontstaan van cytotoxische T-lymphocyten kunnen ind uceren, werd onderzocht in een studie welke in hoofdstuk zes wordt beschreven. Stimulatie en inductie van cytotoxische T-cellen vond plaats in gemengde nierepitheelcel-leucocytenkweken. Een lagere stimulator-responder celverhouding dan in de conventionele gemengde leucocytenkweken leidde tot optimale generatie van CTL.

Uit het voorgaande is duidelijk gebleken dat de hondenierepitheelcellen zich goed lenen voor het bestuderen van cellulaire afweerreacties tegen niet door het MHCgecodeerde antigenen.

Hoofdstuk zeven beschrift een in vitro stud"e naar affiniteit van gestimuleerde precursor-cytotoxische T-cellen voor stimulator-antigenen. Tevens wordt in een in vivo transplantatiemodel de bruikbaarheid van de hondeniercel voor monitoringdoeleinden onderzocht. Directe cytotoxiciteit kon slechts minimaal worden aangetoond. Wel kon door middel van restimulatie worden aangetoond dat er precursorcytotoxische T-cellen circuleerden tijdens de afstotingsreactie. Dit werd in alle honden gevonden. Doordat in dit monitoringmodel nierepitheelcellen van de donorhond werden gebruikt voor het aantonen van de cellulaire afweer, kon met behulp van de restimulatiestudie de aanwezigheid van een cellulaire reactie tegen zowel lymphoide als orgaanspecifieke antigenen worden aangetoond.

De onderzoekingen welke ten grondslag lagen aan dit proefschrift hebben aangetoond dat de nierepitheelcellen van de hond zeer geschikt zijn voor het bestuderen van 
cellulaire immuniteit tegen orgaanspecifieke antigenen. De nierepitheelcellen bezitten antigenen die door cytotoxische $\mathrm{T}$-cellen herkend worden. Tevens kunnen nierepitheelcellen leucocyten stimuleren to proliferatie in een gemengde niercel-leucocytenkweek. Ook werden in deze niercel-leucocytenkweken cytotoxische T-cellen gestimuleerd. Het gebruik van nierepitheelcellen bij de immunologische monitoring na transplantatie geeft de mogelijkheid cellulaire reactiviteit tegen lymphoide als ook tegen orgaanspecifieke antigenen aan te tonen. 

Het op de voorpagina van een proefschrift noemen van éen naam is misleidend; dit boekje is tot stand gekomen met de hulp van velen welke ik op deze plaats graag wil bedanken voor alle medewerking gedurende de afgelopen jaren.

Hooggeleerde Jeekel, geachte promotor, je bood mij de gelegenheid om gedurende twee jaar het wetenschappelijk onderzoek te doen welke uiteindelijk tot dit proefschrift heeft geleid.

Hooggeleerde Greep, geachte promotor en opleider, niet alleen je bekende dynamiek en stuwende kracht, welke reeds tot vele zilvergrijze boekjes hebben geleid, maar vooral je stimulatie en persoonlijke interesse tijdens de uren dat we samen het manuscript bij je thuis doorwerkten, zullen als een goede herinnering blijven bestaan.

Zeergeleerde Buurman, beste Wim, je bent niet alleen mijn leermeester die een groot deel van de studies voor dit proefschrift ontwierp, je bent vooral een zeldzame combinatie van een basalwetenschapper met een uitgebreide interesse in het klinisch handelen. Dank voor al het geduld en de tijd die je ook s' avonds altijd had om dit proefschrift af te maken.

Dr Van der Linden, beste Cees, vanaf het begin van dit onderzoek heb je altijd met veel inzet en interesse meegedaan en jouw analyserend vermogen hebben - dankzij onze discussies en correcties - veel aan dit proefschrift bijgedragen.

Dit proefschrift bestaat voor het grootste gedeelte uit 'in vitro'-studies. Het zijn dan ook Ineke Daemen en Trudy Jeunhomme geweest die mij niet alleen het laboratoriumwerk geleerd hebben, maar ook met enthousiasme een groot deel van het werk voor hun rekening hebben genomen.

De operaties bij de honden zijn op vakkundige wijze ondersteund door het Centraal Proefdieren Laboratorium en de Caviciteitsgroep Fysiologie. Huub Simons heeft buiten de operatiekamer uitstekend voor de honden gezorgd.

The job is not finished after the paperwork has done. Het zijn dan ook Marcia Steegmans van Puijenbroek, Marijke van den Berg, Maartje Duyzings en Karin Spronck dankzij wie het uiteindelijk gelukt is om alles zwart op wit in de 'Digital' te krijgen. Vooral Karin will ik bedanken voor het feit dat zij de laatste maanden minstens tien maal mijn definitieve versie definitief heeft gemaakt met nieuwe verbeteringen.

Mijn medeassistenten van de afdeling Algemene Heelkunde hebben steeds ingevallen wanneer er weer aan het proefschrift gewerkt moest worden. Henk Jas heeft er voor gezorgd dat de inhoud van de 'Digital'-floppy disc op tijd via de centrale computer per telefoon naar Krips Repro werd werzonden, waar dit proefschrift snel en vakkundig zijn uiteindelijke vorm heeft gekregen. 
Dr Allan Vafi en Chrys Steegmans hebben een persoonlijke noot aan dit proefschrift gegeven, door respectievelik mijn curriculum vitae te tekenen en het omslag te voorzien van Chucky, Titi en Negra.

Dr Chris Lawrence, dank voor je leerzame adviezen wat betreft de Engelse spelling.

Lieve Dushi, je bent op jouw geheel eigen wijze een enorme stimulans geweest bij de baring van dit proefschrift; nu de volgende...

Tenslotte Pa en $\mathrm{Ma}$, jullie levenskunst en relativerend vermogen zijn een grote steun geweest bij de bekende momenten van stress tijdens het afmaken van dit proefschrift.

Paul Vegt 


\section{Curriculum vitae}

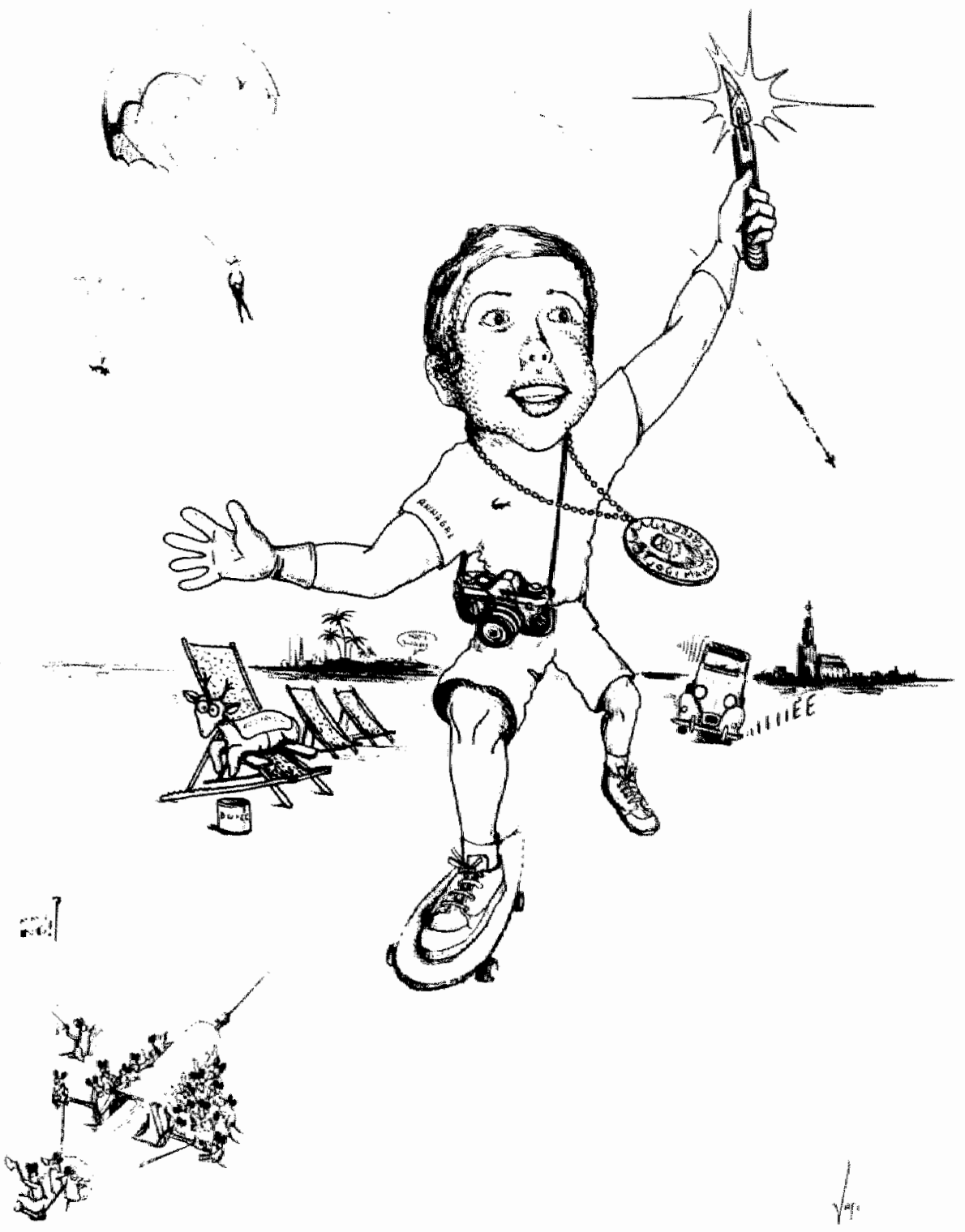

19-10-1952 Geboren te Zoetermeer.

1969 Eindexamen HBS-B aan het Huygens Lyceum te Voorburg.

1977

Artsexamen aan de Rijksuniversiteit te Groningen.

1980

Aanvang opleiding Algemene Heelkunde in het Ziekenhuis

St. Annadal te Maastricht; opleider J. M. Greep. 